\title{
CELL CYCLE DYNAMICS AND THE \\ PHYSIOLOGY OF SAXITOXIN BIOSYNTHESIS IN \\ Alexandrium fundyense (DINOPHYCEAE)
}

By

Gaspar Taroncher Oldenburg

'Licenciado', Universidad Autónoma de Madrid, Spain

SUBMITTED IN PARTIAL FULFILLMENT OF THE REQUIREMENTS FOR THE DEGREE OF

\section{DOCTOR OF PHILOSOPHY}

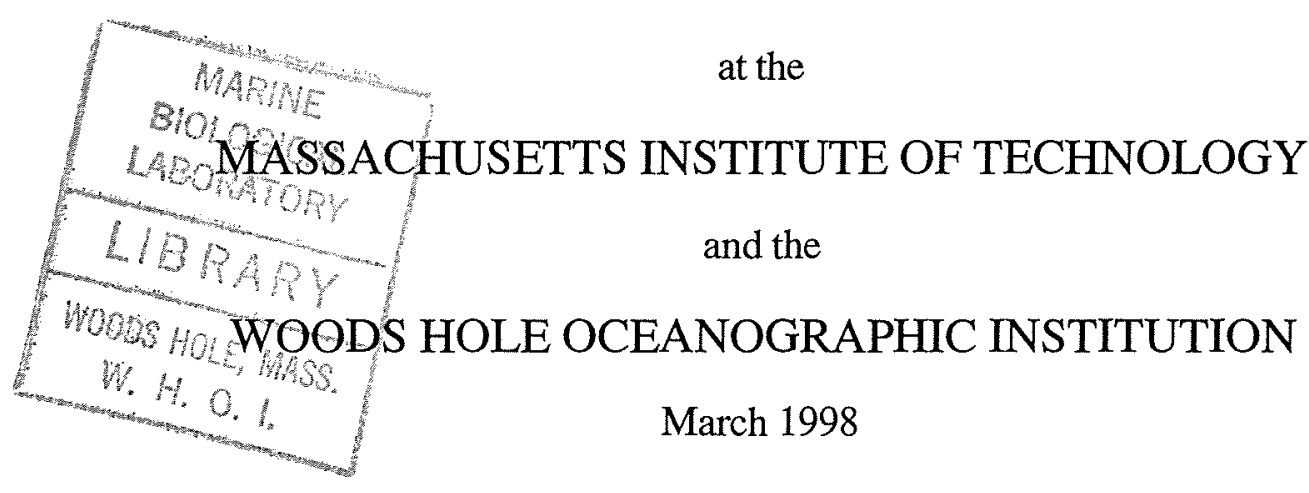

(C) 1998 Gaspar Taroncher Oldenburg All rights reserved

The author hereby grants to MIT and WHOI permission to reproduce paper and electronic copies of this thesis in whole or in part, and to distribute them publicly.

Signature of Author

Joint Program in Biology, Massachusetts Institute of Technology/ Woods Hole Oceanographic Institution

Certified by

Donald M. Anderson Thesis Supervisor

Accepted by

Mark E. Hahn Chairman, Joint Committee for Biology Massachusetts Institute of Technology/ Woods Hole Oceanographic Institution 


\section{TABLE OF CONTENTS}

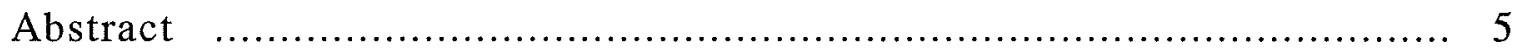

Introduction Saxitoxins in dinoflagellates: origin, physiology and molecular biology

Chapter I Toxin variability during the cell cycle of the dinoflagellate Alexandrium fundyense

Chapter II Coupling of saxitoxin biosynthesis to the $\mathrm{G}_{1}$ phase of the cell cycle in the dinoflagellate Alexandrium fundyense: temperature and nutrient

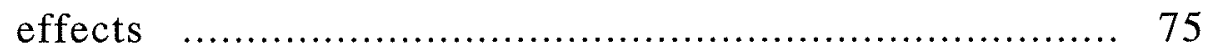

Chapter III Identification and characterization of up- and downregulated genes during saxitoxin biosynthesis in Alexandrium fundyense (Dinophyceae)

Appendix

Cloning and characterization of a putative histone-like protein in Alexandrium fundyense (Dinophyceae) 


\title{
Cell cycle dynamics and the physiology of saxitoxin biosynthesis in Alexandrium fundyense (Dinophyceae)
}

by

\section{Gaspar Taroncher Oldenburg}

Submitted in partial fulfillment of the requirements for the degree of

Doctor of Philosophy

\begin{abstract}
The mechanism of saxitoxin (STX) biosynthesis in marine dinoflagellates of the genus Alexandrium is still unknown. The aim of this thesis was to analyze novel aspects of toxigenesis during the cell cycle in Alexandrium and to apply molecular techniques to gain new insights on the genetics and regulation of STX biosynthesis.

Synchronized cultures of $A$. fundyense were studied to determine the dynamics of toxin production throughout the cell cycle. Toxin production was discontinuous, was induced by light and always occured during a period of approximately eight to ten hours in early $\mathrm{G}_{1}$. Analysis of the cell cycle dynamics suggests the existence of two transition points: one at the beginning of $G_{1}$, which is light-dependent and holds the cells in a $G_{0}$-like period, and a second one at the end of $\mathrm{G}_{1}$, which is size-dependent and arrests the cells in $\mathrm{G}_{1}$. A model of the cell cycle of $A$. fundyense is proposed in which progression through the cell cycle can be arrested at two different transition points located in $G_{1}$ and toxin production is induced by light during $\mathrm{G}_{1}$.
\end{abstract}


The effects of temperature and phosphate limitation on the linkage between changes in the duration of the cell cycle stages and toxicity were studied in semi-continuous cultures of A. fundyense. A direct correlation between $\mathrm{G}_{1}$ duration and toxin content was observed, along with a clear uncoupling of toxin accumulation from the $S$ and $G_{2}$ phases of the cell cycle. In both experiments, toxin production rates remained constant for the respective range of conditions, implying that the variations in toxin content observed were a result of increasing periods of biosynthetic activity. Phosphate limitation enhanced toxin production rates and affected interconversions among STX derivatives in several ways: oxidations to yield the hydroxy-series of STXs were phosphate-dependent while sulfatation reactions were not.

Differential Display (DD) analysis was applied to the identification of genes that were up- or downregulated during toxigenesis in synchronized cultures of $A$. fundyense. Three genes were isolated: $S$-adenosylhomocysteine hydrolase, methionine aminopeptidase and a histone-like protein. None could be directly correlated to toxigenesis but instead relate to general cellular metabolism. 


\section{INTRODUCTION}

Saxitoxins in dinoflagellates:

Origin, physiology and molecular biology 
The increase in occurrence of harmful algal blooms and their rapid dispersal into new areas of the world over the past decades has prompted research aimed at describing this phenomenon and ultimately understanding the biological and evolutionary significance of toxin production by phytoplankton. The division Dinoflagellata (Greek dinos, whirling) (Fensome et al., 1993), includes some of the geographically most widely distributed species of toxic microalgae. Some of the common characteristics of these toxic dinoflagellates are bi-flagellation, a permanently condensed nucleus, a neritic or estuarine distribution, and the production of toxic secondary metabolites (Taylor, 1987).

One of these groups of compounds comprises saxitoxin (STX), a positively charged perhydropurine alkaloid, and its over twenty known derivatives (Fig.1) (Shimizu, 1993). STX is a potent neurotoxin that actively blocks $\mathrm{Na}^{+}$-channels and consequently causes paralysis of the neuromuscular system (Narahashi, 1988; Lipkind and Fozzard, 1994), resulting in a symptomatology called Paralytic Shellfish Poisoning (PSP) (Meyer et al., 1928). PSP outbreaks occur in littoral waters throughout the world and have a major impact on public health and industry (Anderson, 1989). Their effects range from marine mammal, fish and seabird mortality to human intoxication and fatalities as a result of ingesting contaminated shellfish or fish (Geraci et al., 1989; Shumway, 1990). PSP toxins also induce alterations of the marine trophic balance through adverse effects on larvae and other life history stages of fisheries species (White et al., 1989; Montoya et al., 1996).

\section{ORIGIN OF SAXITOXIN}

PSP was first related to a planktonic dinoflagellate in the genus Gonyaulax in 1937 (Sommer et al., 1937). It was proposed that the toxic phytoplanktonic cells were ingested by filter-feeders that were not affected by the active compounds, resulting in a net 
accumulation of STX and amplification of the toxicity toward higher elements of the food chain. Since then, other species of dinoflagellates in the genera Alexandrium (=Gonyaulax, Protogonyaulax) (Schantz et al., 1975; Cembella et al., 1987; Steidinger and Moestrup, 1990), Pyrodinium (Maclean, 1973; Harada et al., 1982) and Gymnodinium (Estrada et al., 1984; Oshima et al., 1987) have been shown to also produce saxitoxins. In addition to these dinoflagellates, several other microorganisms such as the cyanobacteria Aphanizomenon flos-aquae and Anabaena circinalis and the bacteria Moraxella sp., Bacillus sp., Acinetobacter sp. and Pseudomonas sp. are also able to synthesize saxitoxins (Alam et al., 1978; Kodama et al., 1988; Ogata et al., 1990; Humpage et al., 1994; Franca et al., 1996; Levasseur et al., 1996). However, toxin production by bacteria remains a controversial issue. A variety of methods, including HPLC, mouse neuroblastoma assay and ELISA, have been used to determine the presence of STX in bacteria, but unequivocal proof by mass spectrometric analysis is still needed to confirm the chemical structure of the compounds involved (Gallacher et al., 1996).

The fact that some of the above mentioned bacteria can be found in close association with dinoflagellates, either as endosymbionts or extracellularly, has raised a controversy on their possible role in the production of toxins generally attributed to the dinoflagellates (Rausch de Traubenberg and Lassus, 1991). This so called 'Bacterial Hypothesis' has been substantiated by a suite of observations. The presence of intracellular bacteria in Alexandrium and their role in STX production were first documented in 1982 (Silva, 1982; Singh et al., 1982). Detection of STX in the water column in the absence of dinoflagellates has been correlated to the presence of bacteria in the genera Moraxella, Pseudomonas, Aeromonas and Acinetobacter (Kodama et al., 1990; Sakamoto et al., 1992; Levasseur et al., 1996). Laboratory studies with two bacteria isolated from Alexandrium cultures, Moraxella sp. and Pseudomonas sp., have shown that saxitoxin accumulation patterns under nutrient stress in bacteria follow similar trends to those observed in the dinoflagellate 
Fig. 1 Structures of the saxitoxin (STX) and neosaxitoxin (NEO) series of toxins. (NEO is the 1- $N$-hydroxy derivative of STX (OH underlined)). The basic structure, 13-deoxy-decarbamoyl-STX, is determined by atoms 1 to 13 (compare Fig. 3; STX is the 6-carbamoyl derivative of 13-deoxy-decarbamoyl-STX (see text)). $\mathbf{R}_{1}$ represents the 11- $\beta(\alpha) O$-sulfatation site, $\mathbf{R}_{\mathbf{2}}$ represents the 13hydroxy, 13-O-carbamoyl or $\mathrm{N}$-sulfo-13-O-carbamoyl substitution site. 

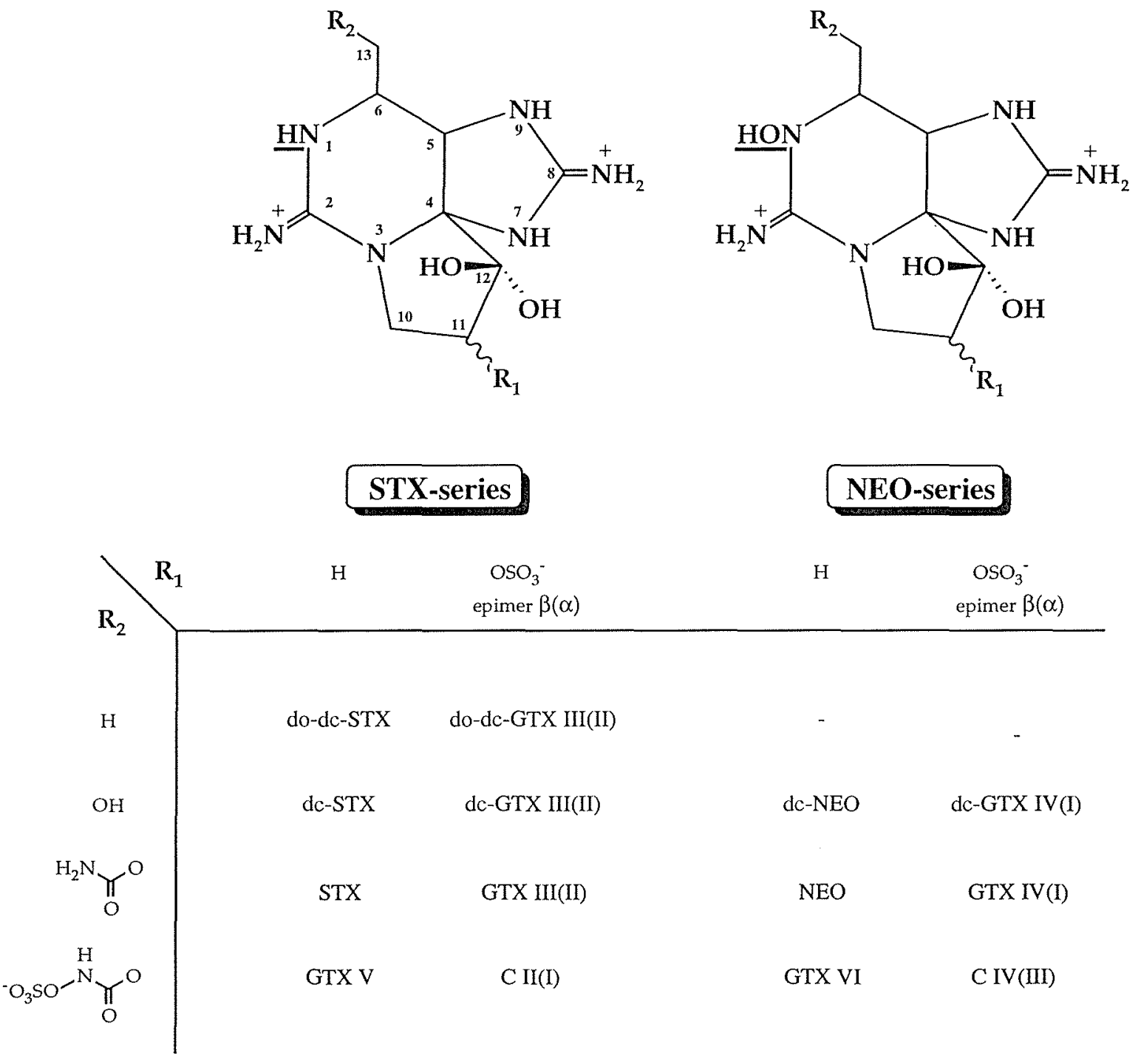
under similar limiting conditions (Kodama, 1990; Doucette and Trick, 1995; Franca et al., 1996). However, in none of the documented cases of putative toxin production by bacteria did the toxin levels measured reach values that could account for toxin concentrations typically observed in bloom situations or in culture (Gallacher et al., 1996). Moreover, toxin production in axenic dinoflagellate cultures has been widely demonstrated (Singh $e t$ al., 1982; Boczar et al., 1988; Kim et al., 1993), while addition of Moraxella to Alexandrium tamarense cultures has also been observed to result in an actual decrease in toxicity of the dinoflagellate (Ogata et al., 1996). One additional argument against the bacterial hypothesis comes from dinoflagellate cyst mating experiments which suggest that inheritance of both the ability to synthesize toxin and the toxin profiles themselves follows a 1:1 segregation pattern for the F1 generation. This rules out a direct involvement of bacteria in the process, as this would result in a random distribution of toxic phenotypes in the F1 generation (Oshima et al., 1993; Oshima, 1995). All this evidence suggests that both bacteria and dinoflagellates, as well as cyanobacteria, are capable of producing saxitoxin but the scope of their interactions and the evolutionary process underlying the acquisition of this capability remain to be clarified.

\section{BIOCHEMISTRY OF SAXITOXIN}

Over 4,000 alkaloids have been described in organisms throughtout the different kingdoms and extensive work has been done on elucidating their possible precursors and putative anabolic pathways (Leete, 1969). Saxitoxin is a positively charged, perhydropurine-like alkaloid. Saxitoxin derivatives represent different combinations of 1$N$-hydroxy, 11- $\alpha$ - $\beta$-O-sulfate, 13-hydroxy, 13-O-carbamoyl and $N$-sulfo-13-O-carbamoyl substitutions of the basic skeleton, 13-deoxydecarbamoyl-STX, that cover a broad range of 
toxicities depending on their affinity to $\mathrm{Na}^{+}$-channels (Fig. 1) (Hall, 1982; Shimizu, 1993). A putative biosynthetic pathway for STX has been proposed following a series of feeding experiments with labeled compounds (Shimizu, 1993). Given the purine-like structure of STX, a first approach consisted in providing the dinoflagellate Gonyaulax catenella (=Alexandrium catenella) with known precursors of the purine biosynthetic pathway, but no labeling of STX was observed (Proctor et al., 1975). Further attempts to use dinoflagellates for these studies were hampered by the cell's autotrophic nature, which makes them incapable of directly utilizing exogenous organic molecules, thus making it impossible to trace the fate of labeled compounds supplied externally (Shimizu et al., 1984). Consequently, another organism, the cyanobacterium Aphanizomenon flos-aquae was used for feeding experiments and other precursors were tried until it was eventually determined that the perhydropurine skeleton of STX incorporates one molecule each of the basic aminoacid arginine (Arg) and acetate, one methyl group from methionine, via $S$ adenosyl methionine, and three guanido/ureido groups derived from Arg (Shimizu et al., 1984). This incorporation pattern precluded a purine origin of the perhydropurine-like skeleton of STX. Based on the above scheme, a new biogenetic pathway was proposed, consisting of a Claisen-type condensation of Arg and an acetate molecule, followed by transamidination of a guanido group from a second molecule of Arg with subsequent cyclation and methylation at the C-6 position (Fig 2) (Shimizu, 1993).

The sequence of transformations among derivatives can only be inferred from indirect evidence. Predominance of $11-\beta$-epimers (GTX III, GTX IV, C2 and C4) over $11-\alpha$ epimers (GTX I, GTX II, C1 and C3) suggests that only $11-\beta$-epimers are synthesized in Alexandrium and Gymnodinium and that the presence of 11- $\alpha$-epimers is a result of postsampling, in vitro epimerization (Hall et al., 1990; Oshima et al., 1993). Characterization of several $N$-sulfotransferases in these two species that use exclusively $1-N$-dehydroxy 
Fig. 2 Biogenetic pathway proposed for the biosynthesis of STX (reviewed by Shimizu, 1993). Labeling studies were performed with the dinoflagellate Gonyaulax catenella (=Alexandrium catenella) and the cyanobacteria Aphanizomenon flos-aquae. Arginine, acetate and $S$-adenosyl-methionine (SAM) have been shown to be the direct precursors of STX. 

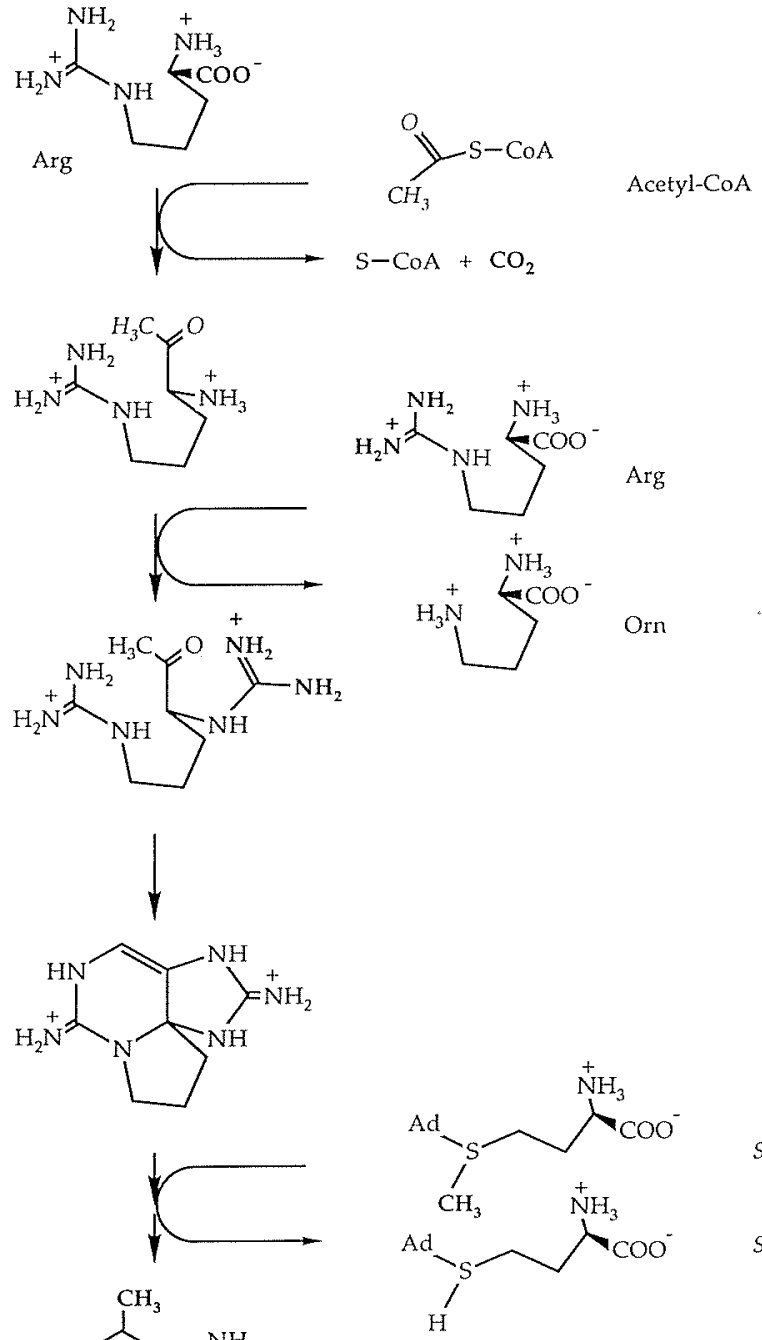

S-Adenosyl-Methionine

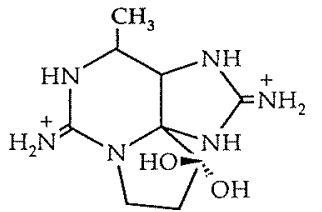

S-Adenosyl-Homocysteine

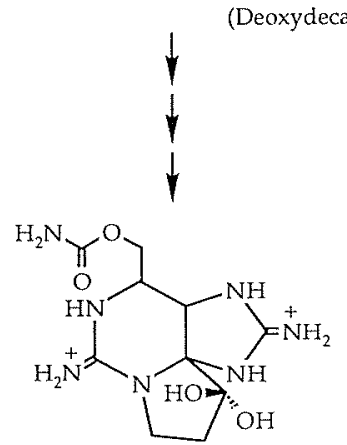

STX 
derivatives as substrates (GTX II, GTX III and STX) (Oshima, 1995; Yoshida et al., 1996), and the observation of a specific $1-N$-oxidase in Alexandrium that converts GTX II and GTX III to GTX I and GTX IV respectively (Oshima, 1995), further suggest that 1-Noxidation is a post-sulfatation process. A combination of the above information, toxin compositions of different organisms and the suite of derivatives that have been isolated from STX producing organisms, allows us to start assembling a picture of how the multiple STX derivatives could be biochemically interconnected (Fig. 3). New insights on the enzymes responsible for the interconversions will be gained from more detailed labeling studies and analysis of changes in toxin composition over time, as toxin profiles are a reflection of enzyme activities involved in those pathways (Oshima, 1995).

\section{PHYSIOLOGY OF SAXITOXIN PRODUCTION}

Analyzing the variability in toxicity that can occur with different growth conditions or between different isolates of the same species is of fundamental importance to an understanding of saxitoxin biosynthesis. Toxicity can be studied at two different levels: Changes in 'toxin content', i.e., in the overall toxicity of a cell resulting from the integrated potency of all toxins present, or variations in 'toxin composition', i.e., in the number and relative proportions of toxins present in the cell. Moreover, the organisms can be studied in batch culture, therefore showing changes in toxicity as the cells go from lag over exponential to plateau phase, or in continuous or semi-continuous culture, where toxicity can be determined under different evironmental conditions during balanced and adapted growth of the dinoflagellates (Anderson, 1990).

A significant amount of research has dealt with changes in toxicity and hence toxin production rates during the growth cycle of dinoflagellates in batch culture. In general, 
toxin content per cell as well as toxin production rates are highest during early to mid exponential growth of the population. Coinciding with the depletion of a limiting nutrient or an increase in environmental stress that will lead the population into the non-growth stationary phase, toxin content and synthesis rate decrease in parallel to a general decline in cell metabolism. This is the case for limiting inorganic nutrients such as nitrogen or $\mathrm{CO}_{2}$ and environmental factors such as light, salinity and temperature (Proctor et al., 1975; White, 1978; Hall, 1982; Boyer et al., 1987; Ogata et al., 1987; Anderson et al., 1990b; Kim et al., 1993; Flynn et al., 1994; Usup et al., 1994; Flynn et al., 1996; Matsuda et al., 1996). A widely accepted explanation to this phenomenon invokes a reallocation of nitrogen and energy sources in the cell, assuming a possible role of STX as a storage secondary metabolite for nitrogen and a reduced availability of precursors of STX biosynthesis such as arginine and ornithine, which would result in lower toxin content (Boyer et al., 1987; Anderson et al., 1990b). One exception to these dynamics is growth under phosphate-limited conditions. In this case, toxin content and toxin production rates increase significantly as cells enter stationary phase, a time when there is also an increase in the ratio of toxin production to protein or free amino acid synthesis (Boyer et al., 1987; Anderson et al., 1990b; Flynn et al., 1994; Flynn et al., 1996). This decoupling of toxin production from other cellular processes most likely mirrors an inhibitory effect of phosphate deprivation on amino acid, and most importantly, protein metabolism (Flynn et al., 1994). Such a process could induce the cell to allocate some of the nitrogen not incorporated into or catabolized from proteins toward highly nitrogenous compounds such as STX. This would serve as a means of nitrogen storage or detoxification from potentially dangerous levels of ammonia due to non incorporation into aminoacids (Anderson, 1990; Flynn et al., 1996).

In regards to variations in toxin composition over the growth cycle of dinoflagellates, the general observation is that the relative amounts of the different STX derivatives remain 
Fig. 3 Scheme of the information currently available on transformations among STX derivatives in dinoflagellates. Only 11- $\beta$-epimers are represented (Denominations of 11- $\alpha$-epimers are given in round brackets). Alternative names of some compounds are indicated in square brackets. (Broad arrows denote confirmed pathways; dotted arrow represents a putative transformation; the compound enclosed in square brackets has not been isolated from dinoflagellates). 


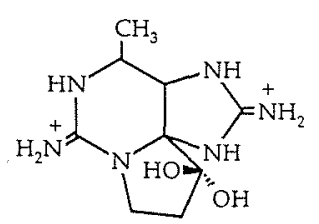

13-deoxy-decarbamoyl-STX

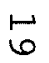

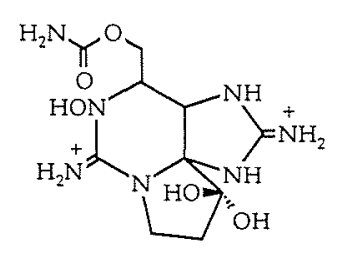

Neosaxitoxin

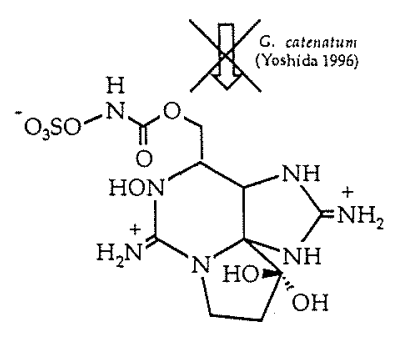

BII [GTX VI]
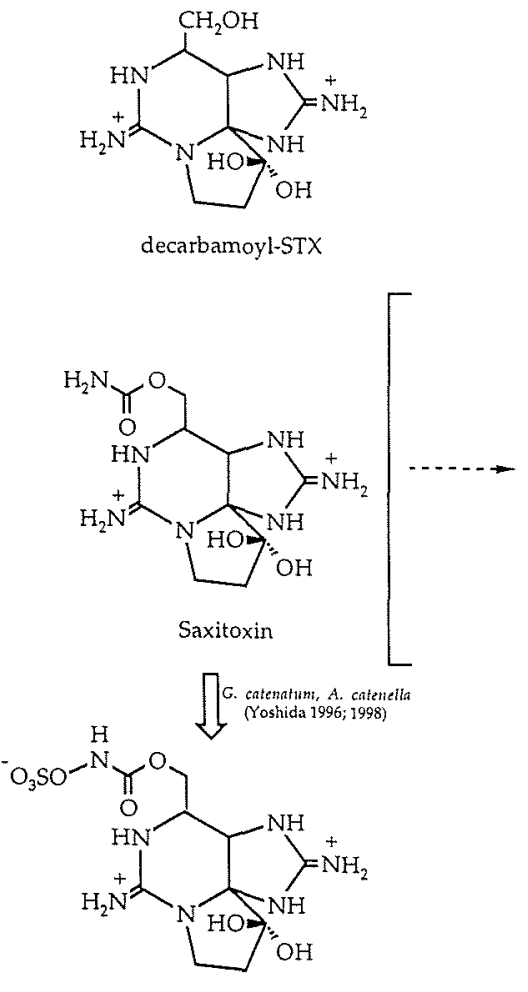

BI [GTX V]

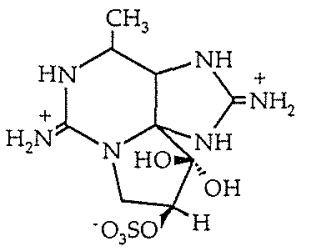

13-deoxy-decarbamoyl-GTX III(II)

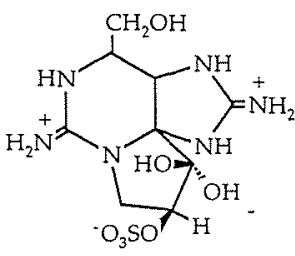

decarbamoyl-GTX III(II)
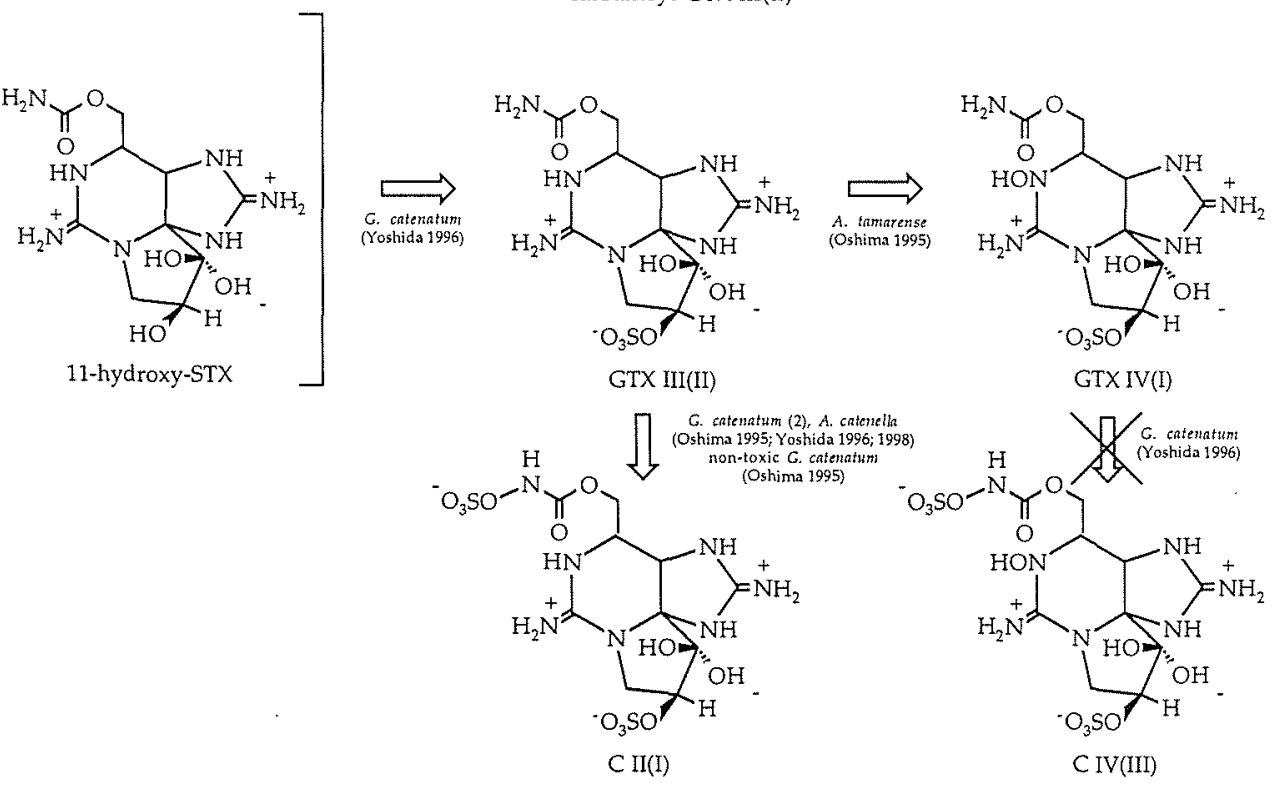
constant (Boyer et al., 1987; Anderson et al., 1990b; Flynn et al., 1994; Sako et al., 1995; Matsuda et al., 1996). Changes have only been observed under extreme growth-limited conditions in late stationary phase, probably due to a general loss of regulatory capacity or a change in the chemical environment of the cell (Boczar et al., 1988), and under progressive nitrogen or phosphorus limitation conditions sustained long enough for the cells to adapt their metabolic machinery to the new demands (Anderson et al., 1990a; MacIntyre et al., 1997).

A fundamental difference when studying toxin production dynamics in continuous or semi continuous cultures is that the cells are analyzed once a state of balanced exponential growth has been reached. Therefore, the influence of factors such as growth rate and residual internal pools of nutrients are minimized. The homeostasis adopted by the cell reflects the interaction between general metabolism and toxin biosynthesis. The effects of nitrogen, phosphate and temperature limitation on STX metabolism have been studied (Anderson et al., 1990b; Matsuda et al., 1996). In the case of nutrient limitation, the growth rates of the organisms are correlated to the availability of the limiting factor in the medium. Nitrogen limitation induces a decrease in toxicity (Anderson et al., 1990a; Matsuda et al., 1996). Phosphate limitation has the opposite effect in semi-continuous culture (Anderson et al., 1990a), which is also observed in plateau phase in batch cultures (Boyer et al., 1987; Anderson, 1990). A direct correlation has also been observed between growth rates and toxin production rates or toxin levels (Anderson et al., 1990b; Matsuda et al., 1996).

In contrast to what has been observed in batch culture and during progression through the growth cycle, toxin composition can change in some dinoflagellates (Alexandrium fundyense and A.tamarense) depending on physico-chemical parameters (Anderson et al., 1990a; MacIntyre et al., 1997), but not vary significantly in other species (A. catenella) under similar conditions (Matsuda et al., 1996). The most plausible explanation for this 
observation is that the shifts in toxin profile in the former examples were a product of long term acclimation of the cells to new conditions of nutrient deprived, yet balanced growth (MacIntyre et al., 1997), while in the latter experiments with A. catenella the nutrient stress in the cells might not have been as limiting due to the shorter duration of the experiments (Matsuda et al., 1996).

The general picture that emerges from these studies is that toxin production varies in accordance to the physico-chemical environment of the cell, but is also dependent on cellular processes such as cell cycle and protein production. Most factors affecting toxin production also influence the general metabolism and growth of the cell, e.g., temperature and nitrogen limitation. On the other hand, conditions such as phosphate limitation clearly do not affect toxin biosynthesis in the same way they modulate other cellular processes, resulting in an uncoupling of these metabolic activities from each other with consequences for the toxicity and physiology of the organism.

\section{GENETICS OF SAXITOXIN}

Analogous to other processes in the cell, toxin biosynthesis is ultimately determined by a series of regulatory events that modulate the activity of the genes encoding the toxin biosynthetic enzymes. The identification of such genes remains a daunting task, as the use of conventional genetic tools such as mutational analysis or transformation with dinoflagellates is constrained by biological and technical factors including lack of information on the number of copies of 'toxin genes', limitations in culturing dinoflagellates on solid media and the high content of DNA per cell that would make it necessary to screen unrealistic numbers of clones in order to detect one mutant. 
Nonetheless, classical genetic analysis to determine the location of the toxin genes and some first attempts to use molecular techniques are underway.

Alexandrium is a heterothallic, haploid organism. Under the appropriate physicochemical conditions vegetative cells will produce gametes. Two gametes of different mating types then fuse to form a zygote which after a suitable period of dormancy undergoes meiosis, resulting in tetrads of vegetative cells that can be recovered individually and established in culture (Pfiester and Anderson, 1987). Genetic analysis of haploid organisms is facilitated by the direct expression of the nuclear genotype in the phenotype and by the presence of tetrads, which permits the quantitative analysis of meiotic products and the determination of recombination frequencies. Heterothallism is instrumental when trying to determine if a genetic trait follows uniparental inheritance, implying mitochondrial or chloroplastidial localization of the genes, or true independent Mendelian segregation, which would suggest nuclear genes. Finally, quantitative tetrad analysis allows the presence or absence of extranuclear or cytoplasmic inheritance factors, such as plasmids or bacteria to be assessed, as these would result in random distributions of a trait in the progeny.

Crosses of toxic and non-toxic strains of Gymnodinium catenatum result in a 1:1 ratio of toxic to non-toxic cells in the F1 generation and a toxin profile in the offspring identical to the parental (P) one (Oshima et al., 1993). The toxic phenotype further segregates independently from mating type in this species. Both these observations, non-random inheritance of toxigenicity and independence from mating type, clearly suggest nuclear localization of the 'toxin genes'. Other studies in which toxic strains of Alexandrium sp. or Gymnodinium sp. were crossed with other toxic representatives of their same species show a 1:1 Mendelian inheritance pattern for toxin profiles that is also independent of mating type (Sako et al., 1992; Ishida et al., 1993; Oshima et al., 1993; Kim et al., 1995; Sako et al., 1995). In some cases, over a $50 \%$ of recombination, relative to the toxin profiles, has been 
observed to occur in the F1 generation in Alexandrium (Ishida et al., 1993). In test crosses between recombinants the phenotype reverts $100 \%$ to the parental $(\mathrm{P})$ type. Moreover, crosses between non-recombinant $\mathrm{F} 1$ individuals also result in a high recombination frequency $(>50 \%)$ and $\mathrm{F} 2$ recombinant phenotypes identical to the $\mathrm{F} 1$ recombinant phenotypes (Ishida et al., 1993). Back-crossing of a recombinant phenotype with one of the parental phenotypes results in a non-recombination cross. This strict recombination pattern suggests a close link among the STX transforming genes/enzymes. Moreover, the identical recombinant phenotypes and their reversal to the original parental phenotypes also imply one recombination site and the transfer of only one specific gene or set of genes that is responsible for the phenotypic variation. Close analysis of the actual compositional changes resulting from recombination are unfortunately too complex to shed any more light on the nature of the transforming enzymes.

In accordance with the mating studies suggesting that no extrachromosomal factors are involved in toxin production, efforts to physically identify plasmids in toxic dinoflagellates and cyanobacteria have also failed (Boczar et al., 1991; Shimizu et al., 1996). The combination of all these observations unequivocally suggests that the genes encoding for the STX biosynthetic and interconverting enzymes in dinoflagellates are localized on nuclear chromosomes.

As we look back, we see that numerous studies have analyzed the chemical structure and activity of STX and its derivatives as well as the physiology of STX production by different dinoflagellates under varying physico-chemical conditions. Initial steps have also been taken to isolate enzymes involved in the interconversions among STX derivatives, but the fundamental question regarding the metabolic role of STX within dinoflagellates remains unanswered. Only a complete understanding of the actual mechanism of STX 
biosynthesis and its regulation will reveal the function and significance of STX production in dinoflagellates. In order to accomplish this, our focus has to be directed toward new approaches to the study of STX biosynthesis in dinoflagellates.

The aim of this thesis was to study STX biosynthesis in the dinoflagellate Alexandrium fundyense by combining high resolution physiological studies in the context of the cell cycle with analysis of genes expressed during toxin production. This approach was intended at identifying genes and hence enzymes putatively involved in STX biosynthesis. In the first chapter the close link between toxin production and the cell cycle in synchronized cultures of $A$. fundyense is decribed. In the second chapter the influence of temperature and phosphate limitation, two factors known to affect STX production, on the linkage between toxin biosynthesis and the different phases of the cell cycle is analyzed. The information gathered from the preceeding chapters is used in chapter three in combination with a novel molecular technique called differential display to identify genes expressed while toxin biosynthesis is active in A. fundyense. 


\section{REFERENCES}

Alam, M., Shimizu, Y., Ikawa, M. and Sasner, J. J., Jr (1978) Reinvestigation of the toxins from the bluegreen alga Aphanizomenon flos-aquae by a high performance chromatographic method. J. Env. Sci. Hlth A13, 493-499.

Anderson, D. M. (1989) Toxic algal blooms and red tides: A global perspective. In Red tides: Biology, Environmental science, and toxicology, ed. Okaichi, Anderson, D. M. and Nemoto, pp. 11-16. Elsevier Science Publishing, New York.

Anderson, D. M. (1990) Toxin variability in Alexandrium species. In Toxic marine phytoplankton, ed. E. Graneli, Sundstrom, B., Edler, L. and Anderson, D. M., pp. 41-51. Elsevier,

Anderson, D. M., Kulis, D. M., Sullivan, J. J. and Hall, S. (1990a) Toxin composition variations in one isolate of the dinoflagellate Alexandrium fundyense. Toxicon 28 , 885-893.

Anderson, D. M., Kulis, D. M., Sullivan, J. J., Hall, S. and Lee, C. (1990b) Dynamics and physiology of saxitoxin production by the dinoflagellates Alexandrium spp. Mar. Biol. 104, 511-524.

Boczar, B. A., Beitler, M. A., Liston, J., Sullivan, J. J. and Cattolico, R. A. (1988) Paralytic shellfish toxins in Protogonyaulax tamarensis and Protogonyaulax catenella in axenic culture. Pl. Physiol. Wash. 88, 1285-1290.

Boczar, B. A., Beitler, M. K., Liston, J., Sullivan, J. J. and Cattolico, R. A. (1991) Characterization of satellite DNA from three marine dinoflagellates (Dinophyceae): Glenodinium sp. and two members of the toxic genus Protogonyaulax. Plant. Physiol. 97, 613-618.

Boyer, G. L., Sullivan, J. J., Andersen, R. J., Harrison, P. J. and Taylor, F. J. R. (1987) Effects of nutrient limitation on toxin production and composition in the marine dinoflagellate Protogonyaulax tamarensis. Mar. Biol. 96, 123-128.

Cembella, A. D., Sullivan, J. J., Boyer, G. L., Taylor, F. J. R. and Andersen, R. J. (1987) Variation in paralytic shellfish toxin composition within the Protogonyaulax tamarensis/catenella species complex: red tide dinoflagellates. Biochem. System. Ecol. 15, 171-186.

Doucette, G. J. and Trick, C. G. (1995) Characterization of bacteria associated with different isolates of Alexandrium tamarense. In Harmful Marine Algal Blooms, ed. P. Lassus, Arzul, G., Erard, E., Gentien, P. and Marcaillou, C., pp. 33-38. Paris.

Estrada, M., Sanchez, F. J. and Fraga, S. (1984) Gymnodinium catenatum (Graham) en las rias gallegas (NO de España). Investigación Pesq. 48, 31-40. 
Fensome, R. A., Taylor, F. J. R., Noris, G., Sarjeant, W. A. S., Wharton, D. I. and Williams, G. L. (1993) A classification of living and fossil dinoflagellates. Vol 7 Micropaleontology special series. American Museum of Natural History, New York.

Flynn, K., Franco, J. M., Fernández, P., Reguera, B., Zapata, M., Wood, G. and Flynn, K. J. (1994) Changes in toxin content, biomass and pigments of the dinoflagellate Alexandrium minutum during nitrogen refeeding and growth into nitrogen or phosphorus stress. Mar. Ecol. Prog. Ser. 111, 99-109.

Flynn, K. J., Flynn, K., John, E. H., Reguera, B., Reyero, M. I. and Franco, J. M. (1996) Changes in toxins, intracellular and dissolved free amino acids of the toxic dinflagellate Gymnodinium catenatum in response to changes in inorganic nutrients and salinity. J. Plankton Res. 18, 2093-2111.

Franca, S., Pinto, L., Alvito, P., Sousa, I., Vasconcelos, V. and Doucette, G. J. (1996) Studies on prokaryotes associated with PSP producing dinoflagellates. In Harmful and Toxic Algal Blooms, ed. T. Yasumoto, Oshima, Y. and Fukuyo, Y., pp. 347-350. UNESCO, Paris.

Gallacher, S., Flynn, K. J., Leftley, J., Lewis, J., Munro, P. D. and Birbeck, T. H. (1996) Bacterial production of sodium channel blocking toxins. In Harmful and Toxic Algal Blooms, ed. T. Yasumoto, Oshima, Y. and Fukuyo, Y., pp. 355-358.

UNESCO, Paris.

Geraci, J. R., Anderson, D. M., Timperi, R. J., St. Aubin, D. J., Early, G. A., Prescott, J. H. and Mayo, C. A. (1989) Humpback whales (Megaptera, novaeangliae)fatally poisoned by dinoflagellate toxin. Can. J. Fish. Aquat. Sci. 46, 1895-1898.

Hall, S. (1982) Toxins and toxicity of Protogonyaulax from the northeast Pacific, Ph.D., Univ. of Alaska.

Hall, S., Strichartz, G., Moczydlowski, E., Ravindran, A. and Reichardt, P. B. (1990) The saxitoxins: sources, chemistry and pharmacology. In Marine Toxins: Origin, Structure and Molecular Pharmacology, ed. S. Hall and Strichartz, G., pp. 29-65. American Chemical Society, Washington.

Harada, T., Oshima, Y., Kamiya, H. and Yasumoto, T. (1982) Confirmation of paralytic shellfish toxins in the dinoflagellate Pyrodinium bahamense var. compressa and bivalves from Palau. Nippon Suisan Gakkaishi 48, 821-825.

Humpage, A. R., Rositano, J., Bretag, A. H., Brown, R., Baker, P. D., Nicholson, B. C. and Steffensen, D. A. (1994) Paralytic shellfish poisons from Australian cyanobacterial blooms. Aust. J. Mar. Freshwat. Res. 45, 761-771.

Ishida, Y., Kim, C.-H., Sako, Y., Hirooka, N. and Uchida, A. (1993) PSP toxin production is chromosome dependent in Alexandrium spp. In Toxic phytoplankton blooms in the sea, ed. T. J. Smayda and Shimizu, Y., pp. 881-887. Elsevier, Amsterdam. 
Kim, C.-H., Sako, Y. and Ishida, Y. (1993) Variation of toxin production and composition in axenic cultures of Alexandrium catenell and A. tamarense. Nippon Suisan Gakkaishi 59, 633-639.

Kim, C. H., Sako, Y. and Ishida, Y. (1995) Inheritance of PSP toxin composition in the toxic dinoflagellate Alexandrium spp. Korean J. Phycol. 10, 59-67.

Kodama (1990) Possible links between bacteria and toxin production in algal blooms. In Toxic Marine Phytoplankton, ed. E. Granéli, Sundström, B., Edler, L. and Anderson, D. M., pp. 52-61. Elsevier, New York.

Kodama, M., Ogata, T. and Sato, S. (1988) Bacterial production of saxitoxin. Agric. Biol. Chem. 52, 1075-1077.

Kodama, M., Ogata, T., Sato, S. and Sakamoto, S. (1990) Possible association of marine bacteria with paralytic shellfish toxicity of bivalves. Mar. Ecol. Prog. Ser. 61, 203206.

Leete, E. (1969) Alkaloid biosynthesis. Adv. Enzymol. 32, 373-422.

Levasseur, M., Monfort, P., Doucette, G. J. and Michaud, S. (1996) Preliminary study of bacteria as PSP producers in the gulf of St. Lawrence, Canada. In Harmful and Toxic Algal Blooms, ed. T. Yasumoto, Oshima, Y. and Fukuyo, Y., pp. 363-366. UNESCO, Paris.

Lipkind, G. M. and Fozzard, H. A. (1994) A structural model of the tetrodotoxin and saxitoxin binding site of the $\mathrm{Na}^{+}$channel. Biophys. J. 66, 1-13.

MacIntyre, J. G., Cullen, J. J. and Cembella, A. D. (1997) Vertical migration, nutrition and toxicity in the dinoflagellate Alexandrium tamarense. Mar. Ecol. Prog. Ser. 148, 201-216.

Maclean, J. L. (1973) Red tide and paralytic shellfish poisoning in Papua New Guinea. Papua New Guinea Agric. J. 24, 131-138.

Matsuda, A., Nishijima, T. and Fukai, K. (1996) Effects of nitrogen deficiency on the PSP production by Alexandrium catenella under axenic cultures. In Harmful and Toxic Algal Blooms, ed. T. Yasumoto, Oshima, Y. and Fukuyo, Y., pp. 305-308. UNESCO, Paris.

Meyer, K. F., Sommer, H. and Schoenholz, P. (1928) Mussel poisoning. J. Prevent. Med. 2, 365-394.

Montoya, N. G., Akselman, R., Franco, J. and Carreto, J. I. (1996) Paralytic shellfish toxins and mackerel (Scomber japonicus) mortality in the Argentine sea. In Harmful and Toxic Algal Blooms, ed. T. Yasumoto, Oshima, Y. and Fukuyo, Y., pp. 417-420. UNESCO, Paris.

Narahashi, T. (1988) Cellular mechanisms of action of paralytic shellfish poisons Seventh international IUPAC symposium on mycotoxins and phycotoxins 425-436. 
Ogata, T., Kodama, M. and Ishimaru, T. (1987) Toxin production in the dinoflagellate Protogonyaulax tamarensis. Toxicon 25, 923-928.

Ogata, T., Kodama, M., Komaru, K., Sakamoto, S., Sato, S. and Simidu, S. (1990) Production of paralytic shellfish toxins by bacteria isolated from toxic dinoflagellates. In Toxic Marine Phytoplankton, ed. E. Granéli, Sundström, B., Edler, L. and Anderson, D. M., pp. 311-315. Elsevier, New York.

Ogata, T., Koike, K., Nomura, S. and Kodama, M. (1996) Utilization of organic substances for growth and toxin production by Alexandrium tamarense. In Harmful and Toxic Algal Blooms, ed. T. Yasumoto, Oshima, Y. and Fukuyo, Y., pp. 343-346. UNESCO, Paris.

Oshima, Y. (1995) Chemical and enzymatic transformation of paralytic shellfish toxins in marine organisms. In Harmful Marine Algal Blooms, ed. P. Lassus, Arzul, G. and Erard, E., pp. 475-480. Lavoisier, Paris.

Oshima, Y., Blackburn, S. I. and Hallegraeff, G. M. (1993) Comparative study on paralytic shellfish toxin profile of the dinoflagellate Gymnodinium catenatum from thre different countries. Mar. Biol. 116, 471-476.

Oshima, Y., Hasegawa, M., Yasumoto, T., Hallegraeff, G. and Blackburn, S. (1987) The dinoflagellate Gymnodinium catenatum as the source of paralytic shellfish toxins in Tasmanian shellfish. Toxicon 25, 1105-1111.

Oshima, Y., Itakura, H., Lee, K.-C., Yasumoto, T., Blackburn, S. and Hallegraeff, G. (1993) Toxin production by the dinoflagellate Gymnodinium catenatum. In Toxic Phytoplankton Blooms in the Sea, ed. T. J. Smayda and Shimizu, Y., pp. 907-912. Elsevier, Amsterdam.

Pfiester, L. A. and Anderson, D. M. (1987) Dinoflagellate reproduction. In The Biology of Dinoflagellates, ed. F. J. R. Taylor, pp. 611-648. Blackwell Scientific Publications, Oxford.

Proctor, N. H., Chan, S. L. and Trevor, A. J. (1975) Production of saxitoxin by cultures of Gonyaulax catenella. Toxicon 13, 1-9.

Rausch de Traubenberg, C. and Lassus, P. (1991) Dinoflagellate toxicity: Are marine bacteria envolved? Evidence from the literature. Mar. Microb. Food Webs 5, 205-226.

Sakamoto, S., Ogata, T., Sato, S., Kodama, M. and Takeuchi, T. (1992) Causative organism of paralytic shellfish toxins other than toxic dinoflagellates. Mar. Ecol. Prog. Ser. 89, 229-235.

Sako, Y., Kim, C. and Ishida, Y. (1992) Mendelian inheritance of paralytic shellfish poisoning toxin in the marine dinoflagellate Alexandrium catenella. Biosc. Biotech. Biochem. 56, 692-694.

Sako, Y., Naya, N., Yoshida, T., Kim, C.-H., Uchida, A. and Ishida, Y. (1995) Studies on stability and heredety of PSP toxin composition in the toxic dinoflagellate 
Alexandrium. In Harmful Marine Algal Blooms, ed. P. Lassus, Arzul, G., Erard, E., Gentien, P. and Marcaillou, C., pp. 345-350. Lavoisier, Paris.

Schantz, E. J., Ghazarossian, V. E., Schnoes, H. K., Strong, F. M., Springer, J. P., Pezzanite, J. O. and Clardy, J. (1975) Paralytic poisons from marine dinoflagellates. In The first international conference on toxic dinoflagellate blooms, ed. V. R. LoCicero, pp. 267-274. The Massachusetts Science and Technology Foundation, Boston.

Shimizu, Y. (1993) Microalgal metabolites. Chem. Rev. 93, 1685-1698.

Shimizu, Y., Giorgio, C., Koerting-Walker, C. and Ogaa, T. (1996) Nonconformity of bacterial production of paralytic shellfish poisons: Neosaxitoxin production by a bacterium strain from Alexandrium tamarense Ipswitch strain and its significance. In Harmful and Toxic Algal Blooms, ed. T. Yasumoto, Oshima, Y. and Fukuyo, Y., pp. 359-362. UNESCO, Paris.

Shimizu, Y., Norte, M., Hori, A., Genenah, A. and Kobayashi, M. (1984) Biosynthesis of saxitoxin analogues: The unexpected pathway. J. Amer. Chem. Soc. 106, 64336434.

Shumway, S. E. (1990) A review of the effects of algal blooms on shellfish and aquaculture. J. World Aquacult. Soc. 21, 65-104.

Silva, E. S. (1982) Relationship between dinoflagellates and intracellular bacteria. In Marine Algae in Pharmaceutical Science, ed. H. A. Hoppe and Levring, T., pp. 269288. Walter de Gruyter \& Co., New York.

Singh, H. T., Oshima, Y. and Yasumoto, T. (1982) Growth and toxicity of Protogonyaulax tamarensis in axenic culture. Nippon Suisan Gakkaishi 48, 13411343.

Sommer, H., Whedon, W. F., Kofoid, C. A. and Stohler, R. (1937) Relation of paralytic shellfish poison to certain plankton organisms of the genus Gonyaulax. Am. Med. Assoc. Arch. Pathol. 24, 537-559.

Steidinger, K. A. and Moestrup, Ø. (1990) The taxonomy of Gonyaulax, Pyrodinium, Alexandrium, Gessnerium, Protogonyaulax and Goniodoma. In Toxic Marine Phytoplankton, ed. E. Granéli, Sundström, B., Edler, L. and Anderson, D. M., pp. 522-523. Elsevier, New York.

Taylor, F. J. R. (1987) General group characteristics; special features of interest; short history of dinoflagellate study. In The Biology of Dinoflagellates, ed. F. J. R. Taylor, pp. 1-23. Blackwell, Oxford.

Usup, G., Kulis, D. M. and Anderson, D. M. (1994) Growth and toxin production of the toxic dinoflagellate Pyrodinium bahamense var. compressum in laboratory cultures. Nat. Tox. 2, 254-262.

White, A. W (1978) Salinity effects on growth and toxin content of Gonyaulax excavata, a marine dinoflagellate causing paralytic shellfish poisoning. J. Phycol. 14, 475-479. 
White, A. W., Fukuhara, O. and Anraku, M. (1989) Mortality of fish larvae from eating toxic dinoflagellates or zooplankton containing dinoflagellate toxins. In Red Tides: Biology, Environmental Science and Toxicology, ed. T. Okaichi, Anderson, D. M. and Nemoto, T., pp. 395-398. Elsevier, New York.

Yoshida, T., Sako, Y., Uchida, A., Ishida, Y., Arakawa, O. and Noguchi, T. (1996) Purification and properties of paralytic shellfish poisoning toxins sulfotransferase from toxic dinoflagellate Gymnodinium catenatum. In Harmful and Toxic Algal Blooms, ed. T. Yasumoto, Oshima, Y. and Fukuyo, Y., pp. 499-502. UNESCO, Paris. 


\section{CHAPTER I}

\section{Toxin variability during the cell cycle of the dinoflagellate Alexandrium fundyense *}

The American Society of Limnology and Oceanography, Inc., hereby grants Gaspar Taroncher Oldenburg a non-exclusive, world-wide, royalty-free license to copy and distribute the article entitled "Toxin variability during the cell cycle of the dinoflagellate Alexandrium fundyense" by G. Taroncher Oldenburg, D.M. Kulis, and D.M. Anderson as published in Limnology and Oceanography, 42 (5, part 2): 1178-1188 solely as a chapter in the following work: Taroncher Oldenburg, Gaspar, "Cell Cycle Dynamics and the Physiology of Saxitoxin Biosynthesis in Alexandrium fundyense (Dinophyceae)" (Ph.D. Thesis, MIT/WHOI Joint Program in Oceanography/Applied Ocean Science and Engineering, 1998). Any right to copy and/or distribute the article when not incorporated in this thesis shall require further permission from the American Society of Limnology and Oceanography, Inc.

* Published in Limnol. Oceanogr. 42 (5-2): pp. 1178-1188, 1997.

G. Taroncher-Oldenburg, D. M. Kulis and D. M. Anderson 


\section{ABSTRACT}

Cultures of the toxic dinoflagellate Alexandrium fundyense Balech were subjected to conditions which induced two synchronized divisions over a period of 48 hours. Before, during and after this interval, toxin content, toxin composition, and several other physiological parameters were monitored every two hours for 94 hours. Toxin production was discontinuous, was induced by light and always occured during a defined time frame within the $G_{1}$ phase of the cell cycle. Specific toxin production rates were positive for a period of approximately eight to ten hours in early $G_{1}$ and dropped to zero for the remainder of the interphase and mitosis. Analysis of toxin composition showed that cellular concentrations of all the saxitoxin derivatives followed a similar pattern of increase, stabilization and decrease throughout one generation time. A putative sequence of interconversions between the derivatives could be established, with $\mathrm{C} 2$ as the first compound to appear. Division of a subset of the population during the first 24 hours of the experiment and the ensuing total synchrony of the culture suggest the existence of two transition points in the cell cycle of this dinoflagellate. The first transition point, at the beginning of $G_{1}$, is light-dependent and holds the cells in a $G_{0}$-like period. The second block point at the end of $G_{1}$ is size-dependent and arrests the cells in $G_{1}$. We propose a model of the cell cycle of $A$. fundyense in which progression through the cell cycle can be arrested at two different transition points located in $\mathrm{G}_{1}$ and toxin production is induced by light during $\mathrm{G}_{1}$. The restriction of toxin production to a relatively short segment of the cell

cycle provides a tool for comparing cells that are and are not synthesizing toxin. This has important implications and applications in the study of genetic and biochemical regulation of toxin production in Alexandrium. 


\section{INTRODUCTION}

Dinoflagellate species in the genus Alexandrium are responsible for paralytic shellfish poisoning (PSP) along the northeastern coast of the United States and Canada (Maranda et al. 1985; Cembella et al. 1987; Anderson 1989), as well as other temperate littoral waters throughout the world (Hallegraeff 1993). PSP is caused by saxitoxin (STX), a potent neurotoxin produced by some Alexandrium species, and over twenty known STX derivatives which differ in structure and toxicity (Shimizu 1993). An important characteristic of the STX-producing dinoflagellates is that the toxicity of a single isolate can vary dramatically under different growth conditions. This variability is largely due to changes in toxin content (the integrated potency or total molar content of toxin per cell) during various stages of growth (Hall 1982; Boyer et al. 1987; Anderson et al. 1990b), but it can also reflect changes in toxin composition (the relative concentrations of the different STX derivatives) (Boczar et al. 1988; Anderson et al. 1990a).

Most studies to date have examined the toxin content of dinoflagellates on time scales of days to weeks using batch cultures. These studies have shown that toxin content varies with nutrient limitation (Hall 1982; Boyer et al. 1987; Anderson 1990) and with changes in salinity (White 1978), temperature (Hall 1982; Ogata et al. 1987; Anderson et al. 1990b) or light intensity (Ogata et al. 1987). A typical pattern, observed for all these conditions except phosphorous limitation, is that toxin content is highest in early exponential growth and decreases as the cells enter stationary phase (Boyer et al. 1987; Boczar et al. 1988; Anderson et al. 1990b). Furthermore, specific toxin production rates were observed to be directly proportional to specific growth rates, suggesting that toxin synthesis might be linked to cell cycle events (Anderson et al. 1990b).

Dinoflagellates have several characteristics, such as permanently condensed chromosomes and the absence of histones, that place them as a unique group among the 
eukaryotes (Rizzo 1987; Rizzo 1991). However, recent evidence also suggests that their cell cycle is controlled by universal eukaryotic regulatory mechanisms such as $c d c 2$-like protein kinases (Rodriguez et al. 1994; Van Dolah et al. 1995). The typical eukaryotic cell cycle initiates with the mitotic division of the cells ( $M$ phase) followed by interphase, consisting of three segments, $G_{1}, S$ and $G_{2}$. During the first segment, $G_{1}$, the cells are metabolically very active. The $S$ phase, when DNA synthesis occurs, follows $G_{1}$ and extends until chromosome replication occurs and the DNA content of the cell has doubled. The cell then enters $G_{2}$, which lasts until mitosis occurs again. When conditions are unfavorable, some cells can withdraw from the regular cell division cycle and enter a reversible cell cycle arrest phase $\left(\mathrm{G}_{0}\right)$ during $\mathrm{G}_{1}$ (Prescott 1976). The time taken to proceed through one complete cell division is the generation time of the cell.

In order to determine the onset of a metabolic process within the cell cycle, as was our object, all the cells in a culture must proceed through the different stages and divide at the same time. Dinoflagellate division can be phased by the photoperiod and occur during a clearly defined interval such as the dark-to-light transition (Chisholm 1981). However, since dinoflagellate growth rates in culture are typically less than one division per day, only a portion of the population will divide over one photoperiod. Cells that are not ready to divide must proceed from their respective positions in the cell cycle through DNA synthesis and, eventually, mitosis during the next or subsequent light period. Measurements on phased cultures thus represent an average of the physiological status of cells in several different metabolic states at the time of sampling (Chisholm 1981). Synchronized cultures are therefore required, yet this is difficult to accomplish with dinoflagellates. Several methods have been used in the past to synchronize dinoflagellates. Gonyaulax polyedra was synchronized using a sieving technique that separated cell cycle stages on the basis of cell size (Homma and Hastings 1988). This approach, however, requires excessively large volumes of culture in order to obtain sufficient biomass for the measurements of interest to 
our study. Amphidinium carterae was synchronized by manipulating the length of the light-dark cycle (Galleron and Durrand 1976), a method that did not work with Alexandrium fundyense cultures in our hands (unpublished data).

Alternatively, a block/release approach can be used to synchronize cells. This method is based on the hypothesis that cells arrested by an external factor at a specific point during their cell cycle will proceed through the rest of the cell cycle stages as a homogeneous population after being released from the constraint (Pardee et al. 1978). Such block or "transition" points have been identified during late $\mathrm{G}_{1}$ in mammalian cells (Pardee et al. 1978) and yeast (Johnston et al. 1980). Our efforts to locate such points in dinoflagellate cultures using metabolic inhibitors have not been successful, possibly because the cell wall of dinoflagellates is impermeable to many organic molecules or because the autotrophic nature of the organisms does not facilitate uptake of the inhibitors (unpublished data).

One factor that can arrest cells at a particular point of their cell cycle is light. Light is of primary importance for activating physiological processes as well as determining the timing of cell cycle events in phytoplankton (Chisholm 1981; Vaulot 1985). In phytoplankton, light-dependent block points can be passed by a cell only after it has been exposed to sufficient light. Such transition points have been documented in Chlamydomonas (Spudich and Sager 1980) Amphidinium carterii (Olson and Chisholm 1986) and Hymenomonas carterii and Thalassiosira weisflogii (Vaulot et al. 1986). If the cells are deprived of the minimal light requirement and there is only one light-dependent transition point, and if the length of dark arrest is equal to or greater than the entire cell cycle (i.e. one generation time), all cells should be blocked at the same point. Once the normal light-dark cycle is restored, a synchronized population is obtained.

In this study, we employed a block/release approach, using prolonged darkness to arrest A. fundyense in a light-dependent section of the cell cycle. Cells were released to a normal 14:10 hr light:dark cycle and closely spaced measurements made to determine the 
small-scale dynamics of toxin production. The parameters measured included toxin concentration, toxin composition, DNA content, cell size and total protein.

\section{MATERIALS AND METHODS}

The Organism. The dinoflagellate Alexandrium fundyense (strain GtCA29) was used throughout this study. This clonal culture was established in January 1985 from a cyst isolated from Gulf of Maine sediments, 20 miles east of Portsmouth, New Hampshire (USA). Prior to the experiments, cultures were maintained at $15^{\circ} \mathrm{C}$ in $\mathrm{f} / 2$ medium (Guillard and Ryther 1962) modified by addition of $\mathrm{H}_{2} \mathrm{SeO}_{3}\left(10^{-8} \mathrm{M}\right)$ and by reducing the

concentration of $\mathrm{CuSO}_{4}$ to $10^{-8} \mathrm{M}$. Vineyard Sound seawater $(0.2 \mu \mathrm{m}$ filtered, $31 \%$ salinity) was used as the medium base. Throughout the experiment, irradiance of ca. 250 $\mu \mathrm{Em}^{-2} \mathrm{~s}^{-1}$ was provided by cool white fluorescent bulbs on a $14: 10 \mathrm{~h}$ light:dark cycle.

Synchronization Experiment. Three 20L borosilicate glass carboys containing $17 \mathrm{~L}$ of sterile filtered $f / 2$ medium were inoculated with acclimated exponential phase cells to an initial cell density of ca. 200 cells ml $^{-1}$. The cultures were incubated at $20^{\circ} \mathrm{C}$ and aerated by gentle bubbling with activated-charcoal-filtered air. After completion of the light cycle on the third day after inoculation (ca. 400 cells mll $^{-1}$ ), the incubator lights were turned off for a period of 82 hours. One hour before the normal 14:10 LD cycle was restored $\left(t_{0}\right.$ of the experiment), samples for toxin, DNA, cell concentration, and protein were taken from each of the carboys. Samples were collected from all three carboys at hrs 2, 4, 12 and 18, and every two hours from hrs 22 through 94 . The samples were taken from each carboy by blocking the aeration exhaust port of the carboy, thereby pressurizing the vessels and forcing a sample of the culture through a sample tube into the sampling containers. The 
cells were not mixed manually or disturbed by any other physical means. During the dark period and in order to ensure that the cultures were not exposed to light, sampling was performed under a $6 \mathrm{~W}$, incandescent red light, and special precautions were taken to minimize exposure to stray light.

Toxin Analysis. Between 2.5 and $5 \times 10^{5}$ cells were collected from the sub-samples by centrifugation $\left(3,000 \mathrm{xg}, 23^{\circ} \mathrm{C}\right)$. The resulting pellet was rinsed into a centrifuge tube and resuspended in $0.5 \mathrm{M}$ acetic acid for extraction by sonification. The extracts were stored at $-20^{\circ} \mathrm{C}$ prior to analysis. The extracts were analyzed by HPLC (Oshima et al. 1989) incorporating the modifications previously described by Anderson et al. (1994).

Soluble Protein. At least 50,000 cells were collected by centrifugation $\left(3000 \mathrm{x} \mathrm{g}, 23^{\circ} \mathrm{C}\right)$ for protein quantification. After aspiration of the supernatant, the pellet was stored frozen at $-20^{\circ} \mathrm{C}$. For analysis, $1 \mathrm{ml}$ of $0.1 \mathrm{~N} \mathrm{NaOH}$ was added to the pellet and the suspension sonified for 15 seconds to disrupt the cells. Samples were then digested for $20 \mathrm{~min}$ at $80^{\circ} \mathrm{C}$, centrifuged, and the supernatant removed and neutralized with 0.1 volumes of $1.0 \mathrm{~N}$ $\mathrm{HCl}$ (Binder and Anderson 1990). A $50 \mu 1$ fraction of the neutralized solution was mixed with $1 \mathrm{ml}$ of bicinchoninic acid (BCA) working solution (Pierce, Rockford IL), and the absorbance of duplicate samples determined at $562 \mathrm{~nm}$.

Flow Cytometric Analysis. A $15 \mathrm{ml}$ aliquot of culture was preserved with 5\% formalin $(\mathrm{v} / \mathrm{v})$ and stored at $4^{\circ} \mathrm{C}$. The cells were centrifuged $\left(1700 \times \mathrm{g}, 23^{\circ} \mathrm{C}, 3 \mathrm{mins}\right)$ and the pellet resuspended in $10 \mathrm{ml}$ of ice cold methanol and stored at $4^{\circ} \mathrm{C}$ to extract chlorophyll. The samples were then further concentrated by centrifugation. A subsample of the methanolpreserved material was transferred into a $1.5 \mathrm{ml}$ microcentrifuge tube and pelleted at 2000 rpm. The supernatant was removed and the cells washed with $1 \mathrm{ml}$ PBS (40mM 
$\mathrm{Na}_{2} \mathrm{HPO}_{4}, 22 \mathrm{mM} \mathrm{KH}_{2} \mathrm{PO}_{4}, 85 \mathrm{mM} \mathrm{NaCl}$ ). After centrifugation, the pellet was resuspended in $0.5 \mathrm{ml}$ propidium iodide (PI) staining solution $\left(4 \mu \mathrm{g} \mathrm{ml}^{-1} \mathrm{PI}, 1250\right.$ units RNaseA ml-1) and allowed to react in the dark for at least two hours prior to analysis on an Epics V flow cytometer (Coulter Electronics, Hialeah, FL) (Olson et al. 1986). The results were reduced by running an inside-out and an outside-in model with trapezoidal $\mathrm{S}$ phase fitting on ModFit 5.11 (VERITY Software House, Inc., Topsham, ME).

Cell Size. Cell diameter was determined by analyzing unfixed cells ( $3 \mathrm{ml}$ of the culture)

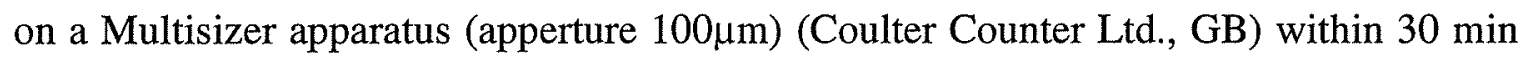
after sampling. Mean sizes were calculated from the Gaussian distributions obtained.

Cell Concentrations. Cell concentrations were determined by counting Utermöhlspreserved samples (Utermöhl 1958). At least 400 cells per sample were counted in a Sedgwick Rafter counting chamber. Cell densities represent the mean of the averaged triplicate counts for each carboy.

Data fitting. Simple, segmented and smoothed linear models were fitted to the cell growth and toxin concentration data. The fitting program uses the Marquardt-Levenberg algorithm to minimize the sum of the squares of the differences between the equation values and the data (SigmaPlot, Jandel Corp.). This is an iterative process that lasts until the model and the data converge. Convergence is achieved when the absolute value of the difference between the square root of the sum of squares of the residuals is less than 0.0001 .

The fitting was done using the equation: 


$$
f_{\mathrm{n}}(t)=\mathrm{k} t+\mathrm{N}_{\mathrm{n}}
$$

where $f(t)$ is a linear function of time, $\mathrm{k}$ is the growth rate (or toxin production rate; units: division hour ${ }^{-1}$ and pmole $\mathrm{ml}^{-1}$ hour ${ }^{-1}$ respectively) and $\mathrm{N}_{\mathrm{n}}$ is the cell concentration (or toxin concentration; units: cells $\mathrm{ml}^{-1}$ and pmoles $\mathrm{ml}^{-1}$ respectively) at the end of compartment $\mathrm{n}-1$. If $\mathrm{X}$ is a parameter for cell concentration (or toxin concentration), $\mathrm{n}$ is the number of the curve segment, and $\mathrm{T}$ is a parameter for time at the endpoints of the different segments, the rate $k$ between $T_{n}$ and $T_{n-1}$ will be given by

$$
k=\frac{X_{n}-X_{n-1}}{T_{n}-T_{n-1}}
$$

Since $f\left(T_{n}\right)=X_{n}, N_{n}$ can be defined as

$$
N_{n}=\frac{X_{n-1} T_{n}-X_{n} T_{n-1}}{T_{n}-T_{n-1}}
$$

Incorporating (2) and (3) into (1) yields a function $f_{\mathrm{n}}(t)$

$$
f_{n}(t)=\frac{X_{n}\left(T_{n}-t\right)+X_{n+1}\left(t-T_{n-1}\right)}{T_{n}-T_{n-1}}
$$

where $f(t)$ is the linear function of time that describes the changes in cell number (or toxin concentration) in each of the segments on Figs. 1A and 1B. Initially, the different values for $\mathrm{T}$ were arbitrarilly specified at the light-dark and dark-light transitions. After several iterations of the model, the time points $\mathrm{T}$ defining the beginning and ending of each 
segment were determined from the best least-square fit to the entire data set. The results were then plotted as a segmented curve together with the actual data.

Abbreviations used throughout this text are: STX = saxitoxin; NEO = neosaxitoxin; GTX $1,2,3,4,5=$ gonyautoxins I, II, III, IV and V; C2 = toxin $C 2 ; \mathrm{G}_{0}, \mathrm{G}_{1}$ and $\mathrm{G}_{2}=$ Gap 0, Gap 1 and Gap 2 phases of the cell cycle; $\mathrm{S}=$ synthesis phase; $\mathrm{M}=$ mitosis.

\section{RESULTS}

All results represent the mean values obtained by averaging data from three independent cultures grown in parallel and started with the same acclimated inoculum.

Synchrony and cell growth. When the dark-arrested cultures were returned to a 10:14 hr light-dark cycle, cell numbers remained constant for 18 hours, with an average concentration $( \pm \mathrm{SD})$ of $723( \pm 61)$ cells $\mathrm{ml}^{-1}$ (Fig. 1A). By hr 26 a new stable population size of 1012 ( \pm 51$)$ cells ml-1 was observed, a $40 \%$ increase from initial levels. This was followed $16 \mathrm{hrs}$ later by a major surge in division, with concentrations doubling to 1999 ( \pm 135) cells $\mathrm{ml}^{-1}$ over an $8 \mathrm{hr}$ interval. This cell density was sustained until hr 66 when a new synchronized division event began that brought the population to 3465 ( \pm 142 ) cells $\mathrm{ml}^{-1}$, a 1.8 fold increase. Cell proliferation always started 3 to 6 hours into the dark phase and lasted for approximately 9 hours.

Linear regressions were calculated for each of the intervals described above. Only the sections delimited by hours 18-26, 42-50 and 66-74 had slopes that were significantly different from zero $(\mathrm{p}<0.001)$. The horizontal, 'non-growth' segments had slopes which were not statistically different from zero ( $p>0.93$, C.I. 97\%). These stepwise linear 
increases in cell concentrations were modeled by fitting a simple, segmented and smoothed linear model to the data (see materials and methods). The fitted curve matched the data extremely well, as shown in Fig. 1A.

Cell Size Distributions. Cell diameter was determined for hrs 0 through 56, and three distinct size classes could be distinguished (Fig. 2). At the end of the dark arrest period, hr 0 , the cells had an equivalent spherical diameter $( \pm$ SD) of $23 \mu \mathrm{m}( \pm 1.2)$. This peak corresponds to the size of cells in $\mathrm{G}_{0}$ (Fig. 4). During the first 24 hours these cells increased in size to $29 \mu \mathrm{m}( \pm 1.4)$, coinciding with a peak in $G_{1}$. Over the next 8 hours their diameter remained constant, starting to increase again at hr 34 and reaching a maximum of $33 \mu \mathrm{m}( \pm 1.6)$, at hour 44 , corresponding to the peak of the $G_{2}+M$ cell cycle stage. Subsequently, the cells rapidly decreased in size to $29 \mu \mathrm{m}( \pm 1.3)$.

Protein Content. Protein content per cell was $400 \mathrm{pg}( \pm 65)$ in the dark arrested cells, but increased once the light was restored, exhibiting a typical bi-modal pattern through time that peaked at the end of the light periods (hrs 15, 39, 63 and 87), and reached minima at the end of the dark periods (hrs 25, 49 and 73) (Fig. 3). The minimum was constant at $523 \mathrm{pg}( \pm 58)$. The first maximum, at hr 15 , was at only $608 \mathrm{pg}( \pm 79)$. All other maxima were at $1106 \mathrm{pg}( \pm 126)$.

Cell Cycle Stages. Two cohorts of cells were apparent in the early stages of the experiment (Fig. 4). The first, comprising approximately $30 \%$ of the total population, appeared 11 hours into the first light period, evidenced as an increase in the percentage of cells in $S$ and a concurrent decrease in $G_{1}$ cells. Shortly thereafter, a small peak in $G_{2}+M$ occured, after which $96 \%$ of the population was in $\mathrm{G}_{1}$ phase at $\mathrm{hr} 22$. This corresponded to a $30 \%$ increase in total cell concentration at that time. The second cohort of cells (the 
Fig.1 Cell division pattern, changes in toxin concentration of the population and specific toxin production rates, $\mu_{\text {Tox }}$, in Alexandrium fundyense Balech (GtCA29) as a function of time and during synchronous growth on a light:dark cycle of 14:10 hours (dark periods indicated by shaded areas). (A) Cell densities and (B) total toxin concentration in the culture measured at 2-hour intervals (Error bars denote $\pm \mathrm{SD}$ ). Data were fitted to simple segmented linear models (continuous line; see text). (C) Specific toxin production rates, $\mu_{\text {Tox }}$ $\left(\mathrm{h}^{-1}\right)$, were obtained from the fitted curve in (B) (see text). 

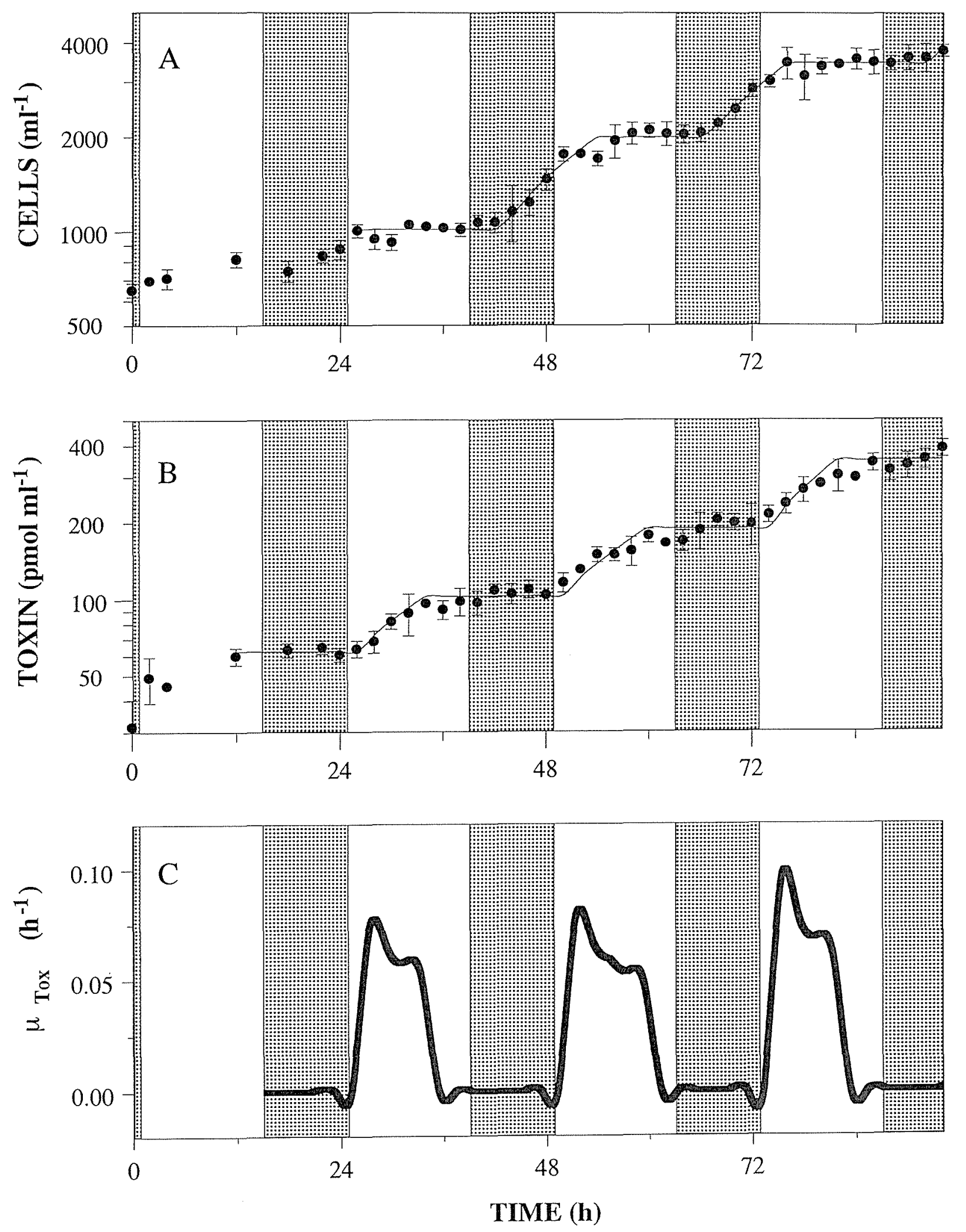
Fig. 2 Variation in the cell size distribution of Alexandrium fundyense Balech (GtCA29) over the first 48 hours of the synchronization experiment (height of areas is equivalent to number of cells). Area with vertical lines corresponds to cells in $G_{0}(23 \pm 1.2 \mu \mathrm{m})$, black areas to $G_{1}(29 \pm 1.4 \mu \mathrm{m})$, and the horizontally lined area to $\mathrm{G}_{2}(33 \pm 1.6 \mu \mathrm{m})$. 


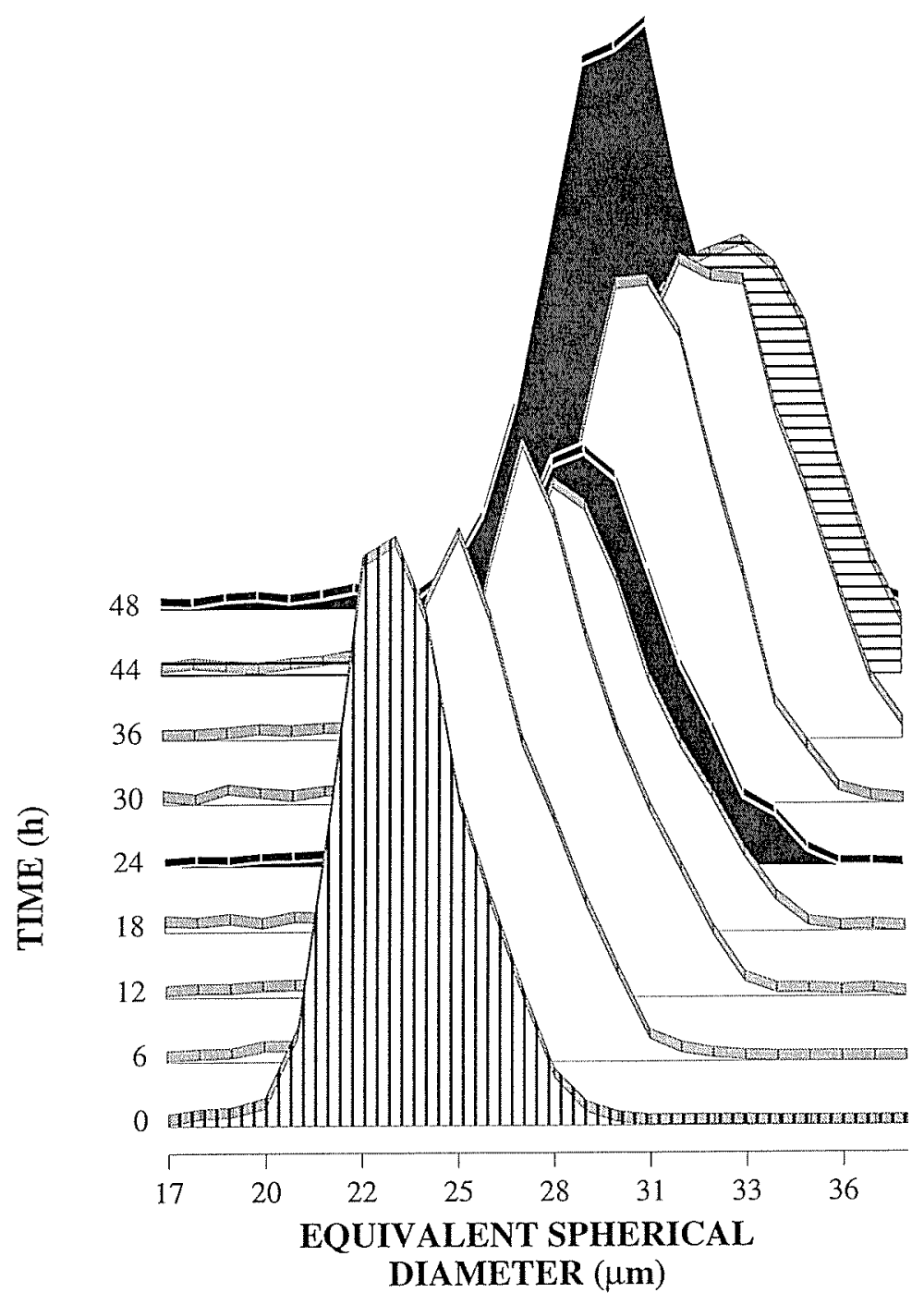


Fig. 3 Protein production in Alexandrium fundyense Balech (GtCA29) as a function of time and during synchronous growth on a light:dark cycle of 14:10 hours (dark periods indicated by shaded areas). Protein content was measured at 2-hour intervals (Error bars denote $\pm \mathrm{SD}$ ). 


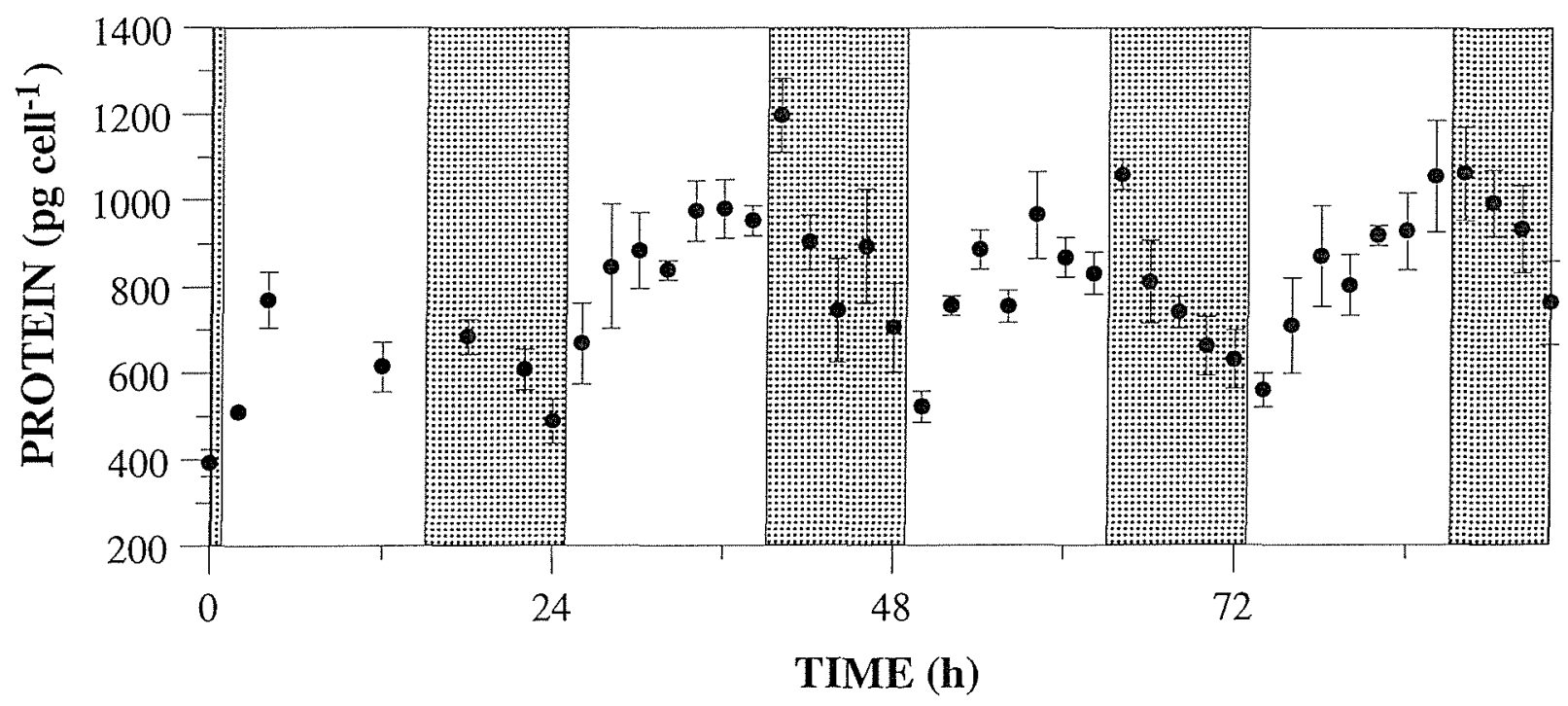


Fig. 4 Relative distributions of Alexandrium fundyense Balech (GtCA29) cells in the different cell cycle stages as a function of time and during synchronous growth on a light:dark cycle of 14:10 hours (dark periods indicated by shaded areas). The different cell cycle stage fractions represent the percentage of total cells in each phase and were determined by analysing the varying amounts of DNA per cell $(\mathrm{CV} \leq 5 \%)$. Error bars not shown for clarity. 


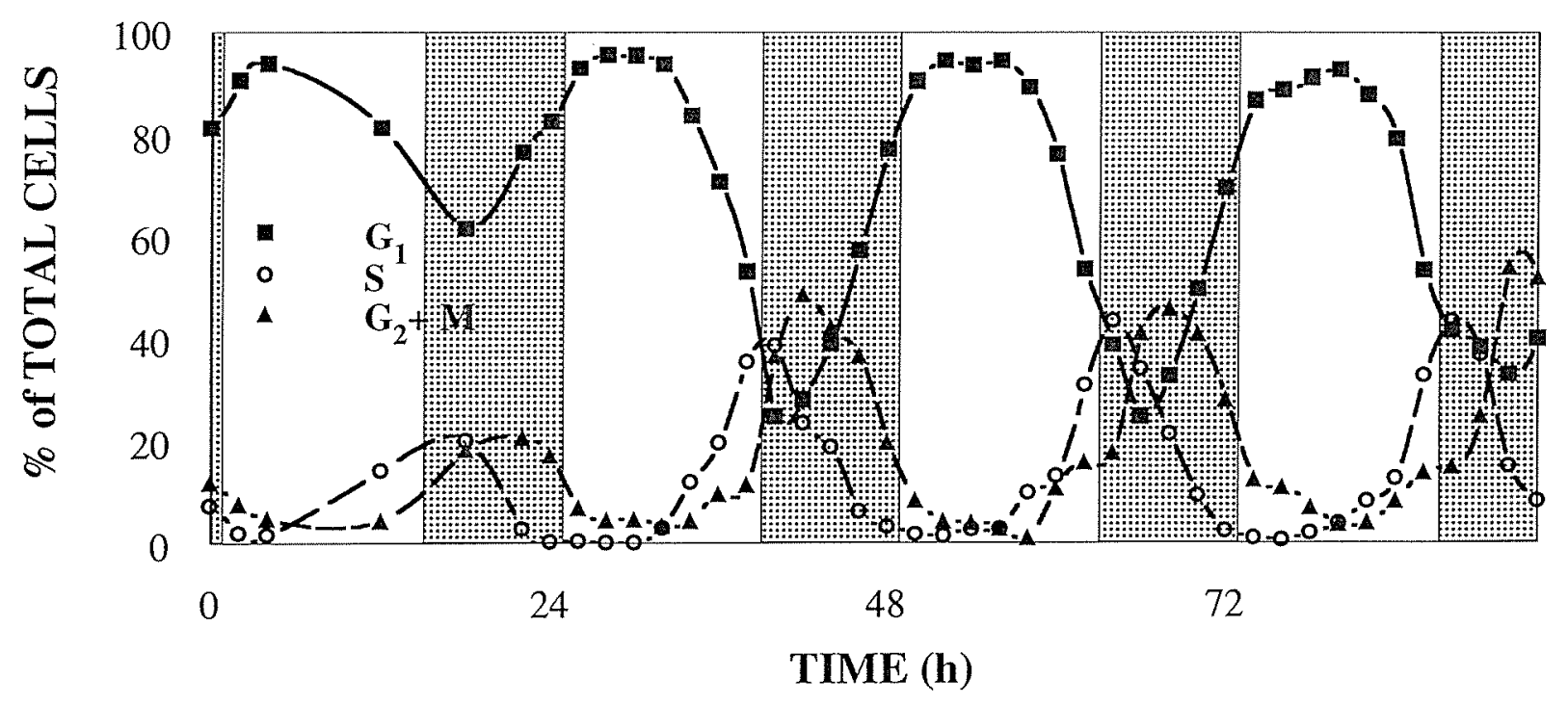


remainder of the cells) did not divide during the first 36 hours of the experiment. This larger cohort was arrested in what we can define as $\mathrm{G}_{0}$ based on DNA content, protein content, toxin content and cell size (see discussion). From the beginning of the second L:D cycle on (hr 26), the two populations progressed together through the rest of the cell cycles, as corroborated by the cell cycle patterns (Fig. 4), the cell size distributions (Fig. 2) and the regular increases in cell density (Fig. 1A).

The duration of the cell cycle phases was determined from the variations in DNA content over the duration of the experiment. Assuming that the cells that go first through one cell cycle stage are the ones also going first through the subsequent stages, and after determining the transition times between the peaks corresponding to the different phases (Beck 1978; Yamaguchi and Imai 1994), $\mathrm{G}_{1}$ was calculated to be approximately $16 \mathrm{hrs}$, the $S$ phase 2 hrs, and $G_{2}+M, 6$ hrs. Cells in $G_{2}$ and cells undergoing mitosis (M) have to be regarded as one group because their cytological differences cannot be resolved with flow cytometry.

Toxin Content. When the culture was removed from the dark and the normal light-dark cycle re-established, the total toxin in the culture (toxin $\mathrm{ml}^{-1}( \pm \mathrm{SD})$ ) increased from $32( \pm$ 8) $\mathrm{pmol} \mathrm{ml}^{-1}$ to $62.4( \pm 2.2) \mathrm{pmol} \mathrm{ml}^{-1}$ over a period of eight hours and then remained stable for 16 hours. Following this a new surge in toxin production was observed at the beginning of the light period at hr 25 . This increase continued for 8 hours, reaching a new constant level of $102.6( \pm 7.7) \mathrm{pmol} \mathrm{ml}^{-1}$. The same pattern of toxin increase and plateau was observed during the subsequent L:D cycles, with stable concentrations of $189( \pm 17.5)$ and $347.4( \pm 40.8) \mathrm{pmol} \mathrm{m}^{-1}$ respectively. The mean increase in concentration during each toxin production interval was $90 \%$. This pattern of toxin production coincides with the dynamics of toxin accumulation per cell as exemplified in Fig. 5 for hours 20 through 54. Toxin content per cell, as calculated from toxin concentrations in the culture and the 
corresponding cell densities, followed a regular pattern of increase, stabilization and decrease throughout each generation time.

Linear regressions were calculated for each of the segments described in the toxin $\mathrm{ml}^{-1}$ data. Only the sections delimited by hours $1-12,26-34,48-60$ and $72-82$ had slopes that were significantly different from zero $(\mathrm{p}<0.001)$. The horizontal, 'non-production' segments had slopes which were not statistically different from zero $(0.9>\mathrm{p}>0.57$, C.I. $89 \%$ ). These stepwise linear increases in toxin concentrations were modeled by fitting a simple, segmented and smoothed linear model to the data (see materials and methods). In this case, $\mathrm{X}$ was the parameter for toxin concentration (Fig. 1B). The fitted curve is plotted with the data in Fig. 1B.

Specific Toxin Production Rates. The specific toxin production rate, $\mu_{\text {Tox }}$, was defined as the change in toxin concentration relative to the existing concentration in the synchronized cultures. This definition is based on the previously described specific toxin production rate in asynchronous cultures, $\mu_{\mathrm{Tox}}\left(\right.$ day $^{-1}$ ) (Anderson et al. 1990b). The rates were obtained using the equation:

$$
\mu_{\mathrm{Tox}}=\frac{\ln \left(\frac{\mathrm{T}_{1}}{\mathrm{~T}_{0}}\right)}{t_{1}-t_{0}}
$$

where $\mu_{\text {Tox }}$ is the specific toxin production rate $\left(\mathrm{h}^{-1}\right)$ and $\mathrm{T}_{1}$ and $\mathrm{T}_{0}$ are the toxin concentrations at times $t_{1}$ and $t_{0}$ respectively, as obtained from the fitted curve in Fig. 1B. A regular pattern of toxin production, in which toxin production rates are positive for a period of approximately 8 hours and then drop to zero for the remaining 16 hours of the cell cycle, is revealed (Fig. 1C). 
Toxin composition. The relative proportions (mole percent of total toxin) of the five main saxitoxins remained essentially unchanged throughout the experiment (data not shown). The accumulation patterns of the seven main derivatives of saxitoxin, C2, NEO, STX, GTX2,3 isomers and GTX1,4 isomers, were very similar (Fig. 5). Analysis of the exact onset of accumulation for each of the toxins suggests that $\mathrm{C} 2$ increases first, followed by STX and the isomeric pair GTX 2,3. The concentrations of NEO and the pair GTX1,4 begin to increase approximately 1-2 hours later.

\section{DISCUSSION}

This study documents for the first time the extent to which the toxicity of the dinoflagellate Alexandrium fundyense varies on short (hourly) time scales. The fluctuations in toxin production were evaluated in the context of the cell cycle, a framework that allowed us to divide one cell generation into a series of shorter stages that could easily be delineated using DNA measurements. Synchronization of the cells ensured that virtually the entire population was in the same physiological state at each sampling point and therefore that the results of the analysis of the population as a whole could be extrapolated to the individual cell.

\section{Synchrony and growth patterns}

Immediately following release from the dark, Alexandrium shows a lag-phase equivalent to one generation time. Such non-proliferation periods, previously described for induced synchrony in yeast and other eukaryotes (Mitchison 1969; Pardee et al. 1978), are the result of a $\mathrm{G}_{0}$-like segment in the cell cycle that prevents the cells from progressing 
through $\mathrm{G}_{1}$ and dividing. The cells in this stage are of smaller size (Fig. 2). After a period of 24 hours the cells regain the normal size of about $30 \mu \mathrm{m}$ in diameter for this species (Fig. 2) with $96 \%$ of the cells being in $\mathrm{G}_{1}$ (Fig. 4). Over the following 24 hours cell size increases to reach a maximum during the peak of $\mathrm{G}_{2}$ (Figs. 2 and 4). Thereafter the cells decrease rapidly in size to values equivalent to $\mathrm{G}_{1}$ cells. The smaller size correlated to cells in $\mathrm{G}_{0}$ is never seen again during the experiment. These data suggest the presence of a sizedependent transition point at the end of $\mathrm{G}_{1}$, similar to other eukaryotes (Mitchison et al. 1991). The degree of synchrony achieved in the two subsequent divisions, as determined from the relative proportions of cells in the different cell cycle stages and the increase in cell numbers (Figs. 3 and 1A), was 100\% and 90\% respectively. Two further divisions (data not shown) show increments of $89 \%$ and $80 \%$. These numbers imply that even though synchrony was achieved during the first proliferation step, it was progressively lost. Similar patterns have been previously described for other eukaryotes such as yeast (Mitchison et al. 1991). The most widely accepted explanation for this loss of synchrony is the fact that the cells are growing at their maximum possible growth rate, a situation that is not sustainable as the cells are not in balanced growth, when uptake equals metabolic needs (Mitchison 1969). A similar situation is true for Alexandrium fundyense. This species usually grows at a rate of 0.3 to 0.5 divisions per day in culture, yet under the specific conditions of our experiment, the cells were forced into dividing once per day, a pace that is not sustainable over long periods of time. Such "explosive growth", events during which populations of organisms can grow very fast, are believed to be a possible mechanism for bloom formation (Smayda, pers. comm.).

\section{Temporal Pattern in Toxin Production}

In analyzing the variability in toxin production during this study, we chose to focus on 
Fig. 5 Changes in total toxin and toxin composition per cell of Alexandrium fundyense Balech (GtCA29) as a function of time and during synchronous growth on a light:dark cycle of 14:10 hours (dark periods indicated by shaded areas). The $\mathrm{Y}$-axis is discontinuous between 35 and $55 \mathrm{fmol} / \mathrm{cell}$. Error bars are not plotted for the single toxin derivatives for sake of clarity. 


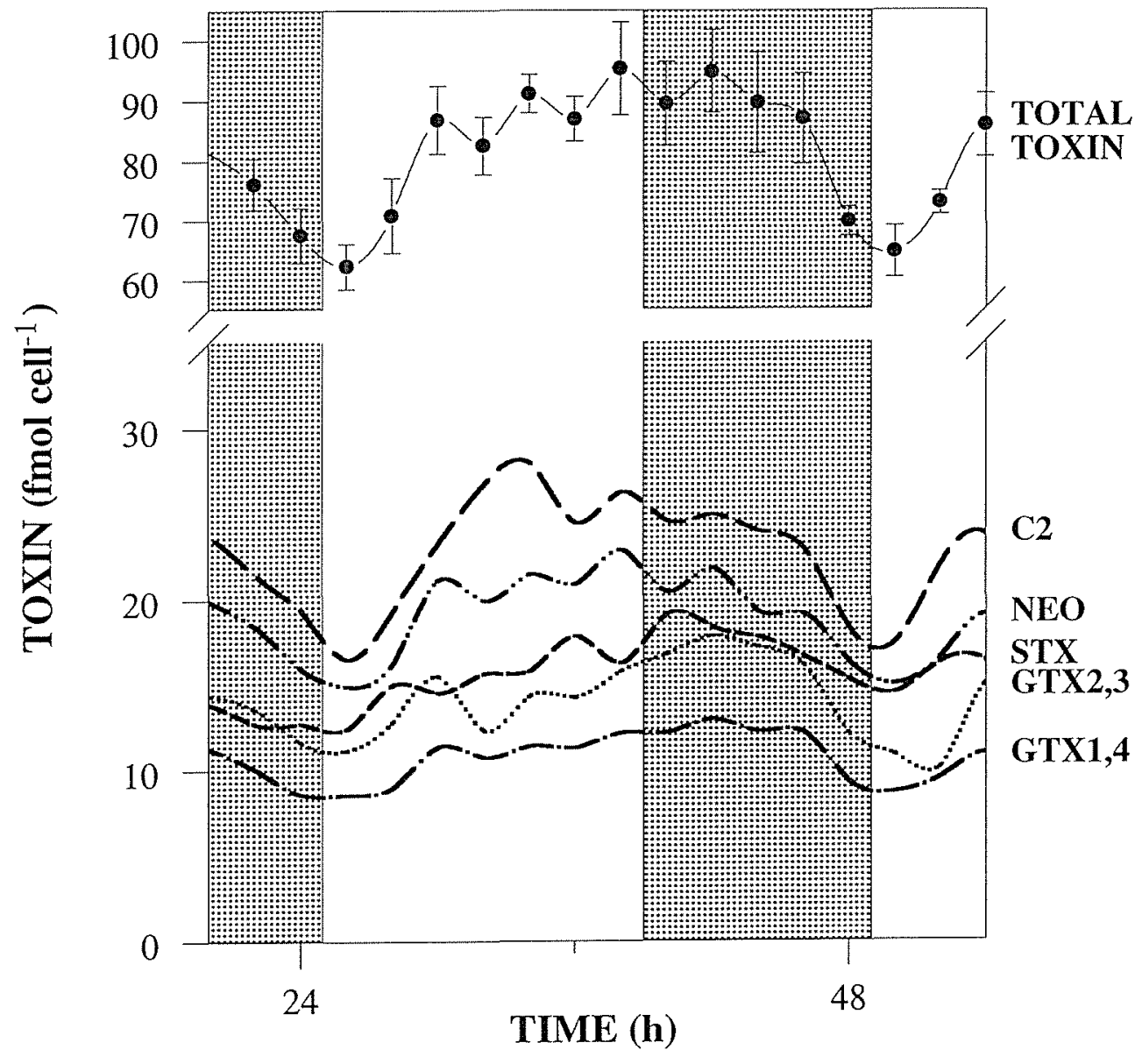


two parameters. First, the variations of toxin per unit volume of culture (toxin $\mathrm{ml}^{-1}$ ) were determined, for this parameter is an indicator of net toxin production and should never decrease unless toxin is catabolized or leaked from the cell. Secondly, toxin cell $^{-1}$ was derived from the previous data to follow the dynamics of toxin accumulation on a per cell basis (Note that we use the term "toxin production" to mean toxin accumulated in the cell, ignoring losses due to leakage or catabolism). The most important conclusion from the data presented here is that toxin production is induced by light and occurs in a defined interval within the $G_{1}$ phase of the cell cycle. Specific toxin production rates were positive for a period of eight to ten hours in early $G_{1}$ and remained zero for the remainder of the interphase and mitosis (Fig. 1C), six hours of which were still in light. This behaviour was not only observed once the population was synchronized, but also during the first 24 hours, when the cells were not yet progressing through the "regular" cell cycle.

If toxin were produced continuously and at a constant rate, toxin $\mathrm{ml}^{-1}$ should increase exponentially through time. In Fig. 1B, this would plot as a straight line with constant slope. Instead, the data reveal a step-like pattern similar in form to the steps seen in cell number when counted at closely spaced intervals through time (Fig. 1A). This is further confirmed when toxin accumulation per cell is analyzed, as exemplified in Fig. 5. Toxin accumulates (is produced) over a period of 8-10 hours before its concentration reaches a constant value. This level is maintained until the cells start dividing (Fig. 1A) and the toxin is most probably partitioned between the two daughter cells (Fig. 5), as toxin concentration in the culture does not change during mitosis (Fig. 1B). The average increase in toxin concentration over the duration of the experiment is exponential but is determined by an hourly scale, step-like pattern of toxin production. Such discontinuous production or activity patterns in synchronized cultures have been previously described in other organisms and are universal for cellular processes that are activated by external or internal 
factors rather than being continuous throughout the cell cycle (Mitchison 1969).

Given this discontinuous pattern of toxin production and increase in cell concentration, we decided to fit a segmented linear model to each of the data sets. The underlying assumption was that the production rate, similarly to the growth rate, follows a Gaussian distribution during the "accumulation" or "doubling" periods, resulting in a sigmoidal curve for the increase in toxin concentration or cell number (Mitchison 1969; Vaulot 1985). For simplicity purposes, such sigmoidal curves can be approximated by a straight line. The slope of this straight line would represent the mean production rate or growth rate during that period. Initially, the time points (parameter $\mathrm{T}$, see materials and methods) delimiting each segment of the cell or the toxin concentration curve on Figs. 1A and 1B respectively, were arbitrarilly defined at the times when the lights went on or off. After several iterations, the time intervals defining the segments were adjusted through a least-square, best-fit to the data. The duration and timing of each segment thus determined, closely matched the segments we had originally determined for calculating the slopes (Figs. 1A and 1B) and in the case of toxin production, the model also coincided with the patterns observed in toxin accumulation per cell (Fig. 5). These results confirmed the observation that toxin production occurred during an eight to twelve hour interval in early $\mathrm{G}_{1}$.

Specific toxin production rates were obtained using the values from the fitted curve in Fig. 1B. A regular pattern of toxin production is revealed in which toxin production rates are positive for a period of approximately 8-10 hours and then drop to zero for the remaining 16 hours of the cell cycle (Fig. 1C). In the three consecutive cycles we analyzed, toxin production was induced by light at the beginning of the light period and stopped approximately eight to ten hours into $\mathrm{G}_{1}$.

Protein production did not mimic toxin production throughout time (Fig. 3). Accumulation of soluble protein was also induced by light, but it continued during the light period and was reversed with the beginning of the dark period. Identical protein 
accumulation dynamics have been previously observed in other phytoplankton (Howell et al. 1977; Hastings et al. 1981; Puiseux-Dao 1981).

We conclude from these data that, unlike protein production, which extends over the entire interphase comprising $\mathrm{G}_{1}, \mathrm{~S}$ and $\mathrm{G}_{2}$ and is solely dependent on light, toxin production is induced by light, is confined to an early portion of the $\mathrm{G}_{1}$ phase only, and ceases before the light phase ends.

\section{Light Induction}

It has been postulated in a previous study that toxin production can be influenced by light. Alexandrium (=Protogonyaulax) tamarensis was shown to increase its toxicity when the growth rate was reduced by a decrease in light intensity (Ogata et al. 1987). This result is analogous to those obtained when growth rates are reduced as a result of nutrient limitation (Proctor et al. 1975; Hall 1982; Boyer et al. 1985; Anderson et al. 1990b) or temperature (Hall 1982; Ogata et al. 1987; Anderson et al. 1990b). Furthermore, a direct correlation between specific growth rates and specific toxin production rates during the exponential phase in semi-continuous cultures has been observed, suggesting a possible relationship between toxin production and the cell cycle (Anderson et al. 1990b). These observations can be explained taking into consideration our results that show that toxin production is clearly induced by light, lasts only for 8-10 hours and is confined to the early $\mathrm{G}_{1}$ phase (Figs. 1C and 4). Cells of the dinoflagellate Amphidinium carteri growing at a slow rate do so by increasing the duration of the $G_{1}$ phase while keeping the length of the other phases relatively constant (Olson and Chisholm 1986). If a cell is arrested in $\mathrm{G}_{1}$ for several light:dark cycles it would be conceivable for it to undergo several rounds of toxin synthesis before dividing, thereby increasing its toxin content and becoming more toxic. 


\section{Toxin Composition}

Another aspect of toxin production in A. fundyense is the relative composition of its toxin pool. It has been reported in the literature that the toxin composition of an individual isolate of Alexandrium remains constant under a variety of environmental conditions as well as through the different culture growth stages (Hall 1982; Boyer et al. 1987; Cembella et al. 1987; Ogata et al. 1987). Recently, however, it has been observed that significant changes in toxin composition can occur in cells exposed to different stresses. The relative abundance of STX in Alexandrium tamarense and A. catenella has been shown to decrease as the cells enter plateau phase and stop growing (Boczar et al. 1988). A. fundyense shows an increase in STX content at higher specific growth rates (Anderson et al. 1990a), which is consistent with Boczar et al.'s results (1988) for A. tamarense and A. catenella.

Our study also documents changes in toxin composition in A. fundyense, but these variations occurred at different time scales from those in previous studies. While the relative proportions (mole percent of total toxin) of the five main saxitoxins remained essentially unchanged throughout the experiment (data not shown), the accumulation

patterns (pmol cell-1) of the seven main derivatives of saxitoxin, C2, NEO, STX, GTX2,3 isomers and GTX1,4 isomers, showed slight variations with respect to the timing of formation (Fig. 5). Analysis of the exact onset of accumulation for each of the toxins suggests that C2 starts building up first, followed by STX and the isomeric pair GTX 2,3. With a delay of about one to two hours, the concentrations of NEO and the pair GTX1,4 begin to increase. A plausible interpretation of these results would involve a biosynthetic pathway consisting of one precursor centered around $\mathrm{C} 2$ and several subsequent transformation steps (Fig. 6). First, C2 would be transformed into GTX2,3 by means of an $N$-sulfatase. In a second step, GTX2,3 could be further transformed into STX by another sulfatase. Finally, a hydroxylase adds an $N$-hydroxy group to GTX2,3 and STX, 
Fig. 6 Putative sequence of events in the biosynthesis of STX and its derivatives. Continuous lines represent most likely interconversions, as deduced from Fig. 5 (see discussion). Dashed lines represent other possible paths. 


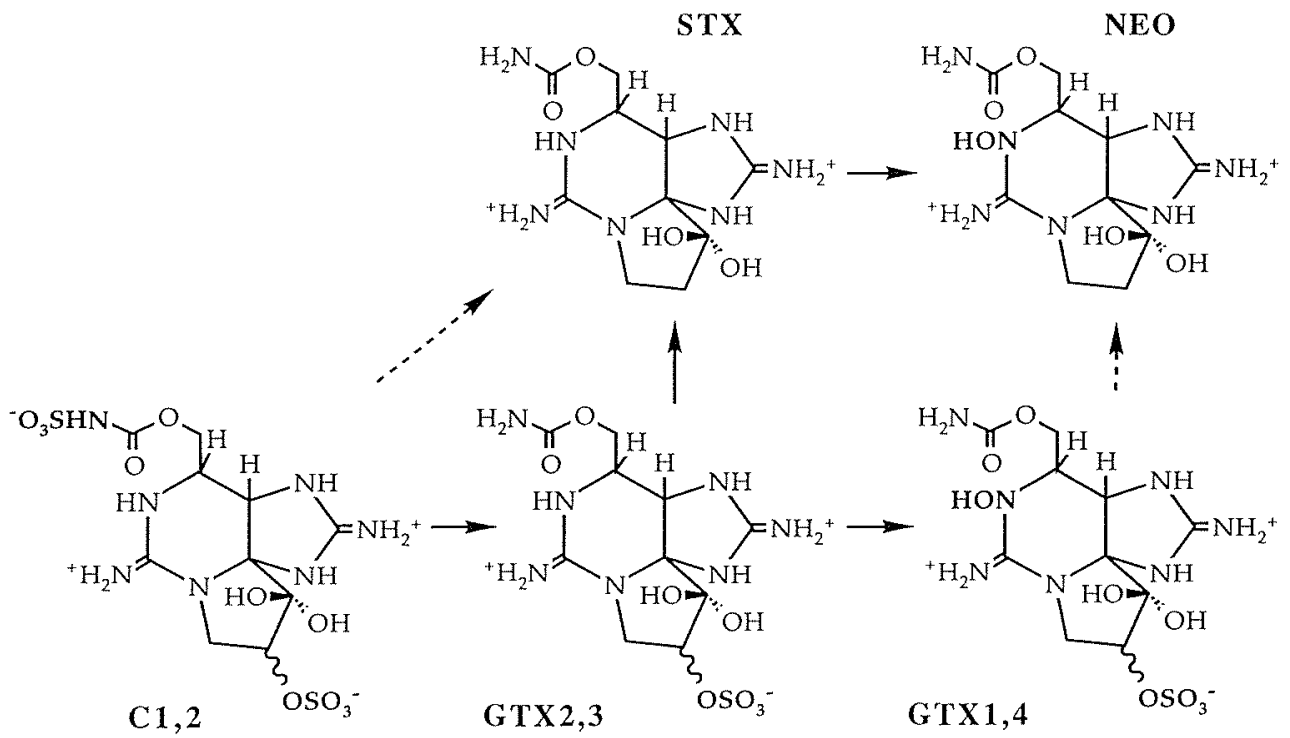


turning them respectively into GTX1,4 and NEO. The rough kinetics of the transformations, as derived from Fig. 5, would fit in such a putative scheme. These pathways are largely speculative at this stage. The synchronization of cultures and closely spaced toxin analysis shows promise for elucidating the kinetic profiles of the individual toxin productions.

A similar scheme of the STX biosynthetic pathway has been outlined before (Shimizu 1993), but no experimental evidence had been gathered prior to our study. This interpretation has to be carefully contrasted with observations of changes and variations in toxin composition in other dinoflagellate species such as Pyrodinium bahamense and Gymnodinium catenatum (Oshima et al. 1993; Usup et al. 1994). In these organisms, STX has been postulated to be a precursor or parent compound that is rapidly converted into NEO or GTX V, as these last two compounds are predominant and only negligible amounts of STX are detected (Oshima et al. 1993; Usup et al. 1994). In an integrated sheme of the STX biosynthetic pathway, interconversions among the toxins would be determined in part by the presence or absence of the appropriate enzymes, but actual toxin production would be the result of the accumulation of only one precursor or parent compound. This precursor could be one of the toxins or another unknown compound. Similar studies to this one using dinoflagellates that differ in their overall toxin composition are necessary to more conclusively elucidate the STX biosynthetic pathway.

\section{Cell Cycle}

The original purpose of this study was to investigate short term variability in toxicity in A. fundyense, yet it also revealed some interesting aspects of the cell cycle of this species and the manner in which the cells respond to prolonged darkness. DNA synthesis in dinoflagellates has been reported to be continuous throughout the cell cycle in several 
species (Karentz 1983; Rizzo 1987), or confined to a discrete S phase in others (Chang and Carpenter 1988; Yamaguchi 1992). A. fundyense clearly sinthesyzes DNA during a discrete time period, phased to a specific portion of the cell cycle (Fig. 4). This $\mathrm{S}$ phase takes place during the later portion of the light period and extends into the early dark period (Fig. 7).

An interesting observation relates to the presence of two cohorts of cells at the onset of the experiment and the subsequent homogeneity of the population several light:dark cycles later. This can be explained by the presence of two transition points in $\mathrm{G}_{1}$. Cells arrested at the first, light-dependent transition point (in early $\mathrm{G}_{1}$, immediately following mitosis) proceed through a $\mathrm{G}_{0}$-like period associated with lower metabolic activity and smaller size (Figs. 2 and 5). In addition, a small portion of the population (approx. 20\%) was apparently arrested at a transition point located further into $G_{1}$ and in this case sizedependent. These cells were slightly larger than the mean of the cells at the beginning of the experiment (Fig. 2) and account for the surge in $S$ phase and $G_{2}+M$ cells and the concurrent increase in cell concentration during the dark period of the first light:dark cycle (Figs. 1A and 3). Subsequently the entire population doubled over the next light:dark cycle. This means that all the cells had become synchronized and were proceeding through the cell cycle as a single unified cohort. In two subsequent light:dark cycles cell densities increased by a factor of 1.8 and 1.7 respectively (Fig. 1A). This might indicate a gradual loss of synchronicity in the culture, but, the cell cycle information showed in Fig 3 indicates that the level of synchronicity was still at approximately $96 \%$. Another explanation for the lack of complete doubling in cell numbers could be the loss of an undetermined number of cells from the sampled population. From the second day on we could observe a cell deposit at the bottom of all three carboys that was difficult to resuspend without damaging the cells. 
Fig. 7 Diagrammatic representation of cell cycle events in Alexandrium fundyense Balech (GtCA29) cells during synchronous growth on a light:dark cycle of 14:10 hours. Open bar: light phase; $\mathrm{G}_{1}$ : gap 1 (post mitotic); S: DNA synthesis phase; $\mathrm{G}_{2}$ : gap 2 (pre mitotic); M: mitosis. 


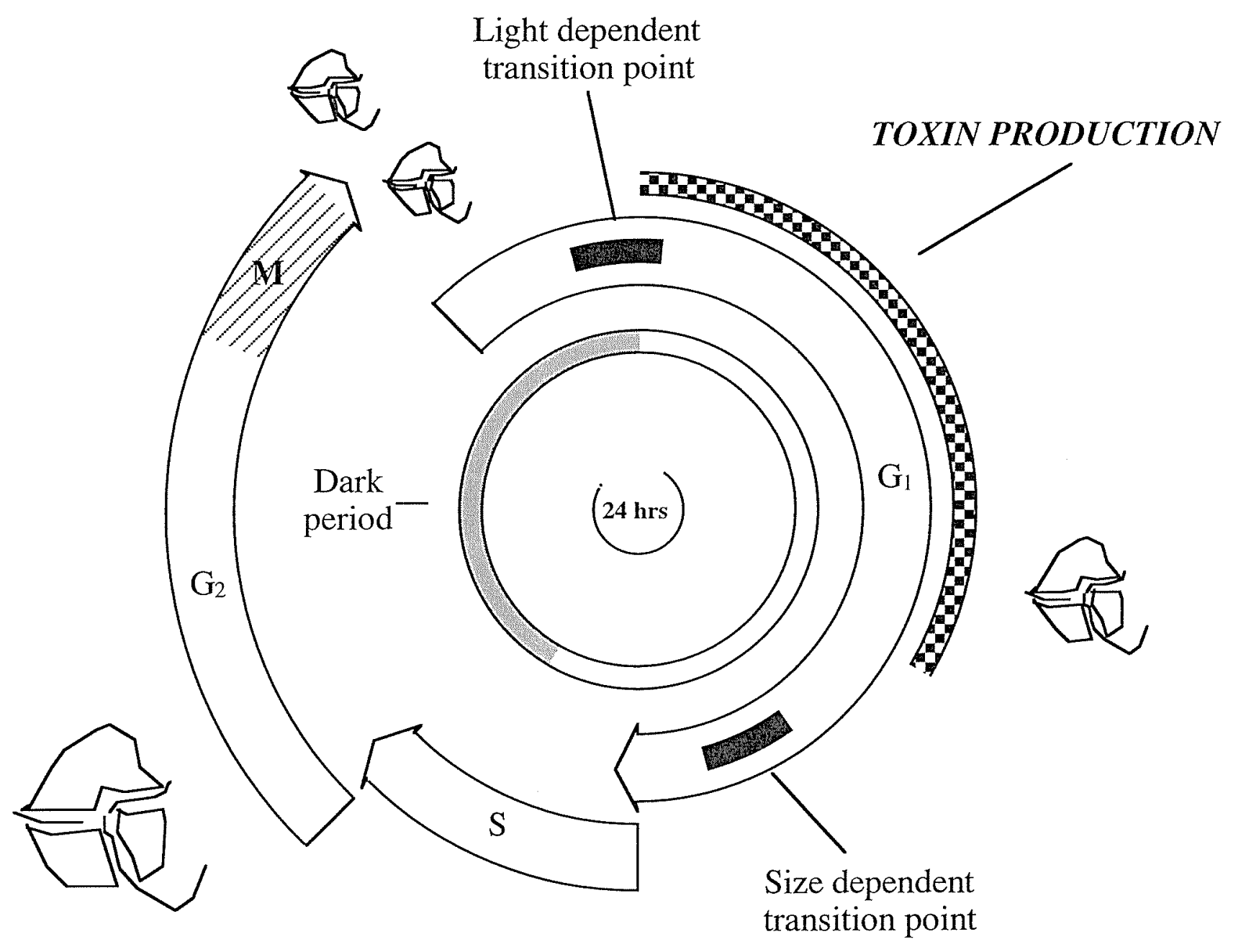


Single, light-dependent transition points in $\mathrm{G}_{1}$ have been identified in Chlamydomonas (Spudich and Sager 1980) and in Amphidinium carterii and Hymenomonas carterii (Olson and Chisholm 1986; Vaulot et al. 1986). Two light-dependent transition points have been characterized in Thalassiosira weisflogii, one in $\mathrm{G}_{1}$ and a second one in $\mathrm{G}_{2}$ (Vaulot et al. 1986). A single nutrient dependent control point located in $\mathrm{G}_{1}$ has also been identified in Prorocentrum minimum (Antia et al. 1990) and the simultaneous presence of nutrient dependent control points in $\mathrm{G}_{1}$ and in $\mathrm{G}_{2}$ has been described in Oxyrrhis marina (Whiteley et al. 1993). To our knowledge, the data presented here are the first evidence in phytoplankton suggesting that there may be two different transition points in $\mathrm{G}_{1}$, one of them light-, the other one size-dependent.

An alternative explanation for the existence of two cohorts of cells at the beginning of the experiment that does not require two transition points in $G_{1}$ is suggested by the cell cycle model of Klevecz (Klevecz 1976), who noted that certain mammalian cell lines had generation times that tended to be integer multiples of 4 hrs. In the Klevecz model, $\mathrm{G}_{1}$ is replaced by a loop called $\mathrm{G}_{\mathrm{q}}$ which has a duration equal to the quantized intervals between generation times. $\mathrm{G}_{\mathrm{q}}$ can thus be viewed as a subcycle from which the cells can reenter the remainder of the cell cycle, but only after completely traversing $\mathrm{G}_{\mathrm{q}}$ one or more times. Since exit from $\mathrm{G}_{\mathrm{q}}$ is regulated by environmental factors such as light, the net effect of prolonged darkness would be for a population of cells to be separated into two or more groups depending upon the number of $\mathrm{G}_{\mathrm{q}}$ subcycles they had traversed when darkness was imposed. Evidence for quantized generation times in the diatom Thalassiosira fluvialitis has been described, but the distribution of generation times for that species was not consistent with the Klevecz model (Chisholm and Costello 1980). In the case of $A$. fundyense, such a model cannot be dismissed, but the data presented here would imply a $\mathrm{G}_{\mathrm{q}}$ of 24 hours. Therefore, a model of the cell cycle that integrates a light-dependent and a 
size-dependent transition points seems to be the easiest way to explain our observations (Fig. 7).

\section{Summary}

The present study documents for the first time the dynamics of toxin production during the cell cycle of Alexandrium fundyense (Fig. 7). Toxin production was shown to occur over a discrete period during $\mathrm{G}_{1}$ and to be induced by light. The cell cycle contains two transition points responsible for regulating the passage of the cell through $\mathrm{G}_{1}$ (lightdependent), and the transition from $G_{1}$ to $S$ (size-dependent), respectively. We also suggest that $\mathrm{C} 2$ is the first derivative accumulating in the biosynthetic pathway of the toxins in our $A$. fundyense isolate, being subsequently transformed into the other toxins. The restriction of toxin production to a relatively short segment of the cell cycle provides a tool for comparing cells that are and are not synthesizing toxin. This has important implications with respect to the search for genes or enzymes involved in toxin production and their regulation in Alexandrium. In this context, work is in progress in our laboratory to identify toxin-specific genes by Differential Display analysis (Liang and Pardee 1992) of messenger-RNA components of cells harvested at different points during their cell cycle. In general, this work presented here shows how studying dinoflagellates at a high temporal resolution and under synchronized conditions can be useful in order to gain a broader understanding of their biochemistry and physiology. 


\section{ACKNOWLEDGEMENTS}

We would like to thank Zheng Lei for technical support during the experiment. This work was supported by grants from the National Science Foundation (OCE-8911226 and OCE-9415536) and a graduate research fellowship from "La Caixa", Spain (GTO). Contribution No. 9223 from the Woods Hole Oceanographic Institution.

\section{REFERENCES}

ANDERSON, D. M. 1989. Toxic algal blooms and red tides: A global perspective, p. 1116. In Okaichi, D. M. Anderson and Nemoto [ed.], Red tides: Biology, Environmental science, and toxicology. Elsevier Science Publishing.

- 1990. Toxin variability in Alexandrium species, p. 41-51. In E. Graneli, B.

Sundstrom, L. Edler and D. M. Anderson [ed.], Toxic marine phytoplankton. Elsevier Science Publishing.

- D. M. KULIS, G. J. DOUCETTE, J. C. GALlAGHER AND E. BALECH. 1994. Biogeography of toxic dinoflagellates in the genus Alxandrium from the northeastern United States and Canada. Mar. Biol. 120: 467-478.

,-- J. J. SULLIVAN AND S. HALL. 1990a. Toxin composition variations in one isolate of the dinoflagellate Alexandrium fundyense. Toxicon 28: 885-893.

,,--- AND C. LEE. 1990b. Dynamics and physiology of saxitoxin production by the dinoflagellates Alexandrium spp. Mar. Biol. 104: 511524.

ANTIA, J. R., E. J. CARPENTER AND J. CHANG. 1990. Species-specific phytoplankton growth rates via diel DNA synthesis cycles. Accuracy of growth rates 
measurement in the dinoflagellate Prorocentrum minimum. Mar. Ecol. Prog. Ser. 63: 273-279.

BECK, H. P. 1978. A new analytical method for determining duration of phases, rate of DNA synthesis and degree of synchronization data on synchronized cell populations. Cell Tissue Kinet. 11: 139-148.

BINDER, B. J. AND D. M. ANDERSON. 1990. Biochemical composition and metabolic activity of Scrippsiella trochoidea (dinophyceae) resting cysts. J. Phycol. 26: $289-298$.

BOCZAR, B. A., M. A. BEITLER, J. LISTON, J. J. SULLIVAN AND R. A. CATTOLICO. 1988. Paralytic shellfish toxins in Protogonyaulax tamarensis and Protogonyaulax catenella in axenic culture. P1. Physiol. Wash. 88: 1285-1290.

BOYER, G. L., J. J. SULLIVAN, R. J. ANDERSEN, P. J. HARRISON AND F. J. R. TAYLOR. 1987. Effects of nutrient limitation on toxin production and composition in the marine dinoflagellate Protogonyaulax tamarensis. Mar. Biol. 96: 123-128.

,-- , P. J. HARRISON AND F. J. R. TAYLOR. 1985. Toxin production in three isolates of Protogonyaulax sp., p. 281-286. In D. M. Anderson, A. W. White and D. G. Baden [ed.], Toxic Dinoflagellates. Elsevier.

CEMBELlA, A. D., J. J. SULLIVAN, G. L. BOYER, F. J. R. TAYLOR AND R. J. ANDERSEN. 1987. Variation in paralytic shellfish toxin composition within the Protogonyaulax tamarensis/catenella species complex: red tide dinoflagellates. Biochem. System. Ecol. 15: 171-186.

CHANG, J. AND E. J. CARPENTER. 1988. Species specific phytoplankton growth rates via diel DNA synthesis cycles. II. DNA quantification and model verification in the dinoflagellate Heterocapsa triquetra. Mar. Ecol. Prog. Ser. 44: 287-296. 
CHISHOLM, S. W. 1981. Temporal patterns of cell division in unicellular algae, p. 150181. In T. Platt [ed.], Physiological Bases of Phytoplankton Ecology (Can. Bull. Fish. Aqua. Sci., 210).

AND J. C. COSTELLO. 1980. Influence of environmental factors and population composition on the timing of cell division in Thalassiosira fluvialitis. J. Phycol. 16: 375-383.

GALLERON, C. AND A. M. DURRAND. 1976. Synchronization of the marine dinoflagellate Amphidinium carterii in dense cultures. J. Phycol. 12: 69-73.

GUILLARD, R. R. L. AND J. H. RYTHER. 1962. Studies of marine phytoplanktonic diatoms. Cyclotella nana Hustedt and Detonula confervacea (Cleve) Gran. Can. J. Microbiol. 8: 229-239.

HALL, S. 1982. Toxins and toxicity of Protogonyaulax from the northeast Pacific. Ph.D. thesis, Univ. of Alaska.

HALLEGRAEFF, G. M. 1993. A review of harmful algal blooms and the apparent global increase. Phycol. 32: 79-99.

HASTINGS, J. W., J. DUNLAP AND W. TAYLOR. 1981. Protein synthesis and protein turnover in circadian cycles, p. 519-529. In B. Horecker and E. Stadtman [ed.], Current topics in cellular regulation. vol. 18. Academic Press.

HOMMA, K. AND J. W. HASTINGS. 1988. Filtration-selection of cell cycle synchronized Gonyaulax polyedra: Quantized generation times. J. Biol. Rhythms 3: 49-58.

HOWELL, S. H., J. W. POSAKONY AND K. R. HILL. 1977. The cell cycle program of polypeptide labelling in Chlamydomonas reinhardtii. J. Cell Biol. 72: 223-230.

JOHNSTON, G. C., R. A. SINGER, S. O. SHARROW AND M. L. SLATER. 1980. Cell Division in the yeast Saccharomyces cerevisiae growing at different rates. J. Gen. Microbiol. 118: 479-484. 
KARENTZ, D. 1983. Patterns of DNA synthesis and cell division in marine dinoflagellates. J. Protozool. 30: 581-588.

KLEVECZ, R. R. 1976. Quantized generation time in mammalian cells as an expression of the cellular clock. Proc. Natl. Acad. Sci. USA 73: 4012-4016.

LIANG, P. AND A. B. PARDEE. 1992. Differential display of eukaryotic messenger RNA by means of the polymerase chain reaction. Science 257: 967-971.

MARANDA, L., D. M. ANDERSON AND Y. SHIMIZU. 1985. Comparison of toxicity between populations of Gonyaulax tamarensis of eastern North American waters. Estuar. Coast. Shelf Sci. 21: 401-410.

MITCHISON, J. M. 1969. Enzyme synthesis in synchronous cultures. Science 165: 657-663.

—, J. CREANOR AND B. NOVAK. 1991. Coordination of growth and division during the cell cycle of fission yeast. Cold Spring Harb. Symp. Quant. Biol. 56, The Cell cycle: 557-565.

OGATA, T., M. KODAMA AND T. ISHIMARU. 1987. Toxin production in the dinoflagellate Protogonyaulax tamarensis. Toxicon 25: 923-928.

OLSON, R. J. AND S. W. CHISHOLM. 1986. Effects of light and nitrogen limitation on the cell cycle of the dinoflagellate Amphidinium carteri. J. Plankton Res. 8: 785793.

— D. VAULOT AND S. W. CHISHOLM. 1986. Effects of environmental stresses on the cell cycle of two marine phytoplankton species. Plant Physiol. 80: 918-925.

OSHIMA, Y., S. I. BLACKBURN AND G. M. HALLEGRAEFF. 1993. Comparative study on paralytic shellfish toxin profile of the dinoflagellate Gymnodinium catenatum from thre different countries. Mar. Biol. 116: 471-476. 
— K. SUGINO AND T. YASUMOTO. 1989. Latest advances in HPLC analysis of paralytic shellfish toxins. Seventh international IUPAC symposium on mycotoxins and phycotoxins 319-326.

PARDEE, A. B., R. DUBRON, J. L. HAMLIN AND R. F. KLEVTZIEN. 1978. Animal cell cycle. Ann. Rev. Bochem. 47: 715-750.

PRESCOTT, D. M. 1976. Reproduction in eukaryotic cells. Academic Press.

PROCTOR, N. H., S. L. CHAN AND A. J. TREVOR. 1975. Production of saxitoxin by cultures of Gonyaulax catenella. Toxicon 13: 1-9.

PUISEUX-DAO, S. 1981. Cell-cycle events in unicellular algae, p. 130-149. In T. Platt [ed.], Physiological Bases of Phytoplankton Ecology (Can. Bull. Fish. Aqua. Sci., 210).

RIZZO, P. J. 1987. Biochemistry of the dinoflagellate nucleus, p. 143-173. In F. J. R. Taylor [ed.], The Biology of dinoflagellates. Blackwell Sci. Publ.

- 1991. The enigma of the dinoflagellate chromosome. J. Protozool. 38: 246-252. RODRIGUEZ, M., J. W. CHO, H. W. SAUER AND P. J. RIZZO. 1994. Evidence for the presence of $c d c 2$-like protein kinase in the dinoflagellate Cryptecodinium cohnii. Journal of Eukaryotic Microbiology 40: 91-96.

SHIMIZU, Y. 1993. Microalgal metabolites. Chem. Rev. 93: 1685-1698.

SPUDICH, J. AND R. SAGER. 1980. Regulation of Chlamydomonas Cell Cycle by light and dark. J. Cell Biol. 85: 136-145.

USUP, G., D. M. KULIS AND D. M. ANDERSON. 1994. Growth and toxin production of the toxic dinoflagellate Pyrodinium bahamense Var. compressum in laboratory cultures. Nat. Tox. 2: 254-262.

UTERMÖHL, H. 1958. Neue Wege in der quantitativen Erfassung des Planktons (mit besonderer Berücksichtigung des Ultraplanktons). Verh. int. Ver. theor. angew. Limnol. 5: 567-596. 
VAN DOLAH, F. M., T. A. LEIGHFIELD, H. D. SANDEL AND C. K. HSU. 1995. Cell division in the dinoflagellate Gambierdiscus toxicus is phased to the diurnal cycle and accompanied by activation of the cell cycle regulatory protein cdc2 kinase. J. Phycol. 31: 395-400.

VAULOT, D. 1985. Cell cycle controls in marine phytoplankton. Ph.D. thesis, WHOI/MIT, Thesis,

—, R. J. OLSON AND S. W. CHISHOLM. 1986. Light and dark control of the cell cycle in two marine phytoplankton species. Exp. Cell Res. 167: 38-52.

WHITE, A. W. 1978. Salinity effects on growth and toxin content of Gonyaulax excavata, a merine dinoflagellate causing paralytic shellfish poisoning. J. Phycol. 14: 475-479.

WHITELEY, A. S., P. H. BURKILL AND M. A. SLEIGH. 1993. Rapid method for cell cycle analysis in a predatory marine dinoflagellate. Cytometry 14: 909-915.

YAMAGUCHI, M. 1992. DNA synthesis and the cell cycle in the noxious red-tide dinoflagellate Gymnodinium catenatum. Mar. Biol. 112: 191-198.

AND I. IMAI. 1994. A microfluorometric analysis of nuclear DNA at different stages in the life history of Chattonella antiqua and Chattonella marina (Raphidopyceae). Phycol. 33: 163-170. 


\section{CHAPTER II}

Coupling of saxitoxin biosynthesis to the $G_{1}$ phase of the cell cycle in the dinoflagellate Alexandrium fundyense: temperature and nutrient effects 


\section{ABSTRACT}

The linkage between changes in the length of cell cycle stages and the toxicity of Alexandrium fundyense Balech were studied in semi-continuous cultures. Growth rates ranging from $0.031 \mathrm{~d}^{-1}$ to $0.36 \mathrm{~d}^{-1}$, were established at different temperatures or levels of phosphate limitation. In all temperature and phosphate limitation treatments, $\mathrm{G}_{1}$ was always the phase with the longest duration. Decrease in growth rate was associated with an increase in duration of the different cell cycle stages, $G_{1}$ and $G_{2}+M$ showing the most variation relative to the respective increase in generation time and $\mathrm{S}$ the stage showing the least. Over the range of temperatures studied $\left(20^{\circ} \mathrm{C} \rightarrow 8^{\circ} \mathrm{C}\right)$, the duration of $\mathrm{G}_{1}$ doubled, that of $\mathrm{G}_{2}+\mathrm{M}$ increased by a factor of 2.7 and that of $\mathrm{S}$ by 3.8. Over the range of growth rates studied under phosphate limitation $(0.36 \rightarrow 0.031)$, the duration of $\mathrm{G}_{1}$ increased by a factor of 5.3 , that of $\mathrm{G}_{2}+\mathrm{M}$ by 43 and that of $\mathrm{S}$ by 10 . The temperature treatments demonstrated a direct correlation between length of the cell cycle, and more particularly, duration of the $G_{1}$ phase, with toxin content (= toxin cell quota). Under phosphatelimiting conditions the same correlation with $G_{1}$ duration was observed, along with a clear uncoupling of toxin accumulation from the $S$ and $G_{2}$ phases of the cell cycle. In both the temperature treatments and the phosphate limitation experiments, toxin production rates remained constant for the respective range of conditions, implying that the variations in toxin content observed were a result of increasing periods of biosynthetic activity. Toxin accumulation was directly correlated to protein biosynthesis in all temperature treatments. In contrast, toxin content showed little correlation with protein content as phosphate limitation increased. Significant differences in toxin composition were observed between the temperature and phosphate treatments: Total concentrations of GTX II and III and C I and II were significantly higher in the phosphate-limited cultures, while the levels of STX, NEO and gonyautoxins I and IV remained virtually unchanged. We conclude that toxin 
biosynthesis in A. fundyense is coupled to the $\mathrm{G}_{1}$ phase of the cell cycle, that toxin synthesis is not down-regulated by phosphate deprivation and that interconversions among saxitoxin derivatives are influenced by the availability of phosphate. These data confirm earlier observations that toxin production is discontinuous over the cell cycle of $A$. fundyense and shed new light on the role of phosphate in the biosynthetic pathway. 


\section{INTRODUCTION}

Dinoflagellates in the genus Alexandrium are responsible for outbreaks of Paralytic Shellfish Poisoning (PSP) in temperate coastal areas around the world (Anderson, 1989). PSP is caused by saxitoxin (STX) and its over twenty known derivatives, a group of highly nitrogenous alkaloids with a marked affinity and blocking capacity for sodium channels (Shimizu, 1993). STX is biosynthesized by Alexandrium sp. and subsequently accumulates in bivalves filter-feeding on the dinoflagellate; ingestion of these toxic shellfish causes PSP symptoms at higher levels of the trophic chain, including humans (Sommer et al., 1937). Knowledge of the mechanism of toxin biosynthesis and its regulation in dinoflagellates is crucial for a complete understanding of this phenomenon.

Considerable work has been done on the influence of growth-limiting physico-chemical factors such as nutrient concentrations, light and temperature on the ecophysiology of this genus and its capacity to produce toxins (Proctor et al., 1975; White, 1978; Hall, 1982; Boyer et al., 1987; Ogata et al., 1987; Anderson et al., 1990b; Flynn et al., 1994; Matsuda et al., 1996). Under nitrogen starvation, light limitation or non-optimal salinity conditions, toxin content (= toxin cell quota) is reduced concomitantly with a decrease in the availability of the limiting factor. Only in the case of phosphate starvation and temperature limitation has the contrary been observed - an increase in toxin content with increasing stress. Phosphorus is incorporated into four main organic compound fractions in the cells: RNA, DNA, and phosphorus included in lipids and in esters that have a direct bearing on cell metabolism. Furthermore, phosphates play an important metabolic role as substrates for the fine regulation of biochemical activity in the cells via protein kinases (Pardee $e t$ al., 1978). Temperature is a general modulator of growth and biosynthetic rates in phytoplankton and can therefore influence the accumulation of specific metabolites (Jitts et al., 1964). 
In addition to changes in the toxin content, toxin composition (i.e., the absolute or relative amounts of the different STX derivatives present in the organism) has also been shown to vary under different limiting conditions (Boczar et al., 1988; Anderson et al., 1990a; MacIntyre et al., 1997). These variations are a result of physiological changes that regulate the sequence of transformations leading to the different derivatives. These pathways have not yet been elucidated. Only recently have several enzymes involved in specific interconversions among STX derivatives been characterized, but the information is still fragmented with respect to the sequence of interconversions (Oshima, 1995; Yoshida et al., 1996). Observation of accumulation patterns for the different STX derivatives in synchronized cultures of $A$. fundyense suggests a sequence and directionality to these interconversions beginning with C I and II (Taroncher-Oldenburg et al., 1997), but no specific pathway has yet been outlined, as the direct precursor or parent compound for the series of the STXs has not been determined. The sequence of interconversions cannot be rooted at a specific origin or parent compound with our present knowledge (Shimizu, 1993).

In parallel to the influence of the above-mentioned environmental factors on toxin production, a more immediate effect of limiting conditions has been observed on the growth rate of toxic dinoflagellates (Proctor et al., 1975; White, 1978; Hall, 1982; Watras et al., 1982; Anderson et al., 1990b; Matsuda et al., 1996). The general trend in this case is a reduction in growth rate with an increase in the limitation or stress. It has further been documented for several groups of phytoplankton that such changes in growth rate are tightly correlated to changes in the duration of the different cell cycle stages (Vaulot, 1985; Olson and Chisholm, 1986; Cetta and Anderson, 1990). Depending on the organism, changes in the doubling time can be reflected in changes in the duration of specific phases of the cell cycle (Guiget et al., 1984; Olson et al., 1986; Yamaguchi and Honjo, 1989). 
The eukaryotic cell cycle is divided into four main stages. Following the mitotic division of the mother cell, the two daughter cells undergo a first period called $\mathrm{G}_{1}$, during which they synthesize essential cell constituents and grow in size. Once appropriate internal and external conditions are met the cell commits to a new division. This process follows three steps: First, the cells replicate their DNA, thereby doubling their genetic information, during the $S$ phase. A second metabolically active period follows, called $\mathrm{G}_{2}$, in preparation for the final phase, mitosis, M, during which cells undergo cytokinesis and divide their genetic information among their offspring. Progression through the cell cycle is highly influenced by environmental conditions, as these determine the metabolic and energetic status of the cell (Yamaguchi and Honjo, 1989). Cells will grow slower if their metabolism is not optimal and a successful division process is compromised (Pardee et al., 1978). Conversely, metabolic processes regulated by cell cycle events will also be affected.

In algae, biochemical pathways such as DNA synthesis and a variety of specific enzyme activities are modulated in a periodic, cell cycle dependent fashion (Kates and Jones, 1967; Vassef et al., 1973; Forde and John, 1974). These biosynthetic pathways are influenced by conditions affecting normal progression through the cell cycle (Mitchison, 1969; Mitchison et al., 1991). The lengthening of a specific cell cycle stage will thus result in longer metabolic activities and hence higher product accumulations. In the case where the pathway of interest is only influenced by the cell cycle dynamics and no other factors, this would translate into a constant ratio between the concentration of the metabolite and the length of the cell cycle phase of interest. This is equivalent to the existence of a constant cell cycle-specific production rate of the compound.

Previous studies have shown an inverse correlation between growth rate and toxin content in A. tamarense (Proctor et al., 1975; Ogata et al., 1987) and a direct correlation between specific growth rate and specific toxin production rate in the closely related 
organism A. fundyense (Anderson et al., 1990b). We have also shown that toxin production is discontinuous and restricted to a portion of the $\mathrm{G}_{1}$ phase of the cell cycle in synchronously growing $A$. fundyense (Taroncher-Oldenburg et al., 1997). These results lead us to the conclusion that there should be a correlation between the rates of toxin production or toxin accumulation and length of $\mathrm{G}_{1}$. The aim of this study was to determine if there is any direct correlation between variations in toxin production, measured as accumulation of saxitoxin in a cell, and changes in duration of the different stages of the cell cycle under different conditions that affect growth rate and thus cell cycle progression. Such a correlation would confirm that STX biosynthesis is discontinuous and restricted to the $\mathrm{G}_{1}$ cell cycle stage.

\section{MATERIALS AND METHODS}

The organism. The dinoflagellate Alexandrium fundyense (strain GtCA29) was used throughout this study. A culture was established in January 1985 from a cyst isolated from Gulf of Maine sediments, 20 miles east of Portsmouth, New Hampshire (USA). That culture was used to isolate a single cell to establish a clonal culture. Prior to the experiments, cultures were maintained at $15^{\circ} \mathrm{C}$ in $\mathrm{f} / 2$ medium (Guillard and Ryther, 1962) modified by addition of $\mathrm{H}_{2} \mathrm{SeO}_{3}\left(10^{-8} \mathrm{M}\right)$ and by reducing the concentration of $\mathrm{CuSO}_{4}$ to $10^{-8} \mathrm{M}$. Vineyard Sound seawater $(0.2 \mu \mathrm{m}$ filtered, $31 \%$ salinity $)$ was used as the

medium base. Throughout the experiments, irradiance of ca. $250 \mu \mathrm{Em}^{-2} \mathrm{~s}^{-1}$ was provided by cool white fluorescent bulbs on a $14: 10 \mathrm{~h}$ light:dark cycle.

Temperature experiment with semi-continuous cultures. Effects of temperature on toxin content, toxin composition, protein content and cell cycle phase lengths were studied 
using a temperature-gradient bar (Watras et al., 1982), in which a range of seven different temperatures $\left(8^{\circ} \mathrm{C}, 10^{\circ} \mathrm{C}, 11^{\circ} \mathrm{C}, 13^{\circ} \mathrm{C}, 15^{\circ} \mathrm{C}, 17^{\circ} \mathrm{C}\right.$ and $20^{\circ} \mathrm{C}$ ) was established (Table 1 ). Twenty eight $25 \times 150 \mathrm{~mm}$ culture tubes containing $25 \mathrm{ml}$ of sterile filtered $\mathrm{f} / 2$ medium were inoculated with exponentially growing cells and acclimated, four per treatment, to each temperature over two transfer cycles. Growth was monitored throughout the experiment using in vivo fluorescence measurements obtained on a Turner Designs model 10 fluorometer (Turner Designs, Sunnyvale, Ca). Semi-continuous cultures were established after specific growth rates were determined for the different temperatures. Following the second transfer, these rates were used as the respective daily dilution rates of fresh medium for each treatment in order to maintain a constant cell density in the cultures over a period of twelve days. The cell densities ranged from 6,000 cells $\mathrm{ml}^{-1}$ at $8^{\circ} \mathrm{C}$ to about 8,000 cells $\mathrm{ml}^{-1}$ at $20^{\circ} \mathrm{C}$. At the end of the experiment, the four tubes per temperature were combined, two by two. The resulting two samples per treatment were then harvested and aliquots prepared for toxin, DNA and protein analysis.

Low phosphate experiment with semi continuous cultures. To study the effect of phosphate limitation on toxin content, toxin composition, protein content and cell cycle, semi-continuous cultures of $A$. fundyense were established at $20^{\circ} \mathrm{C}$ and in $\mathrm{f} / 2$ medium in which the concentration of $\mathrm{PO}_{4}{ }^{3-}$ was lowered from $36 \mu \mathrm{M}$ to $1.8 \mu \mathrm{M}$ (f/40 $\left[\mathrm{PO}_{4}{ }^{3-}\right]$ ). Five different dilution rates were applied to the different cultures, four per treatment, in order to provide five different phosphate limited growth rates $(0.5,0.25,0.1,0.075$ and 0.05 divisions per day) (Table 1). Growth was monitored throughout the experiment using in vivo fluorescence measurements obtained on a Turner Designs model 10 fluorometer. After two transfers the cultures were kept at a cell density of approximately $3,000 \mathrm{cells} \mathrm{ml}^{-1}$ for a twelve day period, following which, the four tubes per dilution rate were combined, 
two by two. The resulting two samples per treatment were then harvested and aliquots prepared for toxin, DNA and protein analysis.

Flow cytometric analysis of DNA. Ten $\mathrm{ml}$ aliquots of culture were preserved with $5 \%$ formalin $(\mathrm{v} / \mathrm{v})$ and stored at $4^{\circ} \mathrm{C}$. The cells were centrifuged $\left(1700 \mathrm{xg}, 23^{\circ} \mathrm{C}, 3\right.$ mins) and the pellet resuspended in $10 \mathrm{ml}$ of ice cold methanol and stored at $4^{\circ} \mathrm{C}$ to extract chlorophyll. The samples were then further concentrated by centrifugation. A subsample of the methanol-preserved material was transferred into a $1.5 \mathrm{ml}$ microcentrifuge tube and pelleted at $2000 \mathrm{rpm}$. The supernatant was removed and the cells washed with $1 \mathrm{ml}$ PBS (40mM Na $\left.2 \mathrm{HPO}_{4}, 22 \mathrm{mM} \mathrm{KH}_{2} \mathrm{PO}_{4}, 85 \mathrm{mM} \mathrm{NaCl}\right)$. After centrifugation, the pellet was resuspended in $0.5 \mathrm{ml}$ propidium iodide (PI) staining solution $\left(4 \mu \mathrm{g} \mathrm{ml}^{-1} \mathrm{PI}, 1250\right.$ units RNase $\mathrm{ml}^{-1}$ ) and allowed to react in the dark for at least two hours prior to analysis on an Epics V flow cytometer (Coulter Electronics, Hialeah, FL) (Olson et al., 1986). The proportions of cells in $G_{1}, S$ and $G_{2}+M$ were determined as described elsewhere (Cetta and Anderson, 1990). The duration of the cell cycle stages was calculated using the equations of Slater et al (Slater et al., 1977):

$$
\begin{aligned}
& T\left(\mathrm{G}_{1}\right)=-\left(t_{\mathrm{D}} / \ln 2\right) \ln \left(1-\left[P\left(\mathrm{G}_{1}\right) / 2\right]\right) \\
& T(\mathrm{~S})=\left(t_{\mathrm{D}} / \ln 2\right) \ln \left(1+P(\mathrm{~S}) /\left[1+P\left(\mathrm{G}_{2}\right)\right]\right) \\
& T\left(\mathrm{G}_{2}\right)=\left(t_{\mathrm{D}} / \ln 2\right) \ln \left(1+P\left(\mathrm{G}_{2}\right)\right)
\end{aligned}
$$

where $T(\mathrm{x})$ is the duration of each cell cycle stage, $t_{\mathrm{D}}$ represents the doubling time of the population under balanced growth conditions and $P(\mathrm{x})$ is the proportion of cells in each specific cell cycle stage. 
Toxin Analysis. Between 1.5 and $2.5 \times 10^{5}$ cells were collected by centrifugation $\left(3,000 \times \mathrm{g}, 23^{\circ} \mathrm{C}\right)$. The resulting pellet was rinsed into a centrifuge tube and resuspended in $0.5 \mathrm{M}$ acetic acid for extraction by sonification. The extracts were stored at $-20^{\circ} \mathrm{C}$ prior to analysis. The extracts were analyzed by HPLC (Oshima et al., 1989) incorporating the modifications previously described by Anderson et al. (Anderson et al., 1994).

Soluble Protein. Approximately 30,000 cells were collected by centrifugation ( $3000 \mathrm{x}$ $\mathrm{g}, 23^{\circ} \mathrm{C}$ ) for protein quantification. After aspiration of the supernatant, the pellet was stored frozen at $-20^{\circ} \mathrm{C}$. For analysis, $1 \mathrm{ml}$ of $0.1 \mathrm{~N} \mathrm{NaOH}$ was added to the pellet and the suspension sonified for 15 seconds to disrupt the cells. Samples were then digested for 20 $\min$ at $80^{\circ} \mathrm{C}$, centrifuged, and the supernatant removed and neutralized with 0.1 volumes of $1.0 \mathrm{~N} \mathrm{HCl}$ (Binder and Anderson, 1990). A $50 \mu 1$ fraction of the neutralized solution was mixed with $1 \mathrm{ml}$ of bicinchoninic acid (BCA) working solution (Pierce, Rockford IL), and the absorbance of duplicate samples determined at $562 \mathrm{~nm}$.

Abbreviations used throughout this text are: STX = saxitoxin; $\mathrm{NEO}=$ neosaxitoxin; GTX $1,2,3,4,5=$ gonyautoxins I, II, III, IV and V; C2 $=$ toxin $C 2 ; \mathrm{G}_{0}, \mathrm{G}_{1}$ and $\mathrm{G}_{2}=\mathrm{Gap}$ 0 , Gap 1 and Gap 2 phases of the cell cycle; $\mathrm{S}=$ synthesis phase; $\mathrm{M}=$ mitosis.

\section{RESULTS}

Growth and Cell Cycle Dynamics. The growth rate of A. fundyense decreased as temperatures decreased (Table 1). The slope obtained from a linear regression of growth rate against temperature $\left(a=-1.65 ; R^{2}=0.93\right)$ matched the slope of a theoretical curve $(a=-$ 
Table 1. Growth rates of Alexandrium fundyense grown in semi-continuous culture under phosphate limitation or at different temperatures.

\begin{tabular}{lll}
\hline Temperature $\dagger$ & $\begin{array}{l}\mathrm{PO}_{3}{ }^{-} \text {limited } \\
\text { cultures } \ddagger\end{array}$ & Growth rate $\S$ \\
$\left({ }^{\circ} \mathrm{C}\right)$ & dil. rate $\left(\right.$ day $\left.^{-1}\right)$ & $\mu\left(\right.$ day $\left.^{-1}\right)$ \\
\hline 20 & & 0.277 \\
17 & & 0.24 \\
15 & & 0.194 \\
13 & & 0.186 \\
11 & & 0.18 \\
10 & 0.15 \\
8 & 0.17 & 0.121 \\
20 & 0.069 & 0.36 \\
20 & 0.052 & 0.17 \\
20 & 0.035 & 0.064 \\
20 & 0.045 \\
20 & 0.031 \\
\hline $\begin{array}{l}\text { The daily dilution rate was equivalent to the growth rate of exponentially } \\
\text { growing cultures at the same temperature }\end{array}$ \\
$\begin{array}{l}\text { Cultures were diluted once a day with low phosphate medium } \\
\S\end{array}$ In all treatments the standard deviation obtained from the four replicates was \\
less than 8\% of the mean value
\end{tabular}


1.67) representing a doubling of growth rate with a $10^{\circ} \mathrm{C}$ increase in temperature (i.e., a $\mathrm{Q}_{10}$ of 2; figure not shown). Decrease in growth rate was associated with an increase in duration of the different cell cycle stages, $G_{1}$ and $G_{2}+M$ showing the most variation relative to the respective increase in generation time and $S$ the stage showing the least (Fig. 1A).

In the phosphate-limited cultures, growth rates decreased as phosphorus supply rates decreased due to reductions in the dilution rate of the cultures (Table 1). Discrepancies between the dilution rates and actual growth rates are a result of variations associated with pipetting the small dilution volumes. Only the empirically determined growth rates were subsequently used for calculations. Similar to the temperature experiment, decreases in growth rate also resulted in a lengthening mostly of $G_{1}$ and $G_{2}+M$ relative to the increase in generation time (Fig. 1B).

In all temperature and phosphate limitation treatments, $G_{1}$ was always the phase with the longest duration. The length of $\mathrm{G}_{1}$ was comparatively longer in the phosphate depletion experiment than in the temperature treatments (Fig. 1A \& B). As an example, at $11^{\circ} \mathrm{C}$ and with a specific growth rate of $0.18, \mathrm{G}_{1}$ was 59 hours, $\mathrm{G}_{2}+\mathrm{M} 28$ hours and $\mathrm{S}$ 4.7 hours long, while at a growth rate of 0.17 under phosphate limitation, $\mathrm{G}_{1}$ was 79 hours, $\mathrm{G}_{2}+\mathrm{M} 15$ hours and $\mathrm{S} 1.8$ hours long (Fig. 1).

Variations in Toxin Content. Toxin content was higher at lower growth rates for both experiments and was higher under phosphate limitation compared to the replete medium conditions (Fig. 2A). In the temperature experiment, and over the range of temperatures studied $\left(20^{\circ} \mathrm{C} \rightarrow 8^{\circ} \mathrm{C}\right)$, the toxin cell quota increased by a factor of 2.1 . Over the range of growth rates studied under phosphate-limiting conditions $(0.36 \rightarrow 0.031)$, the toxin cell quota increased by a factor of 4.8. Toxin content under phosphate limitation was approximately four times as high as in some of the treatments in the temperature experiment 
at the same growth rate. These toxin levels and differences in toxicity between nutrientreplete and phosphate-limited treatments coincide with observations by other authors (Boyer et al., 1987; Anderson et al., 1990b).

Variations in Protein Concentrations. Figure 2B shows the variability in protein concentrations for cells grown at different temperatures. Similar to what was observed for toxin content (Fig. 2A), the levels of protein increased as growth rate decreased. A different pattern was revealed in the phosphate-limited cultures (Fig. 2B). In this case the protein levels decreased at lower growth rates. At rates between 0.2 and 0.4 day $^{-1}$ the levels of protein, $649 \pm 87 \mathrm{pg} \mathrm{cell}^{-1}$, were similar between the two experimental treatments and coincided with values previously reported in the literature (Boyer et al., 1987; Anderson et al., 1990b).

Correlation between Toxin and Protein Contents. The ratios of toxin content to protein per cell were determined for each treatment. In the temperature experiment this ratio was constant at a value of $0.079 \pm 0.006 \mathrm{fmol}$ of toxin per pg of protein (Fig.3). The slope of the linear regression through the data, $\mathrm{a}=0.013$, was not statistically different from zero $(P$ $>0.95$, C.I. 93\%). This ratio was not constant in the phosphate-limited cultures but increased as growth rate decreased $(P<0.005)$ (Fig.3).

Correlation between Toxin Contents and Cell Cycle Phase Durations. Cell cycle phase durations and toxin content were normalized in both experiments against the lowest values of the respective data series. These normalized values showed a clear overlap in the relative changes of $\mathrm{G}_{1}$ duration and toxin content (Fig.4). A linear regression through the normalized data resulted in a slope of $a=0.97\left(R^{2}=0.98\right)$. In both experiments the relative increases in duration of $G_{2}$ and $S$ are different from the concurring relative changes 
Fig. 1. Cell cycle phase durations in Alexandrium fundyense at different growth rates in semi-continuous culture, under nutrient replete or phosphate-limited conditions. $\left(G_{1} \nabla, G_{2}+M \square, S \bullet\right)$. (A) Cells grown in $f / 2$ medium at seven different temperatures ranging from 8 to $20^{\circ} \mathrm{C}$ (see Table 1 for correspondence of $\mu$ with temperature of treatment). (B) Cells grown at different levels of phosphate starvation (see Table 1 for correspondence of $\mu$ with phosphate depletion regimes). 


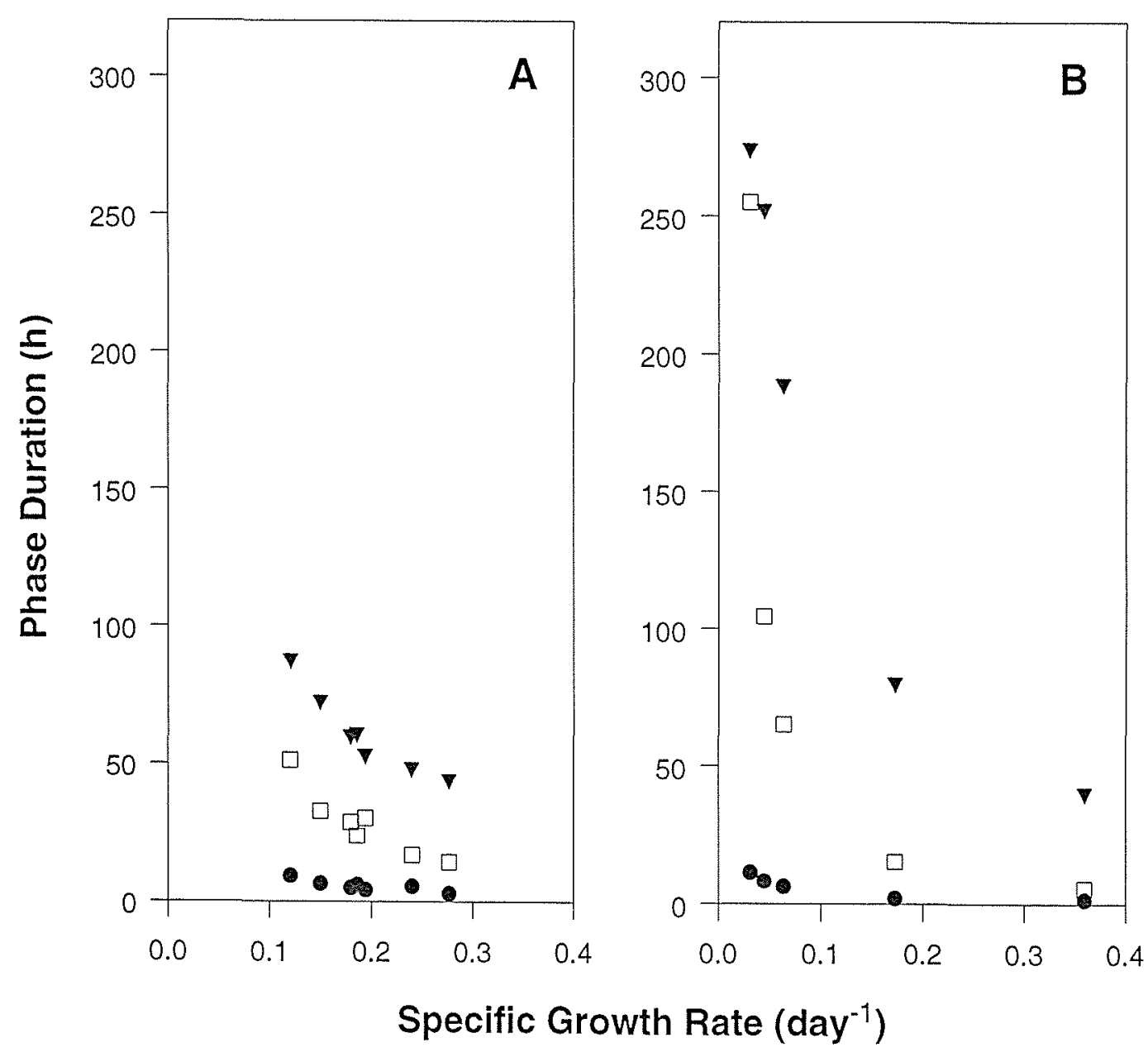


Fig. 2. Changes in (A) total toxin levels and (B) protein concentrations in Alexandrium fundyense grown in semi-continuous culture under temperature-limited conditions in $\mathrm{f} / 2$ medium $(\bullet)$ or under phosphate-limited conditions (O) (Error bars represent SE). 


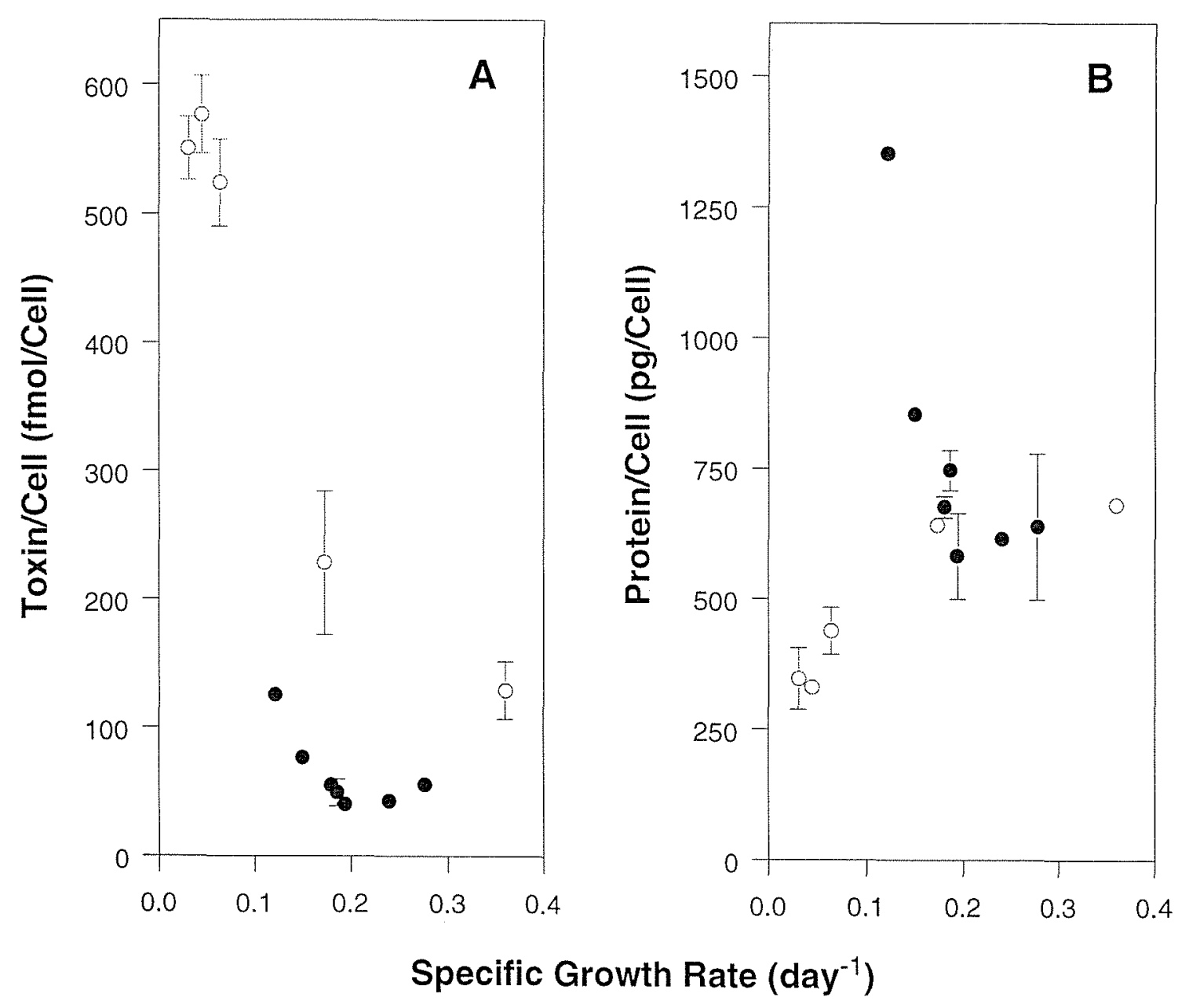


Fig. 3. Ratio of toxin/protein contents in Alexandrium fundyense at different growth rates in semi-continuous culture and under temperature-limited conditions in $\mathrm{f} / 2$ medium $(\bullet)$ or under phosphate-limited conditions $(\mathrm{O})$. 


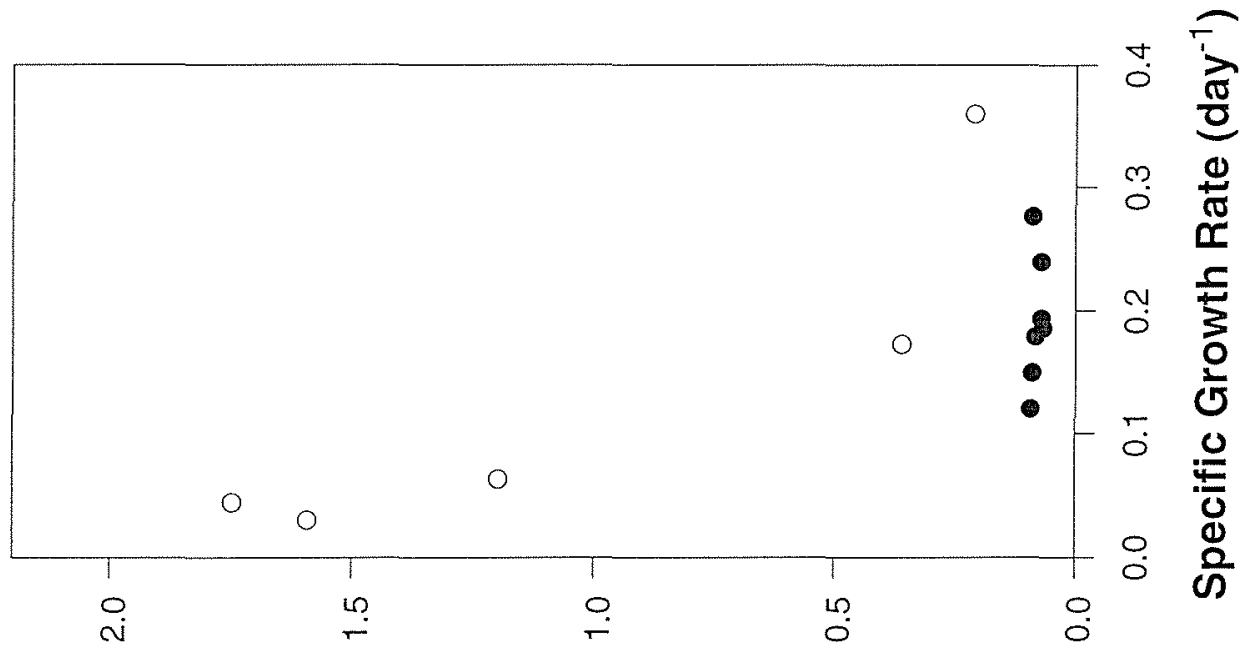

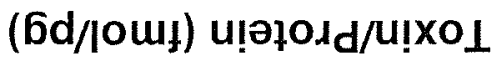


Fig. 4. Relative changes in cell cycle stage durations of $G_{1}(\nabla), G_{2}+M(\square)$ and $S$ (@) against toxin content, for Alexandrium fundyense in semi-continuous culture (dashed line represents 1:1 correlation). Data from experiments under temperature-limited conditions in $\mathrm{f} / 2$ medium and under phosphatelimited conditions are pooled. Data were normalized against the lowest value of the corresponding series (Fig.2). 


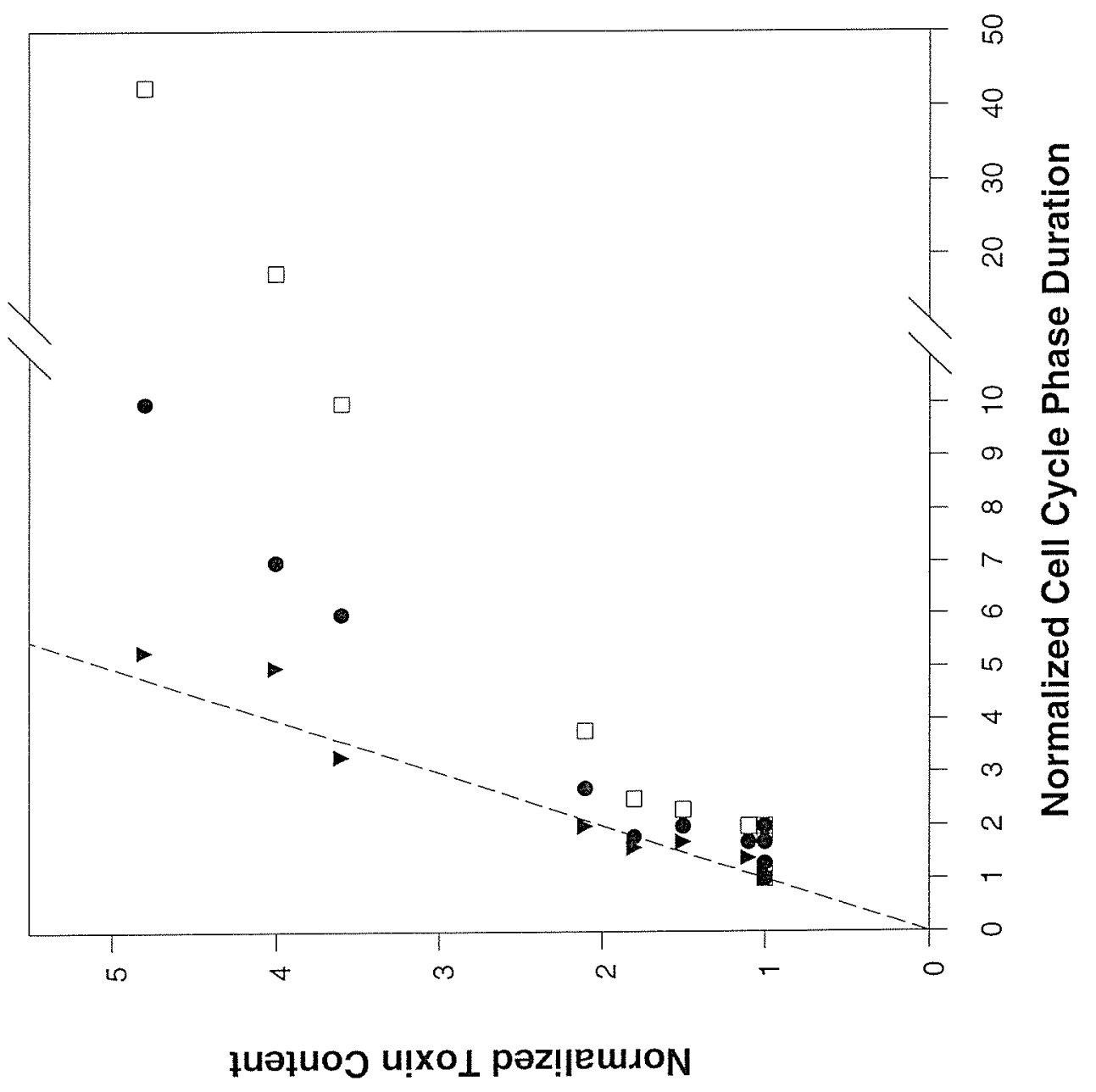


in toxin content. In this case the slopes were $\mathrm{a}=0.46\left(\mathrm{R}^{2}=0.97\right)$ and $\mathrm{a}=0.1\left(\mathrm{R}^{2}=0.88\right)$ respectively.

Toxin Production Rates. Four different net toxin production rates (fmol cell ${ }^{-1}$ hour ${ }^{-1}$ ) were calculated for each of the experimental treatments (Note that production rate is used as an equivalent term for toxin accumulation since we do not know the extent of toxin leakage or catabolism). First, the overall net toxin production rates were determined (Anderson et al., 1990b; Taroncher-Oldenburg et al., 1997). Under steady-state conditions the specific rate of toxin production must equal the specific growth rate of the organism, resulting in a constant toxin concentration per cell. Hence, the net toxin production rate per cell becomes a function of the doubling rate of the organism and the steady state toxin concentration. This can be expressed with the following equations

$$
\mu_{\text {Tox }}=\mu
$$

where $\mu_{\text {Tox }}\left(\mathrm{hr}^{-1}\right)$ is the specific toxin production rate and $\mu$ the specific growth rate $\left(\mathrm{hr}^{-1}\right)$;

$$
\mathrm{R}_{\mathrm{Tox}}=k[\mathrm{Tox}]=(\mu / \ln 2)[\operatorname{Tox}]=\left(\mu_{\mathrm{Tox}} / \ln 2\right)[\mathrm{Tox}]
$$

where $\mathrm{R}_{\text {Tox }}$ (fmol cell-1 $\mathrm{hr}^{-1}$ ) is the net toxin production rate, $k\left(\mathrm{hr}^{-1}\right)$ is the doubling rate and [Tox] (fmol cell-1) represents the toxin cell quota.

We further determined the three cell cycle stage-specific net toxin production rates, i.e., the rates at which toxin would be synthesized if all production occured exclusively during one of the three phases of the cell cycle $\left(\mathrm{G}_{1}, \mathrm{~S}\right.$ or $\left.\mathrm{G}_{2}+\mathrm{M}\right)$. These rates are described by the following equation 


$$
\mathrm{R}_{\mathrm{Tox}}(\mathrm{x})=[\operatorname{Tox}] / T(\mathrm{x})
$$

where $R_{\text {Tox }}(x)$ is the net toxin production rate for each cell cycle stage $\left(x=G_{1}, S\right.$ or $G_{2}+$ M) and $T(\mathrm{x})$ is the duration of each cell cycle stage.

The values of $R_{\text {Tox }}\left(f m o l\right.$ cell $^{-1}$ hour ${ }^{-1} \pm S D$ ) remained constant at a mean value of $0.77 \pm 0.12$ for all of the experimental temperatures (Fig. 5A). The slope of the linear regression through the data, $\mathrm{a}=-0.01$, was not statistically different from zero $(P>0.94$, C.I. $96 \%$ ). A similar pattern was observed for the five phosphate depletion regimes that resulted in a mean value of $3.34 \pm 0.20$ (Fig. 4B). A linear regression through the data also resulted in a slope, $a=0.06$, that was not significantly different from zero $(P>0.89$, C.I. $92 \%$ ). The results for $\mathrm{R}_{\mathrm{Tox}}(\mathrm{x})$ (fmol cell ${ }^{-1}$ hour ${ }^{-1} \pm \mathrm{SD}$ ) for both experiments are plotted in Fig. $5 A$ \& B. $R_{\text {Tox }}\left(G_{1}\right)$ was constant with a mean value of $0.94 \pm 0.21$ in the temperature experiment (Fig. 5A) and $3.56 \pm 0.43$ in the phosphate depletion treatments (Fig. 5B). $\mathrm{R}_{\mathrm{Tox}}(\mathrm{S})$ and $\mathrm{R}_{\mathrm{Tox}}\left(\mathrm{G}_{2}+\mathrm{M}\right)$ showed variations within and between experiments. Linear regressions through these data showed that the slopes of $R_{\text {Tox }}(S)$ and $R_{\text {Tox }}\left(G_{2}+M\right)$ were significantly different from zero in both experiments $(P<0.005$ for all four curves). The slopes of $R_{\text {Tox }}\left(G_{1}\right)$ were $a=-0.01$ for the temperature experiment and $a=0.05$ for the range of phosphate limitations. Both slopes were statistically not different from zero $(P>0.97$, C.I 95\% and $P>0.9$, C.I. $93 \%$ respectively).

Variations in Toxin Composition. The changes in concentrations (fmoles per cell) and relative proportions (mole percent of total toxin) of the eight main saxitoxin derivatives (STX, NEO, GTX I,IV, GTX II,III, C I,II) were determined for the different growth rates in both experiments. Variations in concentration of STX derivatives within each experiment were proportional to the changes in total toxin concentration, resulting in 
Fig. 5. Overall net toxin production rate, $\mathrm{R}_{\mathrm{Tox}}$ (dotted line), and cell cycle stage specific toxin production rates, $R_{\text {Tox }}\left(G_{1}\right)(-\nabla-), R_{\text {Tox }}\left(G_{2}+M\right)(-\square-)$ and $\mathrm{R}_{\mathrm{Tox}}(\mathrm{S})$ (- - ) , for Alexandrium fundyense in semi-continuous culture under (A) temperature-limited conditions in f/2 medium or (B) phosphate-limited conditions (Note scale changes on ordinates). 


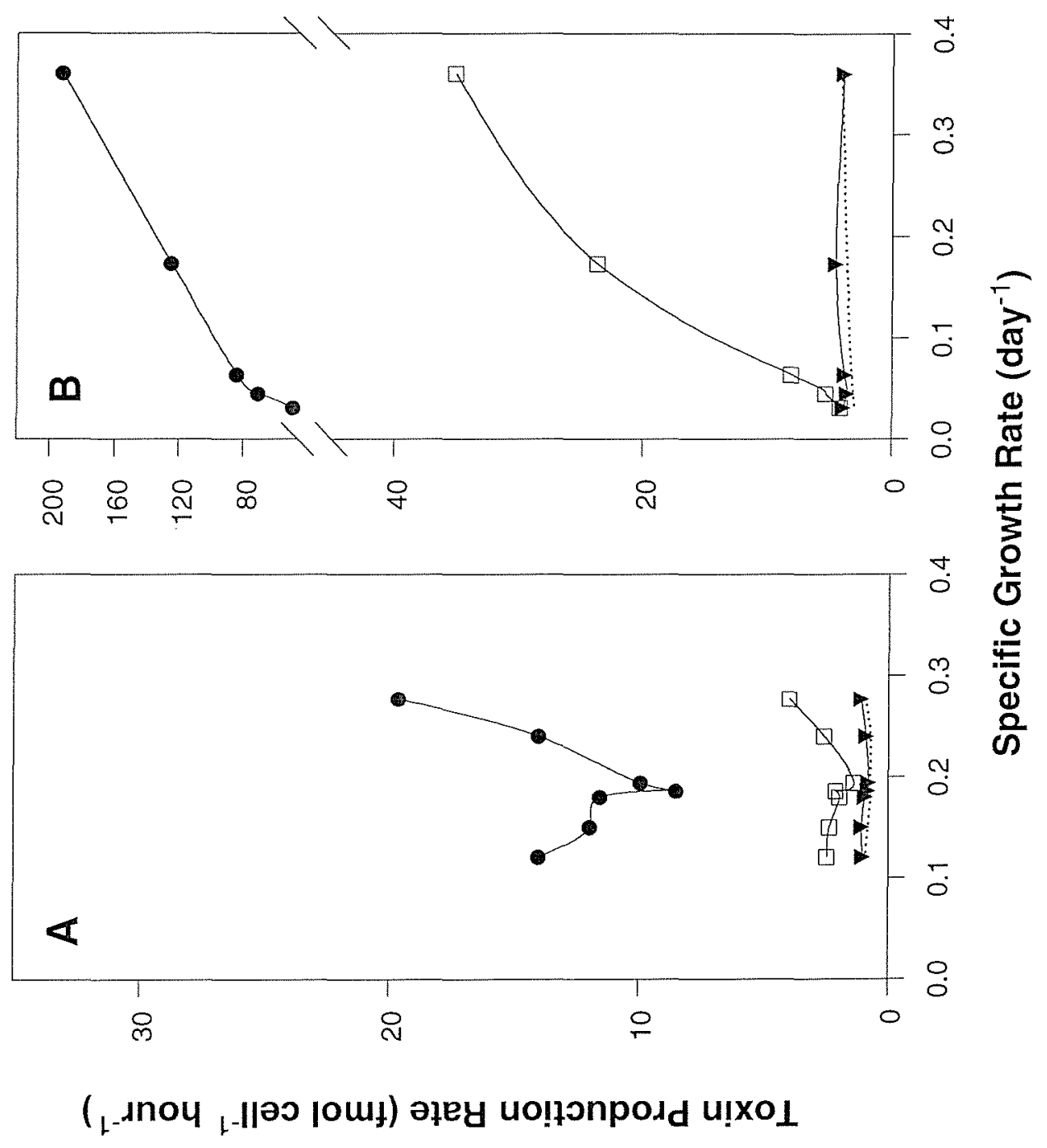


Fig. 6. Toxin composition expressed in fmoles per cell of the different toxin derivatives present in Alexandrium fundyense cells in semi-continuous culture and under temperature limited conditions in $\mathrm{f} / 2$ medium (A) or under phosphate limited conditions (B). ( $\square$ C I,II, $\mathbf{\square T X}$ I,IV, $\triangle$ GTX II,III, $\Delta$ NEO, $\diamond \mathrm{STX})$. 


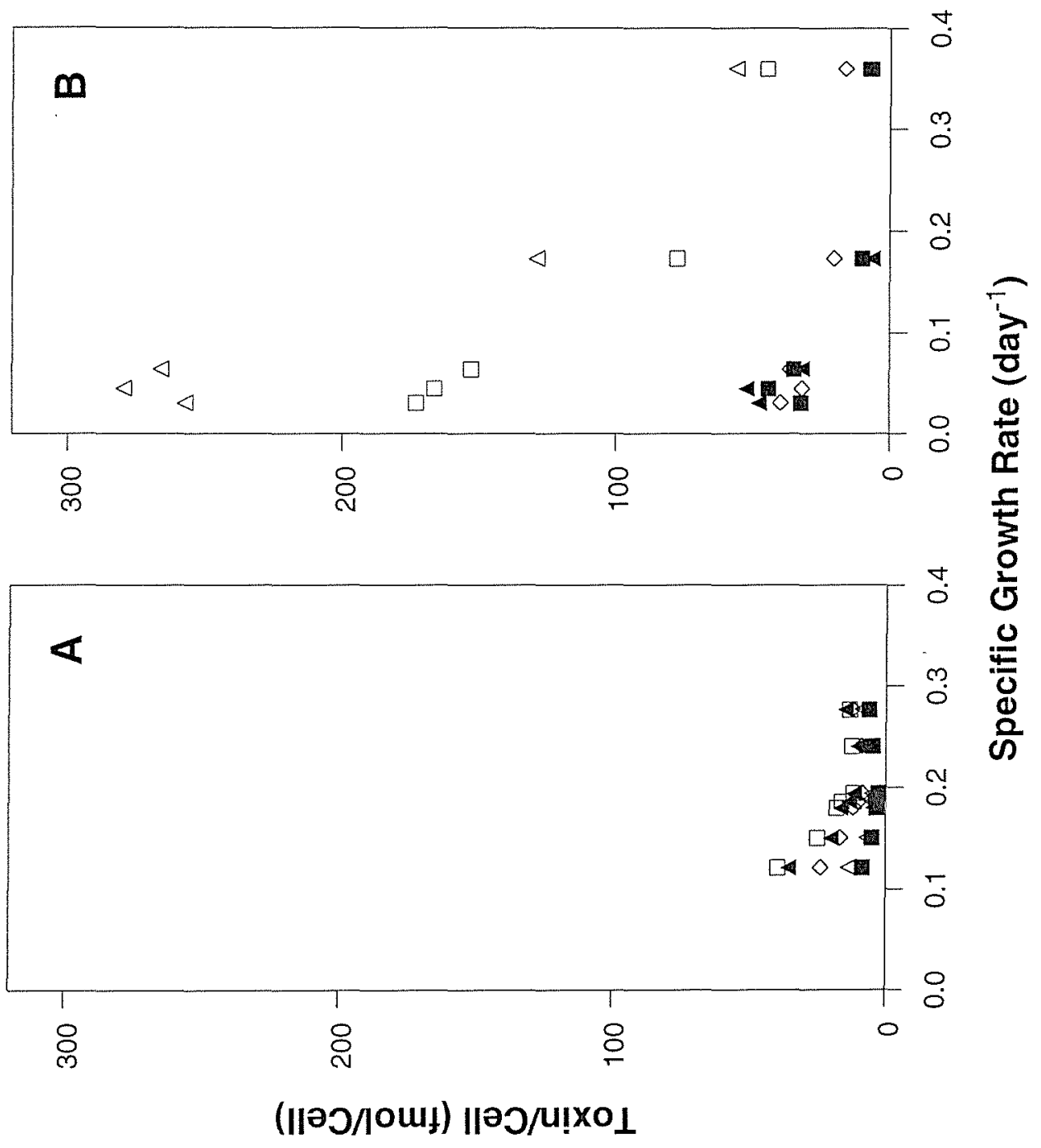


Fig. 7. Toxin composition expressed in mole per cent of total toxin present in Alexandrium fundyense cells in semi-continuous culture and under temperature-limited conditions in $\mathrm{f} / 2$ medium (四) or under phosphate-limited conditions $(\square)$. The relative proportions of the different toxins fall within three distinct groups by either (a) remaining constant, (b) increasing or (c) decreasing under phosphate limitation (Error bars represent SD; $\mathrm{n}=7$ for the temperature experiment, $\mathrm{n}=5$ for the phosphate treatments). 


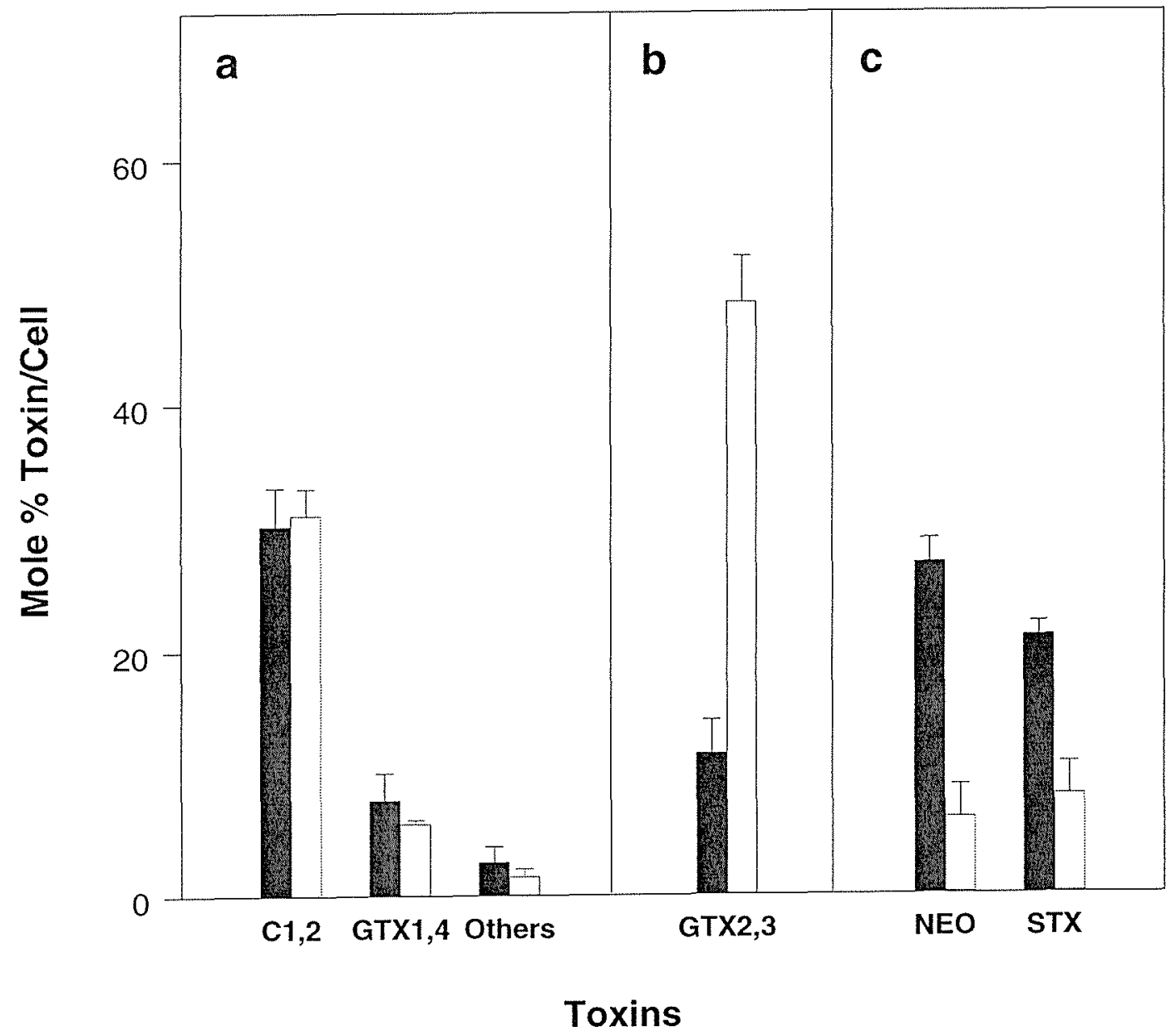


constant relative proportions of the toxins for each of the two experiments (Fig. 5). Differences were only observed in the absolute concentrations and mole $\%$ of the different derivatives between treatments. The concentrations of C I,II and GTX II,III were higher by at least an order of magnitude in cells grown under phosphate starvation compared to cells at similar growth rates in replete medium (Fig. 6). At similar growth rates, no differences in concentration of the other toxins were observed between both experiments (Fig. 6). Analysis of the relative proportions provided a different picture. The percentages of C I,II, GTX I,IV and the traces of other derivatives (Others, Fig. 7) did not vary significantly. The relative proportions of GTX II,III increased significantly under phosphate stress $(12 \% \pm 3 \rightarrow 48 \% \pm 4)$ while NEO and STX decreased from $27 \% \pm 2$ and $21 \% \pm 1$ in the temperature experiment to $6 \% \pm 3$ and $8 \% \pm 2$ respectively under phosphate limitation (Fig. 7).

\section{DISCUSSION}

In the past, toxin production in Alexandrium fundyense has been correlated to several environmental factors including nutrient availability, salinity and temperature (Proctor et al., 1975; White, 1978; Hall, 1982; Boyer et al., 1987; Ogata et al., 1987; Anderson et al., 1990b; Matsuda et al., 1996). Only recently has the correlation of toxin production with a specific physiological process, the cell cycle, been described (Taroncher-Oldenburg et al., 1997). Those studies showed that in synchronized batch cultures STX biosynthesis is turned on only during the $G_{1}$ phase of the cell cycle. In this manuscript we describe a series of independent experiments showing that toxin content is directly correlated to the length of the cell cycle, and more precisely, to the duration of the $G_{1}$ phase of the cell cycle. Semi continuous cultures of Alexandrium fundyense were utilized, as they allowed 
the effects of growth limitation on toxin production dynamics to be analyzed while the extracellular conditions to which the cells had adapted remained stable. In continuous cultures, as well as semi-continuous cultures, the growth rate of an organism is determined by the rate of supply of the limiting nutrient (Monod, 1950; Fogg, 1965).

In one case, we examined the extent to which temperature-induced changes in growth affected toxin production and its linkage to cell cycle events under nutrient-replete conditions. In contrast, phosphate-limited treatments were established to study the effects of nutrient-limited growth on cell proliferation, cell cycle dynamics and toxin production at constant temperature. Phosphate limitation is the only known instance, besides low temperature, in which saxitoxin biosynthesis is enhanced compared to non-limiting conditions (Hall, 1982; Boyer et al., 1987; Anderson, 1990).

The influence of phosphate availability and temperature on toxin and protein production together with cell cycle dynamics and their relationships are discussed below.

\section{The cell cycle}

Over the range of growth rates studied, we observed differing effects of temperature limitation and phosphate starvation on the lengths of the $G_{1}$ and $G_{2}$ phases of the cell cycle. As was observed for the dinoflagellate Amphidinium carterii over a range of decreasing temperatures (Olson et al., 1986), the length of both $G_{1}$ and $G_{2}$ increased with decreasing growth rate in A. fundyense (Fig. 1A). A similar pattern was observed under phosphate limitation. In this case, the length of $G_{1}$ was greater and the $G_{2}$ phase was shorter at all growth rates compared to temperature-limited growth (Fig. 1A \& B). Similar patterns of proportional or general expansion of all cell cycle phases under growth limiting conditions have been observed in mammalian systems and yeast (Rivin and Fangman, 1980; Guiget et al., 1984). The mechanistic explanation is that both energy and nutrient limitation act on processes that control cell cycle progression (e.g., DNA replication and 
protein biosynthesis). Thus, temperature limitation causes a general decrease in enzyme activity, resulting in lower growth rates and, in the case of $A$. fundyense, a nonproportional expansion of the different cell cycle stages.

Under phosphate limitation we observed not only a longer duration of the $\mathrm{G}_{1}$ phase, but also a disproportional expansion of the different phases. The most plausible explanation for these patterns is that phosphate is an essential building block of DNA and hence is a limiting factor for cell cycle progression when present at low concentrations. This suggests that the mechanism controlling cell cycle length under phosphate limiting conditions is a delay of the transition from $\mathrm{G}_{1}$ to the $\mathrm{S}$ phase as the cell needs additional time to accumulate enough phosphate to ensure a successful DNA replication process (Pardee et al., 1978). At lower growth rates induced by more severe phosphate limitation, a second mechanism might become operative. Phosphate is not only an essential element for DNA synthesis, but also is a necessary component of energy transfer, via ATP and related compounds, and is critical to the regulation of protein activity by means of enzyme phosphorylation. At extremely low phosphate concentrations, protein metabolism in preparation for mitosis would be restricted, lengthening $\mathrm{G}_{2}$. Low protein levels at slow growth rates corroborate this interpretation (Fig. 2B). Temperature limitation and phosphate limitation thus affect the cell cycle dynamics in different ways by modulating separate regulatory machineries.

\section{Toxin production and nitrogen pools}

Saxitoxin biosynthesis is dependent on the availability of the amino acid arginine (Arg), its main building block (Shimizu, 1993). Arg is one of the principal constituents of proteins and its metabolism is regulated by temperature and nutrient levels, among other factors, especially nitrogen and phosphate (Meister, 1965). Similarly, STX biosynthesis is dependent on factors such as the nitrogen status of the cells and phosphate availability in 
the medium (Hall, 1982; Boyer et al., 1987; Anderson et al., 1990b; Matsuda et al., 1996). It thus became of interest to look at the correlation between toxin levels and protein accumulation under the different experimental treatments in this study. If toxin and protein production were directly correlated, the ratio of the two components would remain constant under all physiological conditions. We saw such a pattern in the temperature experiment, but not with phosphate limitation, where toxin concentrations became progressively uncoupled from protein concentrations in the cell as the limitation increased (Fig. 3). This ratio distribution suggests selective maintenance of enzymes of toxin biosynthesis at low phosphate concentrations. It can thus be hypothesized, that toxin production is advantageous to Alexandrium as it becomes progressively phosphate-limited.

Previous work has shown that during exponential growth of Alexandrium, pools of Arg do not show any significant differences between phosphate-limited and nutrient-replete cultures (Anderson et al., 1990b). One can surmise that protein and toxin production could be inversely related as a result of protein catabolism and subsequent channeling of Arg through the general Arg pool into STX anabolism. Such a scenario would be supported by the fact that cellular levels of Arg as well as those of other amino acids are under tight control in order to preclude high accumulations detrimental to the cell's physiology (Meister, 1965). However, analysis of the variations in toxin, protein and Arg content at low temperatures reveals a direct correlation between these factors (Anderson et al., 1990b)(Fig. 3), suggesting that the regulatory pathway of STX biosynthesis does not represent a straight recycling of protein-derived Arg into an alternative storage compound, the toxin. Accumulations of protein and STX at low temperatures in this study show the same direct proportionality (Figs. 2A \& B). We conclude that toxin production is not a direct response to a cell's need to balance its nitrogen pools, but the result of a specific pathway integrated in the general nitrogen metabolism of the cell. 


\section{Toxin production and the cell cycle}

Our previous work with synchronized cultures in nutrient-replete medium has shown that STX biosynthesis is turned on during the $\mathrm{G}_{1}$ phase of the cell cycle (TaroncherOldenburg et al., 1997). The main hypothesis we wanted to test with the experiments reported here was whether toxin production and the levels of toxin accumulation were related to one specific cell cycle stage or another under growth limiting conditions. We first set out to determine if levels of STX accumulation, duration of the different cell cycle stages and the deduced toxin accumulation rates for each stage were correlated. We first compared the relative increases in toxin content and cell cycle phase duration for both experiments (Fig. 4A \& B). A clear overlap was observed between the trends and values of relative durations of $\mathrm{G}_{1}$ and the normalized toxin concentrations. These results clearly indicated that toxin production was related to the length of the $\mathrm{G}_{1}$ cell cycle phase. We then went on to determine the cell cycle stage-specific, as well as overall net toxin production rates. A comparison of these parameters showed similar patterns and values for the net and the $\mathrm{G}_{1}$-specific production rates (Fig. 5A \& B). The other two cell cyclespecific rates $\left(G_{2}+M\right.$ and $\left.S\right)$ showed not only a high degree of uncoupling from the overall rates, but their trends also contradicted basic concepts in metabolic regulation. Typically, the end product of a biosynthetic pathway accumulates as a function of enzymatic rates and the length of the time interval during which synthesis occurs. The two extreme cases result in two different scenarios. In the first case, high product concentrations are derived from increases in production rates as a result of biochemical induction of the responsible enzymes. Alternatively, enzymatic rates can remain constant and accumulation of the end product be the consequence of longer periods of biosynthetic activity. This appears to be the case with STX production, as shown by our results (Fig. 5). In both the temperature treatments and the phosphate limitation experiments, toxin production rates remained constant for a range of conditions, implying that the variations in 
toxin content observed (Fig. 2A) were a result of increasing periods of biosynthetic activity. This increase in the length of the toxin production was directly proportional to the changes in duration of the $\mathrm{G}_{1}$ phase of the cell cycle.

The $G_{2}$ and $S$ specific toxin production rates fall into a third category in which an increase in metabolite concentration would be related to an actual decrease in production rates. Such dynamics are to be expected only in the case of a storage product where regulation of biosynthesis is not coupled to metabolite accumulation. One of the possible roles postulated in the past for saxitoxin is as a storage compound for nitrogen (Loeblich, 1984; Boyer et al., 1987; Anderson et al., 1990b). Our data show a coincidence of decreasing protein concentrations with an increase in toxin levels under phosphate limitation (Fig. 2), which would support such a hypothesis, considering that nitrogen was not a limiting factor in those cultures and protein anabolism was probably compromised by the lack of phosphate. However, work by other authors showing no evidence for reallocation of toxin-nitrogen into protein-nitrogen (Hall, 1982; Boyer et al., 1985; Usup, 1995; Flynn et al., 1996), together with our observation of a parallel increase of toxin content and protein levels under the different temperature limitation regimes (Fig. 2A \& B), contradicts such a theory.

\section{Toxin production and phosphate availability}

The role of phosphate in a cell's metabolism is a complex one. The physiological changes we observe under different phosphate starvation regimes are the result of the cumulative effects of phosphate limitation on the entire range of physiological processes in the cell. We observed that both the net and the $\mathrm{G}_{1}$-specific toxin production rates increased by a factor of approximately four in all phosphate-limited regimes compared to the nutrient replete ones over the same range of growth rates (Fig. 5A \& B). This confirmed previous toxin data comparisons for phosphate-limited cultures of Alexandrium where toxin levels 
were consistently higher, also by a factor of four (Boyer et al., 1987; Anderson et al., 1990b). This enhancement of toxin production suggests that phosphate starvation is not acting directly on the biosynthetic pathway but rather increases the rate of substrate supply via down-regulation of other cellular processes (Anderson et al., 1990b). Moreover, the rate of toxin production remains at a constant level throughout the range of phosphate limitation regimes (Fig. 5B). This suggests that the rate of approx. $3.3 \mathrm{fmol} \mathrm{cell}^{-1}$ hour $^{-1}$ is the maximum rate of toxin production under phosphate stress for Alexandrium fundyense.

It is of interest that phosphate deprivation does not limit toxin production, i.e., no reduction in the toxin production rate is observed (Fig. 5A \& B), which implies that phosphate is not an essential cofactor or substrate in saxitoxin biosynthesis. This is further corroborated by the observation that toxin production is uncoupled from protein accumulation under phosphate starvation (Fig. 3). Protein metabolism is dependent on phosphate availability. If STX biosynthesis were phosphate dependent we should observe a similar pattern of variation as the one recorded for protein metabolism. Instead, opposite trends were followed (Fig. 2B).

We conclude that STX biosynthesis is not directly regulated by phosphate, but is indirectly modulated by the effects of phosphate starvation on other cellular processes, such as protein and amino acid metabolism.

\section{Toxin production rate and growth rate}

The results reported here show that net toxin production rate is independent of growth rate under the conditions studied. Net toxin production rates had been previously determined under phosphate limitation in A. fundyense (Anderson, 1990). The average toxin production rate was of approximately $75 \mathrm{fmol} \mathrm{cell}^{-1}$ day $^{-1}\left(=3.12 \mathrm{fmol} \mathrm{cell}^{-1}\right.$ hour $\left.^{-1}\right)$. This value coincides with our value of $3.34 \mathrm{fmol} \mathrm{cell}^{-1}$ hour ${ }^{-1}$. In that instance the toxin 
production rates were suggested to be correlated to growth rate based on their increase at faster growth rates. The discrepancy between those data and the results reported here may lie in the high variability seen in the first case. This is further substantiated by the fact that we observed constant toxin production rates in nutrient-replete cultures and under varying temperatures. Toxin production rates have also been shown to be constant over a range of nitrogen limiting conditions (Anderson et al., 1990b). These data suggest that once a specific limitation threshold is reached, toxin production rates are not affected by further limitation. This has important implications regarding the production of STX as it suggests possible regulatory mechanisms of the biosynthetic pathway. A more precise biochemical interpretation of the data is not possible at this point because none of the enzymes involved in the pathway has been isolated yet. A concerted effort in determining the exact sequence of intermediates and the nature of the enzymes responsible for their processing is necessary in order to overcome this last hurdle of understanding the regulatory mechanisms involved in the biosynthesis of STX.

\section{Toxin composition}

Toxin composition in Alexandrium had long been considered a stable feature of the different species or strains throughout a broad range of physico-chemical conditions (Hall, 1982; Boyer et al., 1987; Ogata et al., 1987) and therefore used as a chemotaxonomic character (Cembella et al., 1987). Only more recently have changes in toxin composition over the life cycle or under varying physiological conditions been documented (Boczar et al., 1988; Anderson, 1990; MacIntyre et al., 1997). Our results add one more example in which a significant change in toxin composition was observed when Alexandrium was subjected to phosphate-limited conditions and grown in semi-continuous culture in nutrient

replete medium (Fig. 6). The most significant changes occured at the level of absolute accumulation of the carbamate derivatives GTX II,III and the sulfocarbamoylated pair C 
I,II (Fig. 6). No significant differences were observed for the total concentrations of the two other carbamate derivatives, GTX I,IV, NEO or STX (Fig. 6). Transformations among STX derivatives, in particular 11- $\alpha-\beta-O$-sulfatation of STX and $16-N$-sulfatation of the resulting pair GTX II,III are enhanced by phosphate starvation, as previously shown by Anderson et al. (1990a). In a similar scenario to the one discussed in the context of enhancement of total toxin production under phosphate limiting conditions, the apparent increase in sulfatation activity is most probably the result of an increase in substrate availability for these enzymes, rather than an induction of enzyme activity. The characterization of the two enzymes responsible for these reactions in Gymnodinium catenatum showed that their activities were not dependent on the presence of phosphate (Yoshida et al., 1996). We can further explain the lack of a parallel and significant change in the total concentration of the pair GTX I,IV, via the equivalent transformation of the 1$N$-hydroxy STX derivative series, by the fact that an 11- $\alpha-\beta-O$-sulfatation activity of NEO has not yet been isolated, and that the two sulfatases of $G$. catenatum do not recognize NEO or the pair GTX I,IV as substrates (Yoshida et al., 1996). A plausible explanation for the observed patterns would therefore be the presence of specific $1-N$-hydroxylases or oxidases of the kind observed before in Alexandrium tamarense (Oshima, 1995) that would in turn transform STX and GTX II,III into NEO and GTX I,IV respectively. Such enzymes are always ATP dependent and hence inhibited in the absence of phosphate.

The resulting scheme of transformations is outlined in Figure 8. It is necessary to point out that the arrows follow opposite directions from those we had postulated in previous experiments with synchronous cultures (Taroncher-Oldenburg et al., 1997), but a comparison of both sets of observations after reinterpretation of the toxin accumulation patterns in those synchronous cultures results in convergence. In that instance, we observed first an accumulation of C I,II followed by GTX II,III and STX and finally GTX I,IV and NEO with a slight delay. We interpreted this to be the sequence in which these 
compounds were formed (i.e., that C I,II were the 'parent' compounds). These data can now be reinterpreted in light of our current results as a process during which C I,II accumulates as a result of the rapid transformation of its direct precursor, GTX II,III, until its equilibrium concentration is reached. This then results in the subsequent accumulation of GTX II,III until its concentration reaches a maximum and STX, the precursor of this latter transformation starts building up. The hydroxylases/oxidases involved in the transformation of STX and GTX II,III into NEO and GTX I,IV only start showing higher activities once the sulfatation reactions that are competing for their substrates stabilize, suggesting that the $\mathrm{K}_{\mathrm{m}}$ of the sulfatases is lower than that of the hydroxylases/oxidases.

One last comment addresses the divergent results obtained when toxin composition is analyzed as absolute values of toxin derivative cell quota or as derivative mole percent of total toxin in intraspecific comparisons between sets of toxin data where the total toxin content has varied significantly (Figs. $6 \& 7$ ). In such cases the relative amounts of the different derivatives have to be contrasted with their actual concentrations in order not to distort the real changes in composition occurring in the cells. This is illustrated by our results: In the temperature experiment, all derivatives are loosely grouped at similar levels of concentration, C I,II consistently showing the highest concentration (Fig. 6A). In contrast, under phosphate-limiting conditions GTX II,III are very clearly present at the highest concentration, with C I,II coming second and the rest of the derivatives all clustering at similar concentrations to those observed in the temperature treatments (Fig. 6B). These results indicate a pattern of enhanced accumulation of GTX II,III and C I,II under phosphate limitation. Analysis of these same data by normalizing the concentration of each derivative to total toxin provides a different picture (Fig. 7). A clear change can still be seen for GTX II,III but the proportion of C I,II remains constant. In addition, NEO and STX also show a significant decrease. These differences between analytical approaches reflect the loss of information associated with representing toxin concentrations 
Fig. 8. Suggested scheme of interconversions among the main STX derivatives synthesized by Alexandrium fundyense. The arrows show the most plausible direction for the transformations. $\Theta$ denotes possible inhibition of specific enzyme activity. 


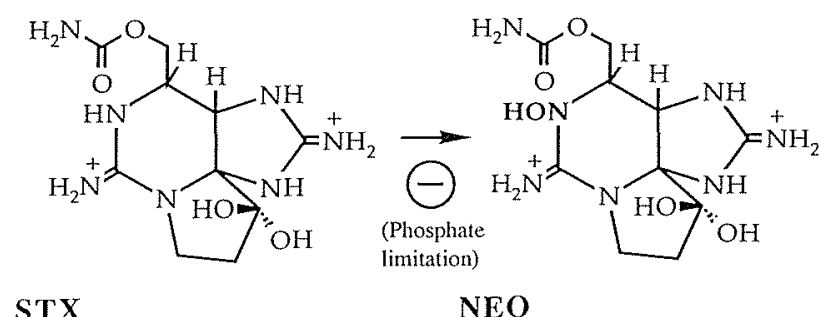

STX
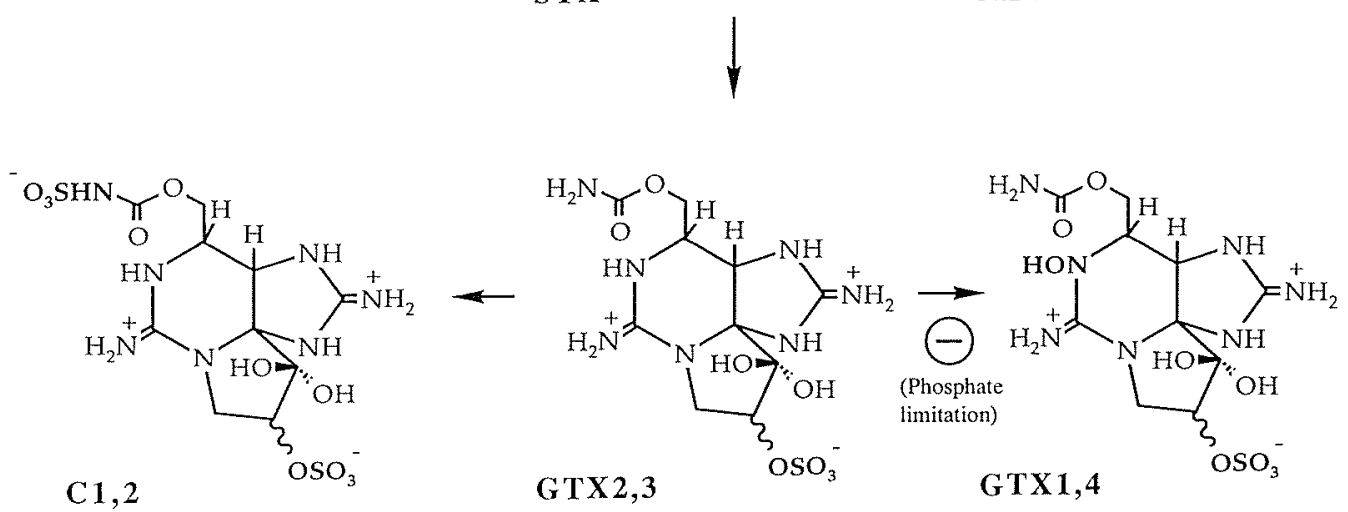
as relative amounts of the total toxin. While not invalidating mole \% representations as a means for comparing different organisms or determining qualitative, and to a certain extent, quantitative variations for one species, our results imply that changes in the physiology of toxin interconversions can only be inferred from the absolute values of the toxin cell quota for each derivative.

Summarizing the toxin composition portion of this study, the patterns of change we observed, together with the fact that within treatments the variation in toxin composition among the different growth rates was minimal, suggest that phosphate starvation affects toxin speciation at the level of hydroxylase/oxidase activities. In an integrated scheme of the STX biosynthetic pathway, interconversions among the toxins would be determined in part by the presence or absence of the appropriate enzymes, but net total toxin production would be the result of the accumulation of only one precursor or parent compound. This precursor could be one of the toxins or another unknown compound (Shimizu, 1993). Further efforts to identify and isolate intermediate compounds are necessary in order to determine the exact sequence of the biosynthetic pathway. 


\section{REFERENCES}

Anderson, D. M. (1989) Toxic algal blooms and red tides: A global perspective. In Red tides: Biology, Environmental science, and toxicology, ed. Okaichi, Anderson, D. M. and Nemoto, pp. 11-16. Elsevier Science Publishing, New York.

Anderson, D. M. (1990) Toxin variability in Alexandrium species. In Toxic marine phytoplankton, ed. E. Graneli, Sundstrom, B., Edler, L. and Anderson, D. M., pp. 41-51. Elsevier,

Anderson, D. M., Kulis, D. M., Doucette, G. J., Gallagher, J. C. and Balech, E. (1994) Biogeography of toxic dinoflagellates in the genus Alxandrium from the northeastern United States and Canada. Mar. Biol. 120, 467-478.

Anderson, D. M., Kulis, D. M., Sullivan, J. J. and Hall, S. (1990a) Toxin composition variations in one isolate of the dinoflagellate Alexandrium fundyense. Toxicon $\mathbf{2 8}$, 885-893.

Anderson, D. M., Kulis, D. M., Sullivan, J. J., Hall, S. and Lee, C. (1990b) Dynamics and physiology of saxitoxin production by the dinoflagellates Alexandrium spp. Mar. Biol. 104, 511-524.

Binder, B. J. and Anderson, D. M. (1990) Biochemical composition and metabolic activity of Scrippsiella trochoidea (dinophyceae) resting cysts. J. Phycol. 26, 289-298.

Boczar, B. A., Beitler, M. A., Liston, J., Sullivan, J. J. and Cattolico, R. A. (1988) Paralytic shellfish toxins in Protogonyaulax tamarensis and Protogonyaulax catenella in axenic culture. Plant Physiol. 88, 1285-1290.

Boyer, G. L., Sullivan, J. J., Andersen, R. J., Harrison, P. J. and Taylor, F. J. R. (1987) Effects of nutrient limitation on toxin production and composition in the marine dinoflagellate Protogonyaulax tamarensis. Mar. Biol. 96, 123-128.

Boyer, G. L., Sullivan, J. J., Harrison, P. J. and Taylor, F. J. R. (1985) Toxin production in three isolates of Protogonyaulax sp. In Toxic Dinoflagellates, ed. D. M. Anderson, White, A. W. and Baden, D. G., pp. 281-286. Elsevier, New York, Amsterdam, Oxford.

Cembella, A. D., Sullivan, J. J., Boyer, G. L., Taylor, F. J. R. and Andersen, R. J. (1987) Variation in paralytic shellfish toxin composition within the Protogonyaulax tamarensis/catenella species complex: red tide dinoflagellates. Biochem. System. Ecol. 15, 171-186.

Cetta, C. M. and Anderson, D. M. (1990) Cell cycle studies of the dinoflagellate Gonyaulax polyedra Stein and Gyrodinium uncatenum Hulburt during asexual and sexual reproduction. J. Exp. Mar. Biol. Ecol. 135, 69-84. 
Flynn, K., Franco, J. M., Fernández, P., Reguera, B., Zapata, M., Wood, G. and Flynn, K. J. (1994) Changes in toxin content, biomass and pigments of the dinoflagellate Alexandrium minutum during nitrogen refeeding and growth into nitrogen or phosphorus stress. Mar. Ecol. Prog. Ser. 111, 99-109.

Flynn, K. J., Flynn, K., John, E. H., Reguera, B., Reyero, M. I. and Franco, J. M. (1996) Changes in toxins, intracellular and dissolved free amino acids of the toxic dinflagellate Gymnodinium catenatum in response to changes in inorganic nutrients and salinity. J. Plankton Res. 18, 2093-2111.

Fogg, G. E. (1965) The characteristics of algal growth in cultures of limited volume. In Algal Cultures and Phytoplankton Ecology, ed. G. E. Fogg, pp. 126. The University of Wisconsin Press, Madison, WI.

Forde, B. G. and John, P. C. (1974) Transcription, translation and maturation of succinate dehydrogenase during the cell cycle. Nature 252, 410-412.

Guiget, M., Kupiec, J. J. and Valleron, A. J. (1984) A systematic study of the variability of cell cycle phase durations in experimental mammalian systems. In Cell Cycle Clocks, ed. L. N. Edmunds, pp. 97-111. Dekker, M., New York.

Guillard, R. R. L. and Ryther, J. H. (1962) Studies of marine phytoplanktonic diatoms. Cyclotella nana Hustedt and Detonula confervacea (Cleve) Gran. Can. J. Microbiol. 8, 229-239.

Hall, S. (1982) Toxins and toxicity of Protogonyaulax from the northeast Pacific, Ph.D., Univ. of Alaska.

Jitts, H. R., McAllister, C. D., Stephens, K. and Strickland, J. D. H. (1964) The cell division rates of some marine phytoplankters as a function of light and temperature. $J$. Fish. Res. Board Can. 21, 139-157.

Kates, J. R. and Jones, R. F. (1967) Periodic increases in enzyme activity in synchronized cultures of Chlamydomonas reinhardii. Biochim. Biophys. Acta 145, 153-158.

Loeblich, A. R. I. (1984) Dinoflagellate physiology and biochemistry. In Dinoflagellates, ed. D. L. Spector, pp. 299-342. Academic Press, Orlando.

MacIntyre, J. G., Cullen, J. J. and Cembella, A. D. (1997) Vertical migration, nutrition and toxicity in the dinoflagellate Alexandrium tamarense. Mar. Ecol. Prog. Ser. 148, 201-216.

Matsuda, A., Nishijima, T. and Fukai, K. (1996) Effects of nitrogen deficiency on the PSP production by Alexandrium catenella under axenic cultures. In Harmful and Toxic Algal Blooms, ed. T. Yasumoto, Oshima, Y. and Fukuyo, Y., pp. 305-308. UNESCO, Paris.

Meister, A. (1965) Intermediary metabolism of the amino acids:Arginine, Ornithine and Citrulline; Urea synthesis. In Biochemistry of the amino acids, ed. A. Meister, pp. 685-706. Academic Press, New York. 
Mitchison, J. M. (1969) Enzyme synthesis in synchronous cultures. Science 165, 657663.

Mitchison, J. M., Creanor, J. and Novak, B. (1991) Coordination of growth and division during the cell cycle of fission yeast. Cold Spring Harb. Symp. Quant. Biol. 56, The Cell cycle, 557-565.

Monod, J. (1950) La technique de culture continu; théorie et applications. Ann. inst. Pasteur 79, 390-401.

Ogata, T., Kodama, M. and Ishimaru, T. (1987) Toxin production in the dinoflagellate Protogonyaulax tamarensis. Toxicon 25, 923-928.

Olson, R. J. and Chisholm, S. W. (1986) Effects of light and nitrogen limitation on the cell cycle of the dinoflagellate Amphidinium carteri. J. Plankton Res. 8, 785-793.

Olson, R. O., Vaulot, D. and Chisholm, S. W. (1986) Effects of environmental stresses on the cell cycle of two marine phytoplankton species. Plant Physiol. 80, 918-925.

Oshima, Y. (1995) Chemical and enzymatic transformation of paralytic shellfish toxins in marine organisms. In Harmful Marine Algal Blooms, ed. P. Lassus, Arzul, G., Erard, E., Gentien, P. and Marcaillou, C., pp. 475-480. Lavoisier, Paris.

Oshima, Y., Sugino, K. and Yasumoto, T. (1989) Latest advances in HPLC analysis of paralytic shellfish toxins Seventh International IUPAC Symposium on Mycotoxins and Phycotoxins 319-326.

Pardee, A. B., Dubron, R., Hamlin, J. L. and Klevtzien, R. F. (1978) Animal cell cycle. Ann. Rev. Biochem. 47, 715-750.

Proctor, N. H., Chan, S. L. and Trevor, A. J. (1975) Production of saxitoxin by cultures of Gonyaulax catenella. Toxicon 13, 1-9.

Rivin, C. J. and Fangman, W. L. (1980) Cell cycle phase expansion in N-limited cultures of Saccharomyces cerevisiae. J. Cell Biol. 85, 96-107.

Shimizu, Y. (1993) Microalgal metabolites. Chem. Rev. 93, 1685-1698.

Slater, M. L., Sharrow, S. O. and Gart, J. J. (1977) Cell cycle of Saccharomyces cerevisiae in populations growing at different rates. Proc. Natl. Acad. Sci. (USA) 74, 3850-3854.

Sommer, H., Whedon, W. F., Kofoid, C. A. and Stohler, R. (1937) Relation of paralytic shellfish poison to certain plankton organisms of the genus Gonyaulax. Am. Med. Assoc. Arch. Pathol. 24, 537-559.

Taroncher-Oldenburg, G., Kulis, D. M. and Anderson, D. M. (1997) Toxin variability during the cell cycle of the dinoflagellate Alexandrium fundyense. $L \& O 42,1178-88$.

Usup, G. (1995) The physiology and toxicity of the red tide dinoflagellate Pyrodinium bahamense var. compressum, Ph.D., Boston University. 
Vassef, A. A., Flora, J. B., Weeks, J. G., bibbs, B. S. and Schmidt, R. R. (1973) The effects of enzyme synthesis and stability and of deoxyribonucleic acid replication on the cellular levels of aspartate transcarbamylase during the cell cycle of the eucaryote Chlorella. J. Biol. Chem. 248, 1976-1985.

Vaulot, D. (1985) Cell cycle controls in marine phytoplankton, Ph.D., Woods Hole Oceanographic Institution/Massachusetts Institute of Technology.

Watras, C. J., Chisholm, S. W. and Anderson, D. M. (1982) Regulation of growth in an estuarine clone of Gonyaulax tamarensis Lebour: Salinity-dependent temperature responses. J. Exp. Mar. Biol. Ecol. 62, 25-37.

White, A. W. (1978) Salinity effects on growth and toxin content of Gonyaulax excavata, a marine dinoflagellate causing paralytic shellfish poisoning. $J$. Phycol. 14, 475-479.

Yamaguchi, M. and Honjo, T. (1989) Effects of temperature, salinity and irradiance on the growth of the noxious red tide flagellate Gymnodynium nagasakiense. Nippon Suisan Gakk. 55, 2029-2036.

Yoshida, T., Sako, Y., Uchida, A., Ishida, Y., Arakawa, O. and Noguchi, T. (1996) Purification and properties of paralytic shellfish poisoning toxins sulfotransferase from toxic dinoflagellate Gymnodinium catenatum. In Harmful and Toxic Algal Blooms, ed. T. Yasumoto, Oshima, Y. and Fukuyo, Y., pp. 499-502. UNESCO, Paris. 


\section{CHAPTER III}

Identification and characterization of up- and downregulated genes during saxitoxin biosynthesis in Alexandrium fundyense (Dinophyceae) 


\begin{abstract}
Genes showing a pattern of transcriptional induction or suppresion that coincided with changes in saxitoxin (STX) biosynthesis in the toxic dinoflagellate Alexandrium were identified and characterized. First, differential display (DD) of mRNA was applied to the comparative analysis of different toxic and non-toxic strains of Alexandrium tamarense and $A$. fundyense. The genetic variation was large enough to make it impossible to identify differentially expressed genes over the general variation between DD patterns due to inter-strain dissimilarities. Interspecific variations between $A$. tamarense and closely related strains of $A$. fundyense were equally uninformative. A second approach consisted in DD analysis of cells in different cell cycle stages and while toxin production was turned on or off during synchronized growth of A. fundyense. Three genes were isolated: $S$-adenosylhomocysteine hydrolase (SAHH), methionine aminopeptidase (MAP) and a histone-like protein (HAf). SAHH was downregulated, while MAP and HAf were upregulated during the interval when toxin biosynthesis was occurring. SAHH and MAP showed, respectively, about $90 \%$ and $70 \%$ similarity at the aminoacid level with several eukaryotic and prokaryotic SAHHs and MAPs. The partial MAP sequence also contained three cobalt binding motifs characteristic of MAPs. HAf showed a $60 \%$ similarity at the aminoacid level with two histone-like proteins from the dinoflagellate Crypthecodinium cohnii Biecheler. None of the three genes isolated seemed to specifically relate to STX biosynthesis. One gene, encoding the putative histone-like protein HAf, could be a cell cycle-related gene since it encodes for a protein that is surmised to have DNA structural and regulatory functions. The two other genes, SAHH and MAP, are both involved in regulatory pathways. As an active component in the modulation of one-carbon metabolism and the biosynthesis of $S$-adenosylmethionine, a precursor of STX, SAHH is the enzyme most closely related to STX biosynthesis. This
\end{abstract}


study further documents the potential of applying DD to the identification of genes that are related to physiological processes or cell cycle events in phytoplankton under conditions where small sample volumes represent an experimental constraint. We also show for the first time that pre-translational or transcriptional regulation does indeed occur in dinoflagellates. Previous reports had suggested the possibility that translational mechanisms could be the primary means of circadian regulation in these organisms. We have shown not only the induction or suppression of the three genes described above, but also observed transcriptional or pre-translational regulation of about twenty other genes with varying $\mathrm{DD}$ patterns. 


\section{INTRODUCTION}

Marine dinoflagellates represent a substantial fraction of bloom-forming phytoplankton in coastal areas of the world's oceans (Anderson, 1989). In addition to the formation of red tides, some species of dinoflagellates also produce a range of toxins that are poisonous to higher levels of the food web (Shimizu, 1993). One group of toxins synthesized by these harmful algal bloom organisms causes Paralytic Shellfish Poisoning or PSP. The toxins included in this group are called saxitoxins and are all cyclic perhydropurine compounds differing slightly in toxicity (Hall et al., 1990; Shimizu, 1993). Besides dinoflagellates, other organisms also biosynthesize PSPs, as for example bacteria (Silva and Sousa, 1981; Kodama et al., 1988) and cyanobacteria (Shimizu et al., 1984; Negri et al., 1997).

Much work has been done on the ecology and physiology of STX production in Alexandrium fundyense (Dinophyceae) as well as on determining the basic precursors of this compound. As a result, we now know that saxitoxin is synthesized from one molecule of arginine (Arg), three guanido/ureido groups, derived from Arg as well, an acetate moeity, probably via Acetyl-CoA, and one methyl group donated by $S$-adenosylmethionine. Further studies of the biosynthetic pathway have been hampered by difficulties in manipulating this organism at the biochemical and genetic level. Conventional tools such as mutational analysis or transformation cannot be applied to identify the actual 'toxin genes' because of biological and technical constraints such as lack of information on the number of copies of the 'toxin genes', limitations in culturing dinoflagellates on solid media and the high content of DNA per cell that would make it necessary to screen unrealistic numbers of clones in order to detect one mutant.

Classic mating experiments with toxic and non-toxic strains of Gymnodinium sp. and Alexandrium sp. have revealed that inheritance of toxigenic potential and of toxin 
composition in dinoflagellates follow Mendelian rules (Sako et al., 1992; Oshima et al., 1993; Sako et al., 1995). The non-random segregation patterns observed in the crossings also imply chromosomal localization of the genes involved in toxin biosynthesis and interconversions among derivatives (Oshima, 1995; Sako et al., 1995). A series of studies with synchronized cultures of Alexandrium fundyense has further shown that STX is synthesized during a discrete time period localized in the $\mathrm{G}_{1}$ phase of the cell cycle (Fig. 1) (Taroncher-Oldenburg et al., 1997). The combination of these two factors, nuclear genes and discontinuous toxigenesis, gives rise to the hypothesis that STX biosynthesis could be regulated at the transcriptional level with the genes responsible for toxin production being activated in a cyclic pattern. Furthermore, comparative analysis of cells harvested when toxin production is on or off would allow the identification of genes that are expressed while STX is produced and are therefore potentially related to toxigenesis.

Recent advances in the development of molecular tools aimed at analyzing differences between complex genomes at the level of gene expression show great promise in this regard. One such tool is Differential Display, a genetic approach that allows the analysis of differentially expressed genes in eukaryotes (Liang and Pardee, 1992). This technique has been successfully used to identify developmentally, environmentally or hormonally regulated genes in protozoa, plants, animals and humans (Utans et al., 1994; Abrahamsen et al., 1995; Sharma and Davis, 1995; van der Knaap and Kende, 1995). In this procedure (Fig. 2), the two or more sets of differentially expressed messenger RNAs (mRNAs) to be compared are used as templates to generate the corresponding complementary copy DNAs (cDNAs). Subsequently, the cDNA fragments are amplified by means of the polymerase chain reaction (PCR) using a combination of an mRNA specific oligo(dT) "anchor" primer together with an arbitrary decamer primer in the presence of radioactively labeled dNTPs. After separation in denaturing polyacrylamide 
Figure 1 Saxitoxin biosynthesis and the cell cycle in synchronously growing Alexandrium fundyense. Lines show relative distributions of cells in the different cell cycle stages $\left(\mathrm{G}_{1},-\mathbf{-}-; \mathrm{S},-\bullet-\right.$ and $\left.\mathrm{G}_{2}+\mathrm{M},-\bullet-\right)$. Positive toxin production rates (black bars) are circumscribed to the first eight to ten hours of the duration of the $G_{1}$ cell cycle phase. No toxin production is detected for the remainder of the cell cycle. Arrows denote sampling points for the Differential Display analysis protocol: Two during $G_{1}$, (I) when toxin is accumulated and (II) after it stops, one during the $\mathrm{S}$ phase (III) and a last one during $G_{2}$ (IV). Shaded areas correspond to the dark periods of the $14: 10$ hour light:dark cycle under which $A$. fundyense was synchronized. 


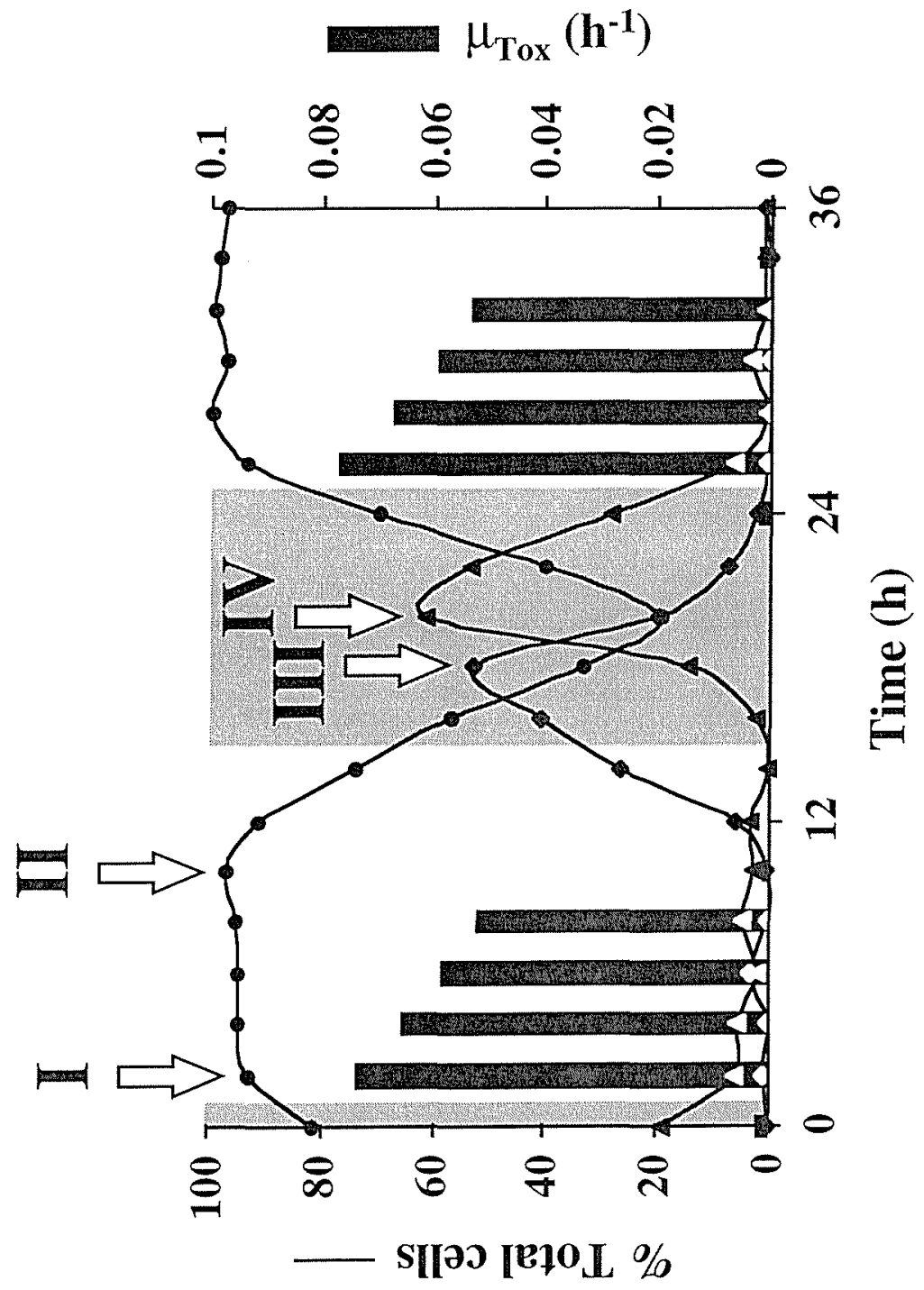


Figure 2 Differential Display. The mRNA components to be compared undergo successive steps of reverse trancription (RT) and amplification through the polymerase chain reaction (PCR) using on mRNA specific 'anchor' primer and one 'random' decamer. This is followed by visualization of the PCR products on a PAGE gel. Differences in expression are identified, extracted and cloned for further analysis. (See materials and methods for details) 
STX biosynthesis OFF
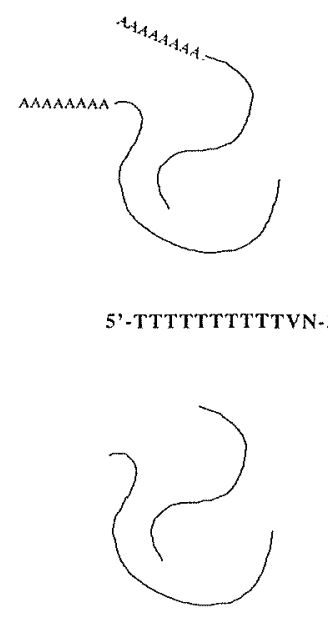

5'-TTtTTTtTT'TVN-3, 5'-NNNNNNNNNN-3'

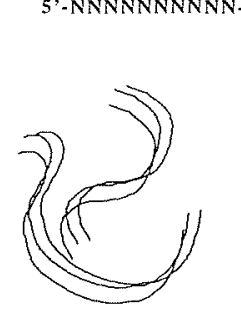

STX biosynthesis ON
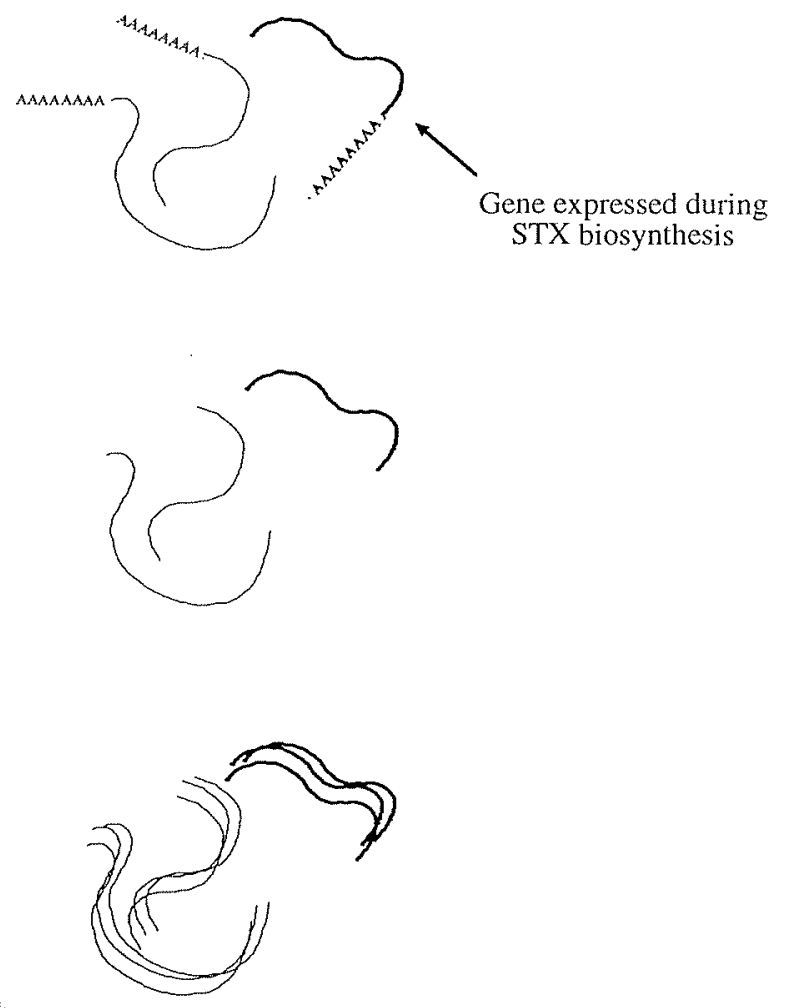
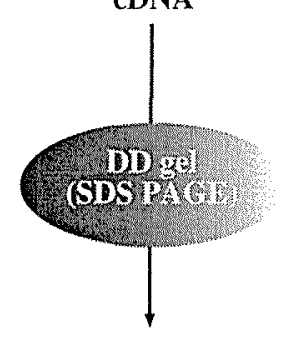

4
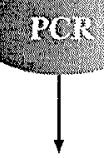

amplified cDNA

autoradiography

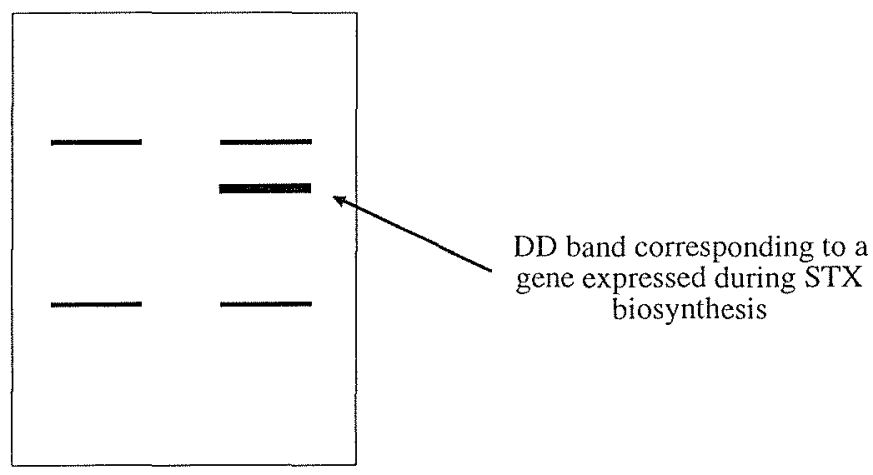


gel electrophoresis, differentially amplified cDNAs are identified by autoradiography. These cDNAs are further cloned and used as probes to screen cDNA libraries of the organism of interest.

The goal of this study was to identify genes for which expression was correlated to toxin production in Alexandrium. Differential Display was used to analyze mRNA expression patterns among cells differing in their toxigenic status. A first approach consisted in comparing phylogenetically closely related toxic and non-toxic strains of $A$. tamarense and A. fundyense. A second approach consisted in the identification of genes for which expression cycles were correlated to the discontinuous pattern of STX biosynthesis in A. fundyense. Synchronously growing cultures of A. fundeyense were harvested several times throughout their cell cycle at times of variable toxigenic status. Several genes were identified and their possible role in STX biosynthesis explored.

\section{MATERIALS AND METHODS}

Organisms. Batch cultures of the non-toxic strains of Alexandrium tamarense PGt183 (Plymouth, UK), Pe1V (Galicia, Spain) and WKS-1 (Tanabe Bay, Japan) and the toxic strains of A. tamarense GtPP03 (Perch Pond, MA), AtSL12 (St. Lawrence estuary, Canada), GtLI21 (Moriches Bay, NY) and A. fundyense GtCA28 (Cape Ann, MA) and Gt7 (Bay of Fundy, Canada) were used in this study. Cultures were maintained at $20^{\circ} \mathrm{C}$ in $\mathrm{f} / 2$ medium (Guillard and Ryther, 1962) modified by addition of $\mathrm{H}_{2} \mathrm{SeO}_{3}\left(10^{-8} \mathrm{M}\right)$ and by reducing the concentration of $\mathrm{CuSO}_{4}$ to $10^{-8} \mathrm{M}$. Vineyard Sound seawater $(0.2 \mu \mathrm{m}$ filtered, $31 \%$ salinity) was used as the medium base. Throughout the experiment, irradiance of ca. $250 \mu \mathrm{E} \mathrm{m}^{-2} \mathrm{~s}^{-1}$ was provided by cool white fluorescent bulbs on a $14: 10 \mathrm{~h}$ light:dark cycle. Cultures were harvested in mid-exponential phase. 
Synchronization of Alexandrium fundyense. Cultures of Alexandrium fundyense GtCA28 (see above for details) were synchronized by a dark induced block/release method (Taroncher-Oldenburg et al., 1997). Low-density (approx. 500 cells/ml), exponentially growing cultures (L:D 14:10h) of Alexandrium fundyense, strain GtCA28, were left in continous darkness for 82 hours and then re-exposed to the original Light:Dark cycle. At the end of the dark period, all the cells had divided once more and were arrested in the $G_{1}$ phase of their cell cycle. Cell size and density were monitored with a Multisizer apparatus (Coulter Counter Ltd., GB) every two hours for a period of two days. Samples for DNA analysis (50,000-100,000 cells) were taken with the same periodicity and preserved in $5 \%$ formaldehyde at $-20^{\circ} \mathrm{C}$. The samples were treated with the DNA-specific stain propidium iodide (PI) $\left(4 \mathrm{~g} \mathrm{ml}^{-1} \mathrm{PI}, 250\right.$ units RNaseA ml-1) and analyzed on a FaxScan Flowcytometer (Becton Dickinson).

RNA Purification. $1-3 \times 10^{6}$ cells were harvested through centrifugation at $4,400 \mathrm{~g}$ for 5 minutes at $4^{\circ} \mathrm{C}$. The pellet was deep-frozen in liquid $\mathrm{N}_{2}$ and then resuspended in $1 \mathrm{~mL}$ of RNA STAT-60 (TEL-TEST "B", Inc., TX). The suspensions were placed in a $\mathrm{N}_{2}$ cell disruption bomb and the cells ruptured in three consecutive cycles of nitrogen decompression at 2,000 psi (Parr Instrument Company, Moline, IL). Homogenates were processed following the manufacturer's protocol (RNA precipitation for 1 hour) with an additional RNA precipitation in the presence of $\mathrm{NaOAc}(\mathrm{pH} 5.2$, final conc. $0.3 \mathrm{M}$ ) and two volumes of ethanol for 1 hour at $-70^{\circ} \mathrm{C}$. RNA was quantified and stored at $-70^{\circ} \mathrm{C}$.

Differential Display. Differential Display (DD) of mRNA was performed as previously described by Liang and Pardee (Liang and Pardee, 1992; Liang et al., 1993). The reverse transcription and PCR were modified as follows. Total RNA $(0.2 \mu \mathrm{g})$ was reverse transcribed with 200 units of M-MLV Reverse transcriptase (Superscript, RNase 
$\mathrm{H}^{-}$, GIBCO-BRL), $40 \mu \mathrm{M}$ dNTPs and $1 \mu \mathrm{M}$ of one of the four different degenerate oligo(dT) primers (NBI, Plymouth, $\mathrm{MN}$ ) $\mathrm{T}_{12} \mathrm{VN}(\mathrm{V}=\mathrm{dA}, \mathrm{dC}$ or $\mathrm{dG}$ ). Control reactions were performed with total RNA in the absence of RTase and with RNAse treated RNA in the presence of RTase. The resulting cDNA was then amplified by PCR with a combination of the respective degenerate oligo(dT) primer and one random decamer primer (OPERON 10-mer kit A, Operon Technologies) and in the presence of $\alpha-\left[{ }^{33} \mathrm{P}\right]-$ dATP on a Perkin-Elmer 2400 thermocycler. All components of the PCR remained the same as originally described except for a ten-fold increase in the concentration of random decamer primer $(2 \mu \mathrm{M})$. The samples were denatured at $94^{\circ} \mathrm{C}$ for $15 \mathrm{sec}$. directly preceding PCR. Parameters for the 40-cycle PCR were as follows: denaturation at $94^{\circ} \mathrm{C}$ for $15 \mathrm{sec}$., annealing at $40^{\circ} \mathrm{C}$ for $1 \mathrm{~min}$., and extension at $72^{\circ} \mathrm{C}$ for $1 \mathrm{~min}$. . At the end an additional extension at $72^{\circ} \mathrm{C}$ for $10 \mathrm{~min}$. was performed. The radiolabeled PCR-products were analyzed on $6 \%$ denaturing polyacrylamide gels.

Cloning and Sequencing. Bands identified as differentially expressed on the DD gels were excised (details in RESULTS), extracted from the acrylamide by boiling in $\mathrm{H}_{2} \mathrm{O}$ and precipitated in the presence of $0.3 \mathrm{M} \mathrm{NaOAc}, 0.5 \mathrm{mg} / \mathrm{mL}$ glycogen and four volumes of ethanol. The DNA was then reamplified using the same primer and PCR conditions as above, only the dNTP concentration was increased 10 -fold. The PCR product was cloned using the pCR-TRAP cloning system (GenHunter Corp., Brookline, MA). Cloned fragments were sequenced on a LiCor automated sequencing system using pCR-TRAP specific primers (Aidseq, GenHunter Corp., Brookline, MA).

cDNA Library Construction and Screening. Approximately $10^{8}$ cells of exponentially growing Alexandrium fundyense were harvested by centrifugation at $4,400 \mathrm{~g}$ for 5 minutes at $4^{\circ} \mathrm{C}$. The pellet was deep-frozen in liquid $\mathrm{N}_{2}$ and then 
resuspended in $20 \mathrm{~mL}$ of RNA STAT-60 (TEL-TEST "B", Inc.; TX). The suspension was placed in a $\mathrm{N}_{2}$ cell disruption bomb and the cells ruptured in three consecutive cycles of nitrogen decompression at 2,000 psi (Parr Instrument Company, Moline, IL). Homogenates were processed following the manufacturer's protocol (RNA precipitation for 1 hour) with an additional RNA precipitation in the presence of $\mathrm{NaOAc}(\mathrm{pH} 5.2$, final conc. $0.3 \mathrm{M}$ ) and two volumes of ethanol for 1 hour at $-70^{\circ} \mathrm{C}$. Approximately one $\mathrm{mg}$ of fresh total RNA was further purified for poly $(\mathrm{A})^{+}$mRNA with an oligo(dT) column (5Prime->3Prime, Inc., Boulder, CO). $5 \mu \mathrm{g}$ of poly $(\mathrm{A})^{+}$mRNA were used for construction of a lambda phage cDNA library (ZAP-cDNA cloning kit, Stratagene, La Jolla, CA). The library was further amplified $\left(2 \times 10^{5} \mathrm{pfu} / \mu \mathrm{l}\right)$ and approximately $1 \times 10^{6}$ plaques were screened on each round.

DD probes for screening the library were obtained by labeling the cloned cDNA of interest with Digoxigenin-11-dUTP (Genius Nonradioactive Nucleic Acid Labeling and Detection System, Boehringer Mannheim, IN) in a 30 cycle PCR with the following parameters: denaturation at $94^{\circ} \mathrm{C}$ for $30 \mathrm{sec}$., annealing at $52^{\circ} \mathrm{C}$ for $40 \mathrm{sec}$., and extension at $72^{\circ} \mathrm{C}$ for $1 \mathrm{~min}$. . At the end an additional extension at $72^{\circ} \mathrm{C}$ for $5 \mathrm{~min}$. was performed. The final concentration of dNTPs in the reaction mix was optimized to the following values: $20 \mu \mathrm{M}$ dATP, dCTP and dGTP respectively, $13 \mu \mathrm{M}$ dTTP and $7 \mu \mathrm{M}$ DIG-dUTP. The yield of Dig-labeled PCR product was estimated as indicated by the manufacturer and hybridizations were conducted overnight in a standard hybridization buffer $(5 \times \mathrm{SSC}$, $2 \%(\mathrm{w} / \mathrm{v})$ blocking reagent, $0.1 \% \mathrm{~N}$-lauroylsarcosine, $0.2 \% \mathrm{SDS})$, with a probe concentration of $10 \mathrm{ng} / \mathrm{mL}$ and at a temperature of $65^{\circ} \mathrm{C}$. Positive plaques were detected using the chemiluminescent substrate CSPD (Boehringer Mannheim, IN). Plaques were further purified in a second and if necessary tertiary screening, until single plaques could be isolated. The phagemid representing the cDNA of interest was then excised in vivo, 
cloned and sequenced following the manufacturer's protocols (ZAP-cDNA cloning kit, Stratagene, La Jolla, CA).

RNA Blot Analysis. Ten $\mu \mathrm{g}$ of total, DNAse treated RNA representing each of the four cell cycle stages described above, were loaded on positively charged nylon membranes (Boehringer Mannheim, IN). The DD probes were labeled as described above. Hybridizations were performed $\mathrm{O} / \mathrm{N}$ in high SDS buffer, as recommended by the manufacturer, and at $42^{\circ} \mathrm{C}$ (Genius Nonradioactive Nucleic Acid Labeling and Detection System, Boehringer Mannheim, IN). Detection of positive dots was performed as detailed above for the cDNA library screenings.

Sequence Analysis. The nucleotide sequences obtained were compared to the nonredundant GenBank, EMBL, DDBJ and PDB sequence databases using the Basic Local Alignment Search Tool program (BLAST) in its version for nucleotides (BLASTN) or aminoacids (BLASTX) (Altschul et al., 1990). The corresponding amino acid sequence was predicted using the universal genetic code. The deduced protein sequences were further characterized with the sequence analysis software program MacVector (Oxford Molecular Limited).

\section{RESULTS}

Differential Display of toxic and non-toxic Alexandrium. Differential Display of several toxic and non-toxic strains of Alexandrium tamarense and two toxic A. fundyense (see MATERIALS AND METHODS for specific strain information) was done using $\mathrm{T} 12 \mathrm{VC}$ as the degenerate oligo(dT) primer and OP-03 as the random decamer. High 
variability was observed among the DD patterns of the different strains of A. tamarense analyzed (Fig.3). Interspecific variations between A. tamarense and A. fundyense were also high (Fig. 3).

Differential Display of Synchronized Cultures of Alexandrium fundyense. Differential Display (DD) of mRNA was applied to synchronized cells of Alexandrium fundyense in different cell cycle stages and while toxin production was on or off (TaroncherOldenburg et al., 1997). Two samples were drawn during $\mathrm{G}_{1}$, one while toxin production was active (I) and a second one once toxigenesis was over (II), a third sample was constituted by cells in S phase (III), and the fourth one represented cells that were predominantly in $\mathrm{G}_{2}$ (IV) (Fig. 1). A total of 80 different anchor plus random primer combinations were used to ensure total representation of the mRNA populations (Liang et al., 1993). Twentyfour bands were identified as differentially expressed at the four time points selected. Several different expression patterns were observed. Most bands were present throughout the cell cycle (i.e. not differentially expressed), as exemplified by band D on Figure 4. Others showed cell cycle stage specific expression as was the case of band $\mathbf{E}$ on the same figure, which was induced throughout $\mathrm{G}_{1}$ but was not detectable during $\mathrm{S}$ and $\mathrm{G}_{2}$. Only those bands corresponding to genes showing suppresion, band $\mathbf{A}$, or induction, bands $\mathbf{B}$ and $\mathbf{C}$, during toxigenesis at the beginning of $\mathrm{G}_{1}$ were isolated for further characterization (Fig. 4). Three bands were singled out by these criteria, excised, cloned and subsequently used as probes to recover the corresponding cDNAs from an Alexandrium fundyense cDNA library. The DD expression patterns were also confirmed by RNA dot blot analysis (Fig. 5). The three genes were similar to Sadenosylhomocysteine hydrolase (SAHH), methionine aminopeptidase (MAP) and a histone-like protein (HAf) respectively. 
Figure 3. Comparison of inter- and intraspecific DD analysis of dinoflagellates. In the left panel, three toxic strains of Alexandrium tamarense, three non-toxic strains of $A$. tamarense and two toxic strains of A. fundyense are compared. The inter- and intrageneric variabilities are high. In contrast, in the right panel, three different cell cycle stages in synchronyzed cultures of $A$. fundyense (GtCA28) are analyzed. The patterns are identical and hence allow the identification of differentially expressed bands (Fig. 4). (The left image is a composite of lanes from one gel rearranged for clarity). 


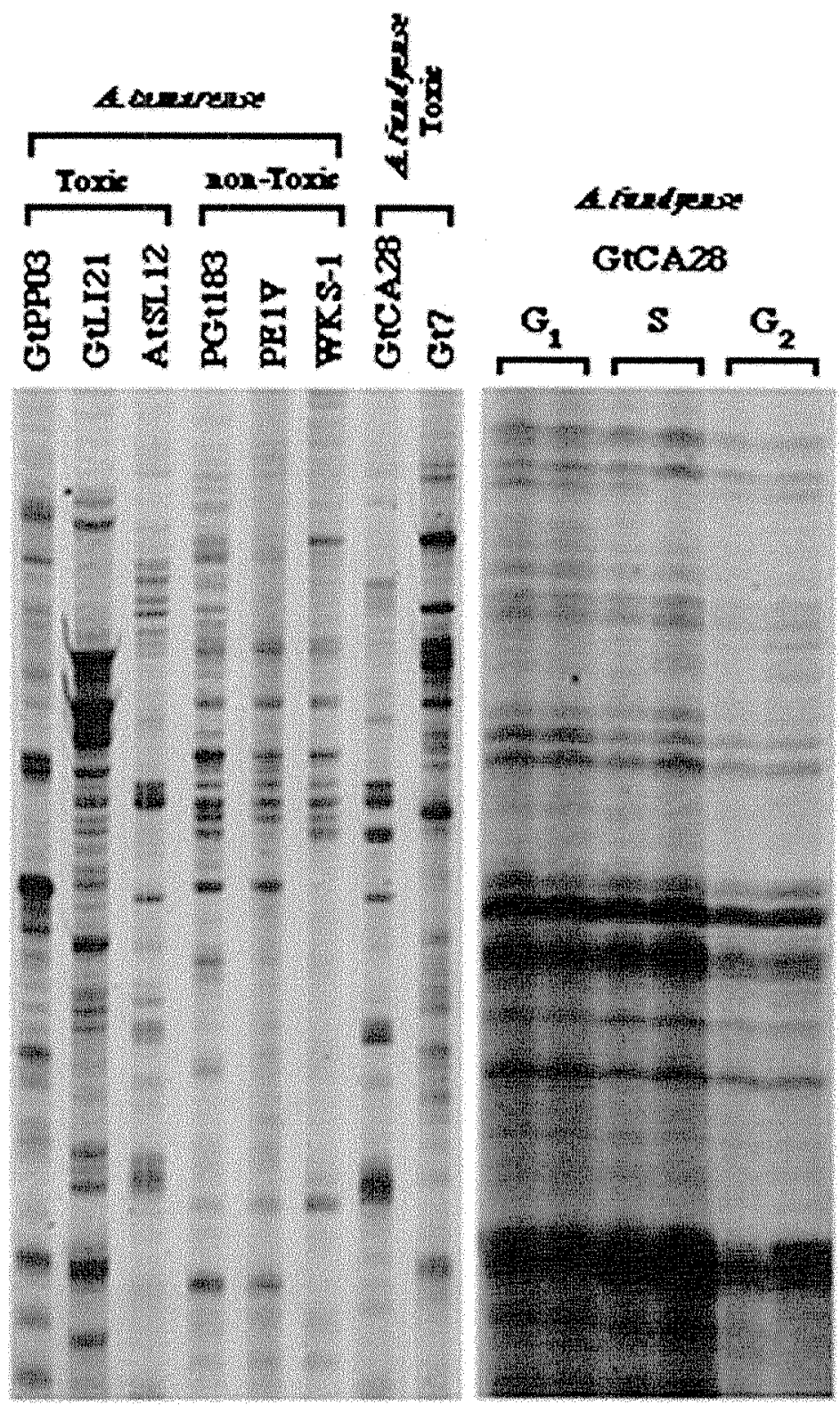


Figure 4. Differential Display comparing cells of Alexandrium fundyense in three different cell cycle stages $\left(G_{1}, S\right.$ and $\left.G_{2}\right)$ and while STX production is turned ON $(+)$ or OFF $(-)$ (Numerals I through IV refer to the four sampling points in Fig. 1; double lanes represent duplicate RT-PCRs). Band $\mathbf{A}$ is downregulated, while bands $\mathbf{B}$ and $\mathbf{C}$ are upregulated relative to toxin production. Band $\mathbf{D}$ is constitutively expressed, while band $\mathbf{E}$ is $\mathbf{G}_{1}$-specific (expressed in early and late $G_{1}$ ). 


\section{Toxin Production}
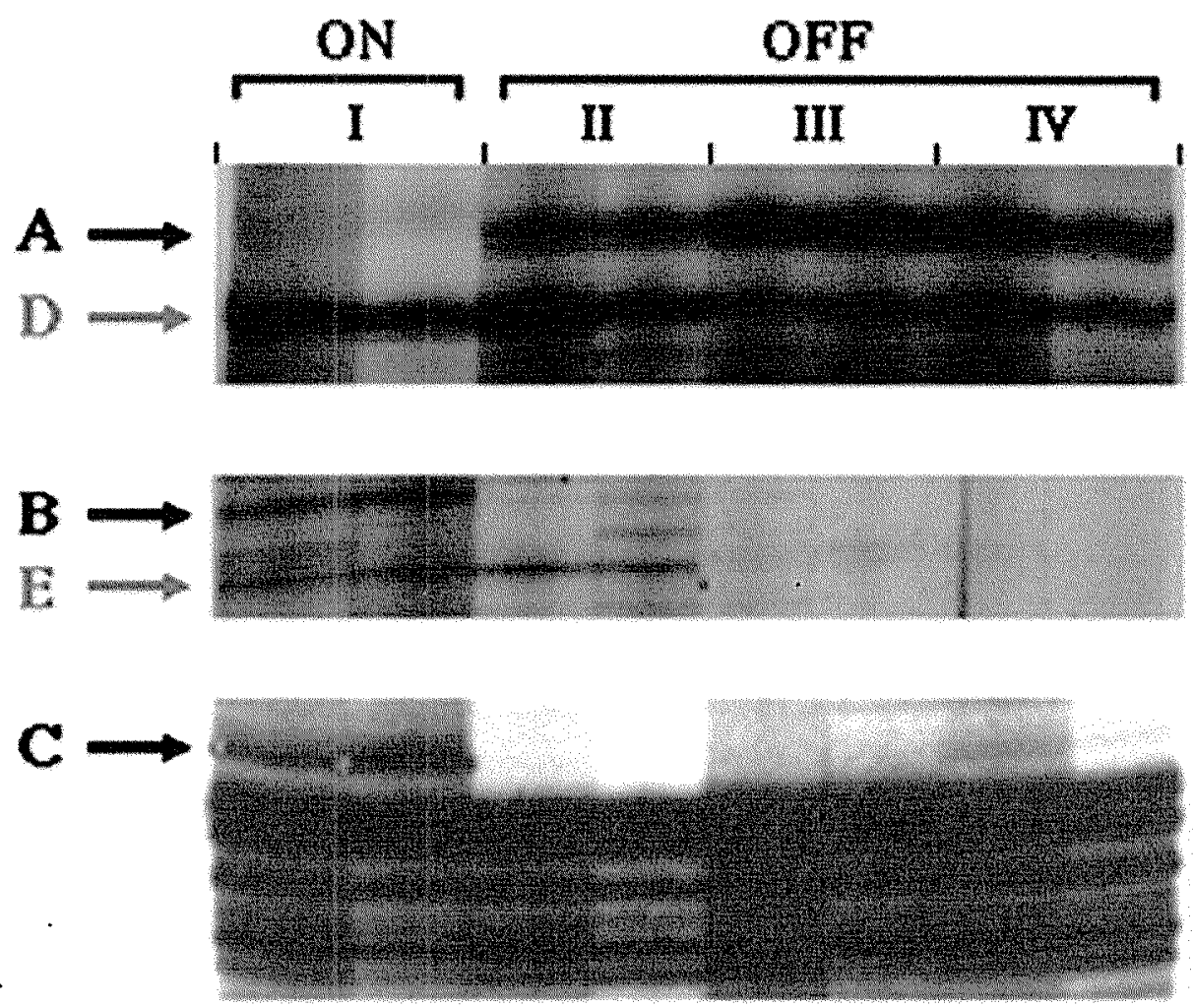
Figure 5. RNA dot blot analysis confirming the induction of DD bands $\mathbf{A}, \mathbf{B}$, and $\mathbf{C}$ in

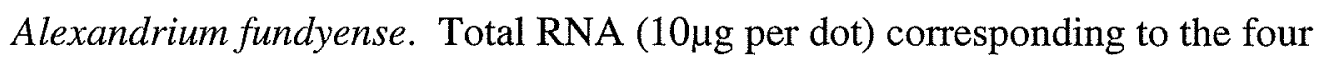
sampling points (Numerals I through IV, Fig. 1) was hybridized with cDNA probes generated by PCR of cloned cDNA fragments obtained from the differential display gels. 


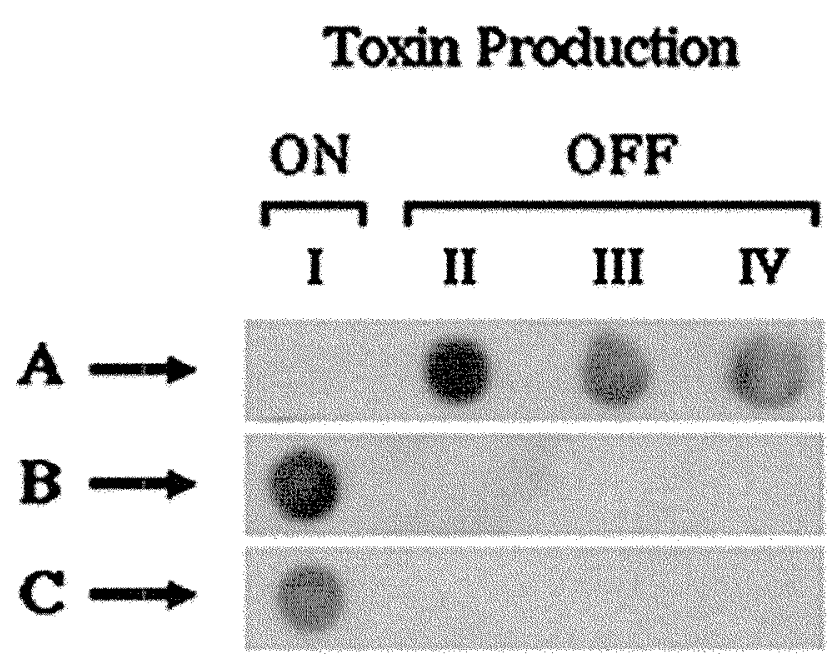


S-adenosylhomocysteine hydrolase. The $131 \mathrm{bp}$ band $\mathbf{A}$ was downregulated during toxin biosynthesis (Fig. 4). Its sequence showed that only the random decamer had been applied during the PCR amplification step of DD (Fig. 6). It has been shown previously that a significant proportion of DD bands can result from the amplification of cDNA with only one primer, either the anchored, mRNA-specific primer or the random decamer (Liang et al., 1993; Guimarães et al., 1997). These bands are equally reproducible and represent potential transcriptionally regulated genes. Such single primer bands are the result of the random decamer sequence and its inverse complement being present on the same cDNA. Generation of these bands resembles arbitrary primed PCR fingerprinting of RNA, a similar technique to DD, that relies on the use of only one primer for the generation of cDNAs representative of expressed sequences in eukaryotic and prokaryotic cells (Welsh et al., 1992; Wong and McClelland, 1994).

The alignment of the partial protein, as deduced from the rescued cDNA fragment, showed a $90 \%$ similarity with SAHHs from eukaryotes and prokaryotes (tobacco (Nicotiana sylvestris) $85 \%$ similarity, $75 \%$ identity; yeast (Schizosaccharomyces pombe) 75\% similarity, 62\% identity; a cyanobacteria (Synechocystis sp.) 63\% similarity, $44 \%$ identity) (Fig. 7).

Methionine Aminopeptidase. The $115 \mathrm{bp}$ band $\mathbf{B}$ was upregulated during toxin biosynthesis in $\mathrm{G}_{1}$ (Fig. 4). The fragment rescued from the cDNA library corresponded to the $3^{\prime}$ end of the mRNA (Fig. 8). The alignment of the deduced protein with the carboxy ends of three other MAPs showed a similarity of 70\% (yeast (Saccharomyces pombe) $61 \%$ similarity, $44 \%$ identity; a cyanobacteria (Synechocystis $s p$. ) $61 \%$ similarity, $42 \%$ identity; Escherichia coli $63 \%$ similarity, $46 \%$ identity) (Fig. 9). In addition, three of the five highly conserved copper binding regions that have been described for this 
enzyme were identified on the A. fundyense sequence (Fig. 10; shaded areas). The other two metal-binding domains fall within the missing section of the sequence.

Histone-like Protein. The $318 \mathrm{bp}$ band $\mathrm{C}$ was upregulated during toxigenesis and coinciding with the beginning of the $\mathrm{G}_{1}$ phase of the cell cycle (Fig. 4). A 577 bp cDNA with a 255 bp open reading frame (ORF) was recovered (Fig. 10). The database search aligned this sequence to two histone-like proteins from Crypthecodinium cohnii Biecheler (Fig. 11). The combined similarity was $60 \%$, with each of the two different histone-like proteins showing a similarity of $52 \%$ and an identity of $35 \%$. The ORF obtained from the cDNA library frames a protein with 85 amino acids and a molecular weight of approximately $9.3 \mathrm{kDa}$ (Fig. 10).

\section{DISCUSSION}

In this study we report the identification of several transcriptionally regulated genes that were differentially expressed throughout the cell cycle of Alexandrium fundyense and either up- or downregulated during toxigenesis. The ability to obtain cells at different times from a single culture of $A$. tamarense, while toxin production was $\mathrm{ON}$ or OFF, was essential to this study and provided an ideal system for identifying molecular factors related to toxigenesis. The advantages of using Differential Display over other techniques, such as subtractive hybridization, to identify differentially expressed genes was that it allowed the analysis of mRNAs independently of their prevalence, only required small amounts of RNA and resolved for up and downregulation simultaneously. 
Figure 6. Nucleotide and predicted amino acid sequence of the partial cDNA for a putative $S$-adenosyl-homocysteine hydrolase in $A$. fundyense. The underlined sequence represents the DD band that was originally isolated. Stars mark the two DD primer sites (A,T and A denote non-matching nucleotides on the 'random' decamer; $\mathrm{T}$ and $\mathrm{C}$ mark non-matching nucleotides on the reverse complementary sequence of the same 'random' decamer (see discussion)). 
GTG-AAC-GAC-TGC-GTG-ACA-AAG-TCC-AAG-TTC-GAT-AAT-GTG-TAC-GGG-TGC-CGT$\begin{array}{lllllllllllllllll}\mathrm{V} & \mathrm{N} & \mathrm{D} & \mathrm{C} & \mathrm{V} & \mathrm{T} & \mathrm{K} & \mathrm{S} & \mathrm{K} & \mathrm{F} & \mathrm{D} & \mathrm{N} & \mathrm{V} & \mathrm{Y} & \mathrm{G} & \mathrm{C} & \mathrm{R}\end{array}$ CAC-TCG-TTG-CCG-GAC-ATC-ATG-CGT-GCC-ACA-GAT-GTC-ATG-ATT-GGG-GGC-AAG$\begin{array}{lllllllllllllllll}\mathrm{H} & \mathrm{S} & \mathrm{L} & \mathrm{P} & \mathrm{D} & \mathrm{I} & \mathrm{M} & \mathrm{R} & \mathrm{A} & \mathrm{T} & \mathrm{D} & \mathrm{V} & \mathrm{M} & \mathrm{I} & \mathrm{G} & \mathrm{G} & \mathrm{K}\end{array}$ CGC-GCC-CTG-ATC-TGC-GGC-TAT-GGC-GAT-GTC-GGC-AAG-GGC-TGT-GCT-TTG-GCC$\begin{array}{llllllllllllllllll}R & A & L & I & C & G & Y & G & D & V & G & K & G & C & A & I & A\end{array}$ $A * * T * A * * * *$ ATG-CGC-GGA-GCC-GGA-GCC-CGT-GTC-TTG-ATT-ACC-GAG-ATT-GAC-CCA-ATC-TGC$\begin{array}{lllllllllllllllll}M & R & G & A & G & A & R & V & L & I & T & E & I & D & P & I & C\end{array}$ GCG-CTT-CAG-GCG-TGC-ATG-GAG-GGC-TTC-CAG-GTT-GTC-ACT-CTG-GAG-TCC-GTA$\begin{array}{llllllllllllllllll}A & \mathrm{~L} & \mathrm{Q} & \mathrm{A} & \mathrm{C} & \mathrm{M} & \mathrm{E} & \mathrm{G} & \mathrm{F} & \mathrm{Q} & \mathrm{V} & \mathrm{V} & \mathrm{T} & \mathrm{L} & \mathrm{E} & \mathrm{S} & \mathrm{V}\end{array}$ $* * * * \mathrm{~T}^{*} * \mathrm{C} * *$ GTT-GGG-GAG-GTG-GAT-ATT-TTT-ACG-ACG-ACC-ACG-GGC-AAC-TTC-AAG-ATC-ATC$\begin{array}{lllllllllllllllll}V & G & E & V & D & I & F & T & T & T & T & G & N & F & K & I & I\end{array}$ ACT-CTG-GAG-CAT-ATG-AAA-AAG-ATG-AAG-AAC-AAT-GCC-ATC-GTC-GGC-AAC-ATT$\begin{array}{lllllllllllllllll}T & \mathrm{~L} & \mathrm{E} & \mathrm{H} & \mathrm{M} & \mathrm{K} & \mathrm{K} & \mathrm{M} & \mathrm{K} & \mathrm{N} & \mathrm{N} & \mathrm{A} & \mathrm{I} & \mathrm{V} & \mathrm{G} & \mathrm{N} & \mathrm{I}\end{array}$ GGC-CAC-TTC-GAC-AAC-GAG-ATT-GAG-ATG-GCT-GAG-CTG-GAA-GGA-ATG-CCG-GGC$\begin{array}{lllllllllllllllll}G & H & F & D & N & E & I & E & M & A & E & L & E & G & M & P & G\end{array}$ ATC-AAG-GTG-GAG-AAC-ATC-AAG-GCA-CAG-GTT-GAC-CGC-TTC-ATA-TTC-CCA-GAT$\begin{array}{llllllllllllllllll}I & K & V & E & N & I & K & A & Q & V & D & R & F & I & F & P & D\end{array}$ GGC-CAC-GGT-ATC-ATC-GTT-CTC-GCC-TCC-GGC-CGG-CTC-TTG-AAC-TTG-GGC-TGT$\begin{array}{lllllllllllllllll}G & H & G & I & I & V & L & A & S & G & R & L & L & N & I & G & C\end{array}$ GCC-ACA-GGC-CAT-CCC-TCC-TTC-GTC-ATG-TCT-TGC-TCC-TTC-ACC-AAT-CAG-GTG$\begin{array}{llllllllllllllllll}A & T & G & H & P & S & F & V & M & S & C & S & F & T & N & Q & V\end{array}$ TTG-GAC-AAC-TTG-ACT-TTG-CTT-CAA

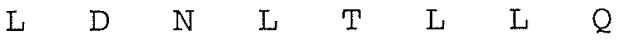


Figure 7. Partial alignment of the Alexandrium fundyense deduced $S$-adenosylhomocysteine-hydrolase amino acid sequence with those of tobacco (Nicotiana sylvestris), yeast (Schizosaccharomyces pombe) and a cyanobacterium (Synechocystis sp.). Boxes denote higher than 50\% identity (Bold letters) or similarity (Plain letters) among the four oganisms. 
A. fundyense N. sylvestris

S. pombe

Synechocystis

A. fundyense N. sylvestris

S. pombe

Synechocystis

A. fundyense N. sylvestris

S. pombe

Synechocystis

A. fundyense N. sylvestris

S. pombe

Synechocystis

A. fundyense N. sylvestris

S. pombe

Synechocystis

A. fundyense N. sylvestris

S. pombe

Synechocystis

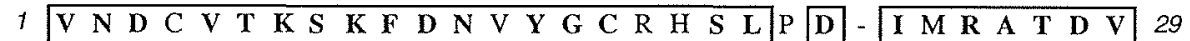

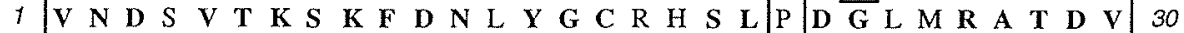

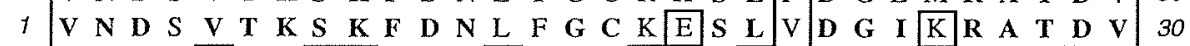

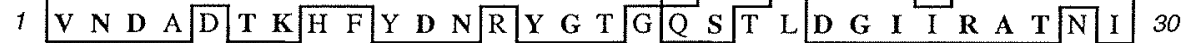

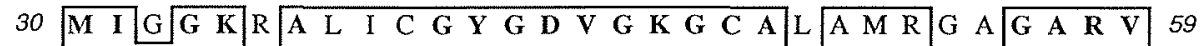

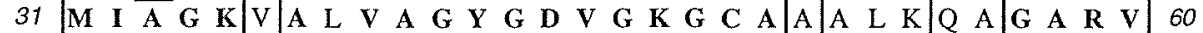

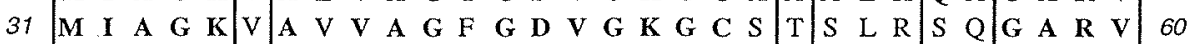

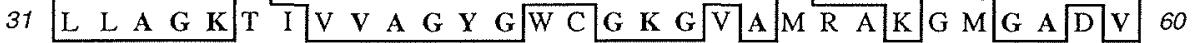

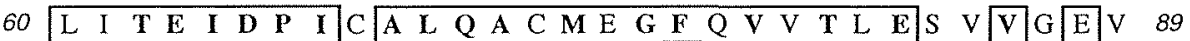

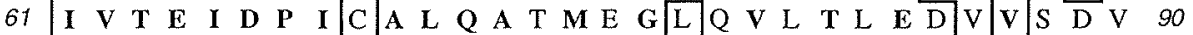

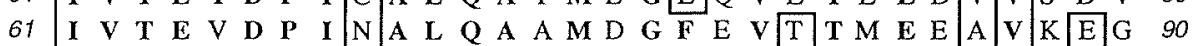

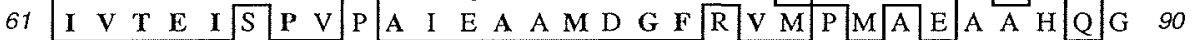

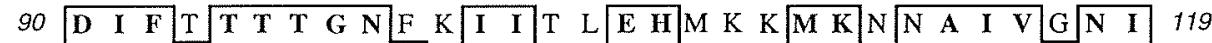

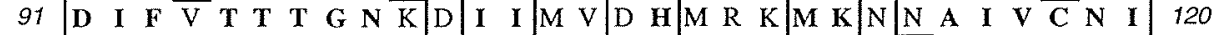

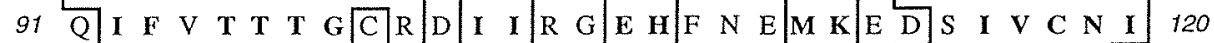

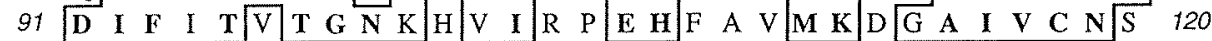

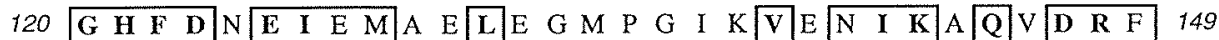

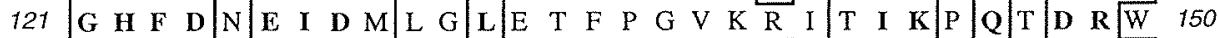
121 G 121 G H H F

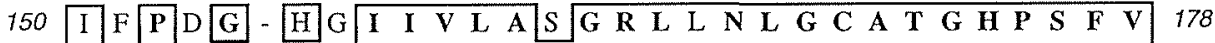

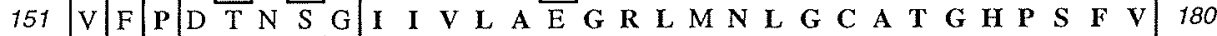

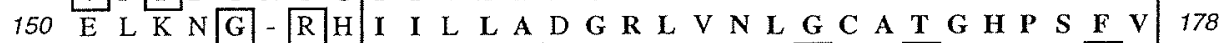

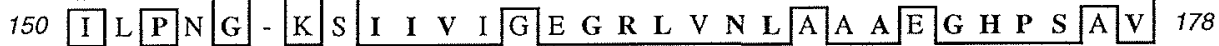

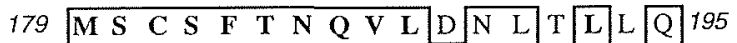
\begin{tabular}{llllllllllllll|l|l|l|l|l}
181 & M S & C & $S$ & F & T & N & Q & V & I & A & Q & L & E & L & W & K & 197
\end{tabular} 179 M S C C S 179 M D M S F A N Q A L L A C E E H L V V 
Figure 8. Nucleotide and predicted amino acid sequence of the $3^{\prime}$ end of a cDNA encoding for a putative methionine aminopeptidase in A. fundyense. The nucleotides in lower-case correspond to non-encoding regions on the $3^{\prime}$ end of the cDNA strand. The underlined sequence represents the DD band that was originally isolated. Stars mark the two DD primer sites $(\mathrm{C}$ and $\mathrm{C}$ denote non-matching nucleotides on the 'random' decamer; V stands for A,C or G in the anchored primer). The italicized triplet (TGA) represents the first STOP codon encountered. 


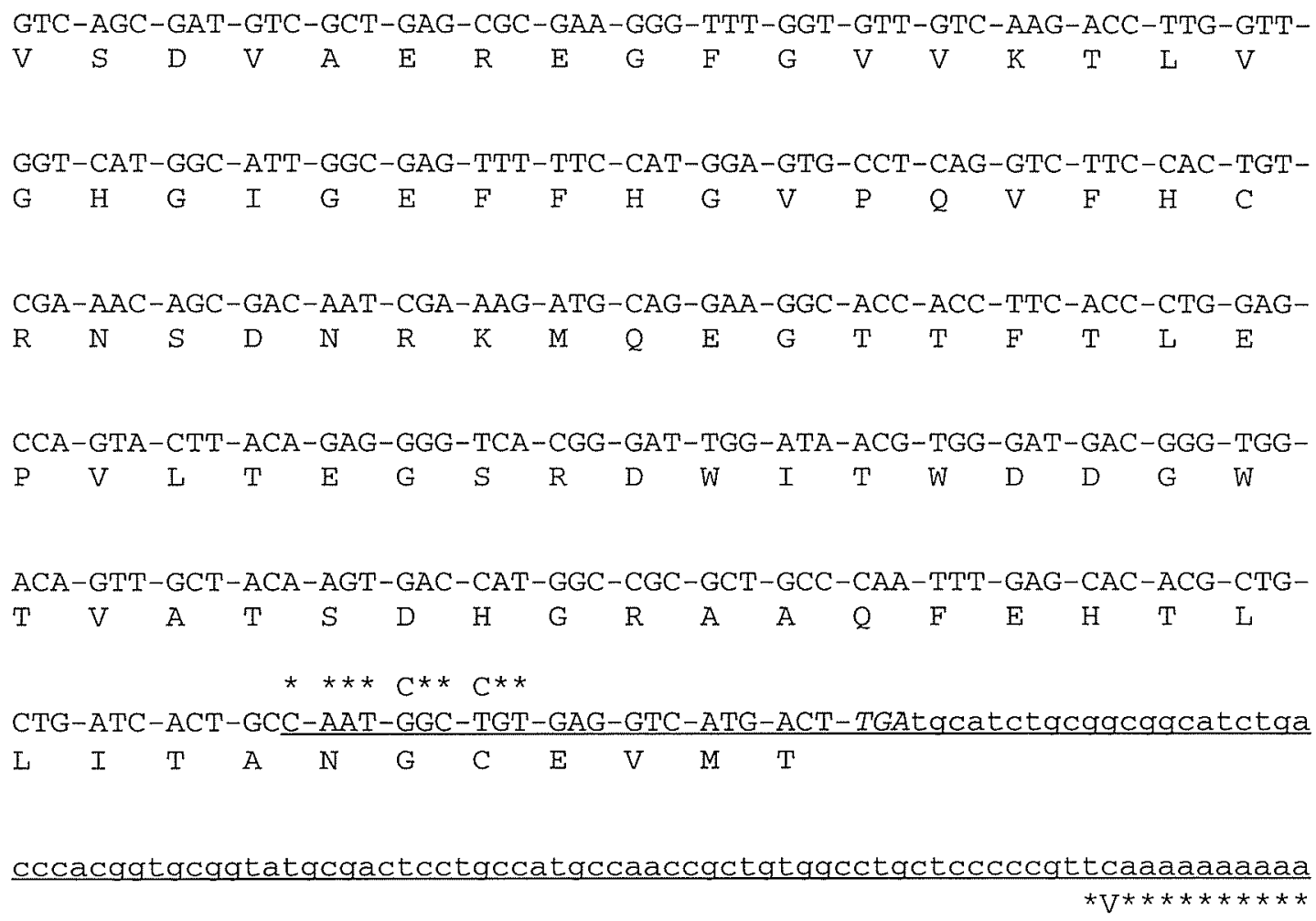


Figure 9. Partial alignment of the Alexandrium fundyense deduced methionine aminopeptidase amino acid sequence with those of yeast (Saccharomyces pombe), a cyanobacteria (Synechocystis sp.) and Escherichia coli. The shaded areas correspond to three of the five highly conserved copper binding regions that have been described for this enzyme (see text). Boxes denote higher than 50\% identity (Bold letters) or similarity (Plain letters) among the four organisms. 


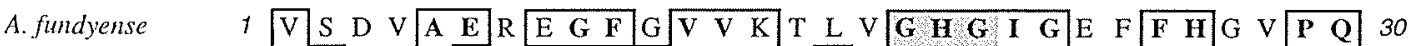

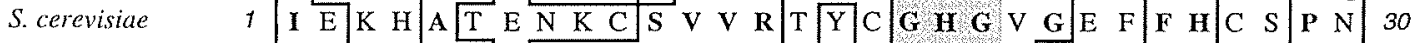

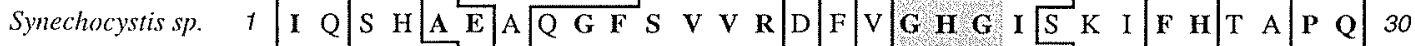

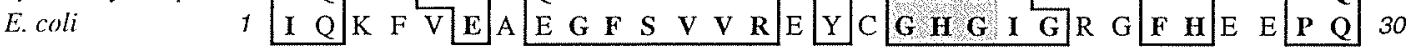

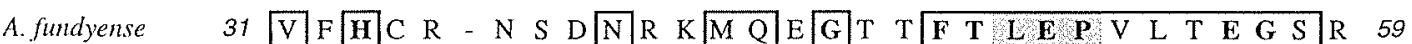

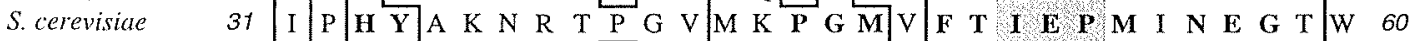
\begin{tabular}{ll|l|llllllll|ll|lllll|lllllllllllllll} 
Synechocystis sp. & 31 & I & P & H & Y & G & $K$ & A & G & K & G & K & R & L & R & P & G & M & V & F & T & I & E & P & M & I & N & E & G & T & W & 60
\end{tabular}

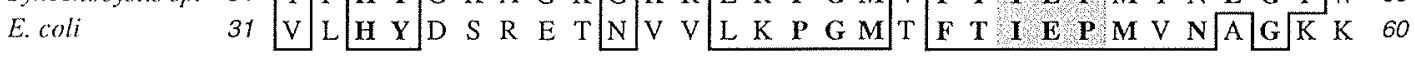

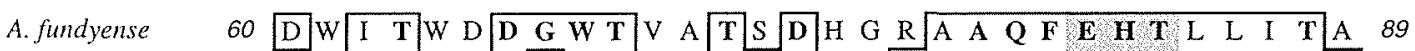

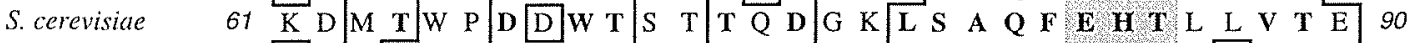

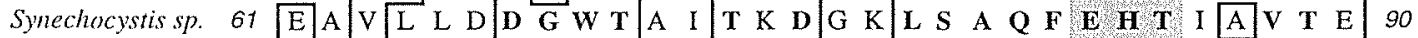

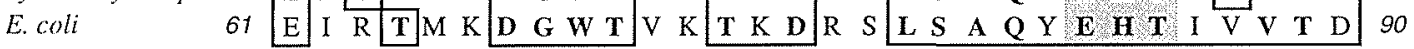

A. fundyense $\quad 9 0 \longdiv { \mathrm { N } \mathrm { G } } \mathrm { C } \mathbf { \mathrm { E } } \mathrm { V } \mathrm { M } \mathrm { T } \quad 9 6$

$\begin{array}{lllllllllllllllllllllllll}\text { S. cerevisiae } & 91 & \text { H } & \text { G } & \text { V } & \text { E } & \text { I } & \text { L } & \text { T } & \text { A } & R & N & K & K & S & P & G & G & P & R & Q & R & I & K & 112\end{array}$

Synechocystis sp. 91 D $\mathrm{G}$ V V

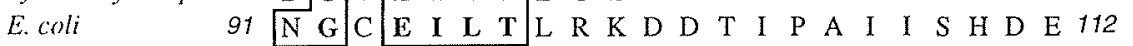


Figure 10. Nucleotide sequence of the ORF encoding for a putative histone-like protein in A. fundyense. The nucleotides in lower-case correspond to non-encoding regions on the $5^{\prime}$ and $3^{\prime}$ ends of the cDNA strand. The underlined sequence represents the DD band that was originally isolated. Stars mark the two DD primer sites ( $\mathrm{T}, \mathrm{G}$ and $\mathrm{C}$ denote non-matching nucleotides on the 'random' decamer; $\mathrm{V}$ stands for $\mathrm{A}, \mathrm{C}$ or $\mathrm{G}$ in the anchored primer). The italicized triplet $(T A G)$ represents the first STOP codon encountered. 
cacgagccegttcg-ATG-AGC-CCC-TCG-GCG-ACC-AGA-TCC-CGG-ACG-CGA-ACA-GCG-
$M$

GGG-GCA-TCT-CGC-AGG-ACA-AGG-CTG-CGG-ACA-AGT-TCT-GCC-AGA-GGT-TCT-GCC$\begin{array}{lllllllllllllllll}\mathrm{G} & \mathrm{A} & \mathrm{S} & \mathrm{R} & \mathrm{R} & \mathrm{T} & \mathrm{R} & \mathrm{L} & \mathrm{R} & \mathrm{T} & \mathrm{S} & \mathrm{S} & \mathrm{A} & \mathrm{R} & \mathrm{G} & \mathrm{S} & \mathrm{A}\end{array}$

CGA-GCT-CCG-GTT-GCC-ACT-GCG-GAG-GTG-AAG-AAG-TTG-GGC-GTC-TTC-ACT-GTC$\begin{array}{lllllllllllllllll}\mathrm{R} & \mathrm{A} & \mathrm{P} & \mathrm{V} & \mathrm{A} & \mathrm{T} & \mathrm{A} & \mathrm{E} & \mathrm{V} & \mathrm{K} & \mathrm{K} & \mathrm{L} & \mathrm{G} & \mathrm{V} & \mathrm{F} & \mathrm{T} & \mathrm{V}\end{array}$

CCA-GGC-CCC-TAC-AAT-ATC-AAG-TTG-AGG-GAG-AAG-CCC-GCC-ACC-CAG-GCC-AGC$\begin{array}{lllllllllllllllll}\mathrm{P} & \mathrm{G} & \mathrm{P} & \mathrm{Y} & \mathrm{N} & \mathrm{I} & \mathrm{K} & \mathrm{L} & \mathrm{R} & \mathrm{E} & \mathrm{K} & \mathrm{P} & \mathrm{A} & \mathrm{T} & \mathrm{Q} & \mathrm{A} & \mathrm{S}\end{array}$

AAG-TGG-AAG-GTG-TGC-CTG-AGA-GTG-GCC-TGG-CAT-GTA-TTC-CCT-TTA-AAG-GCT$\begin{array}{llllllllllllllllll}K & W & K & V & C & L & R & V & A & W & H & V & F & P & L & K & A\end{array}$

** $* \mathrm{~T} * \mathrm{G} * \mathrm{C} * *$

TGC-AAG-CTC-TGT-TAGagcatcaggctgaagagctttgcttggaattgcaactggagcagcagga

$\mathrm{C} \quad \mathrm{K}$ I $\mathrm{C}$

ggctcatctacaggctcttctegcgcttccgatcctgggccetctaaggagaagaaggocaagatgaaaag tagoaagtgatgccogtgatgttgctcagctccagtgqcetgctctcagagttgatttgctaggtcagtcat tttgaactctgtgatgtgcattctgcacgcagtattacttgtaaatctctcaggcoatcctcttcattac attqtotgqagqcoqattaaqacqttotcaaaaaaaaaaaaaaaaaaaaaa

$\star V * * * * * * * * * *$ 
Figure 11. Alignment of the deduced amino acid sequence of the Alexandrium fundyense histone-like protein with two different histone-like protein sequences from Crypthecodinium cohnii. Boxes denote higher than 50\% identity (bold letters) or similarity (plain letters) among the three sequences. 


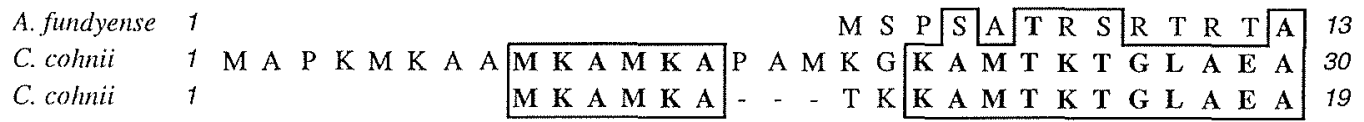

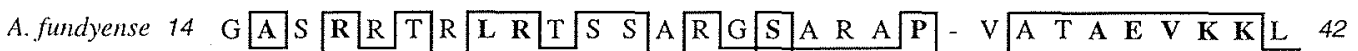

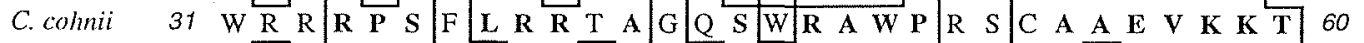

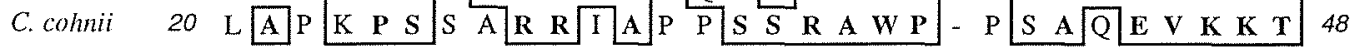

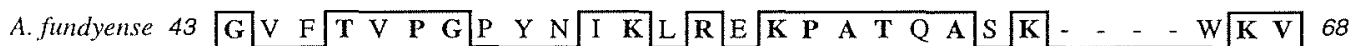

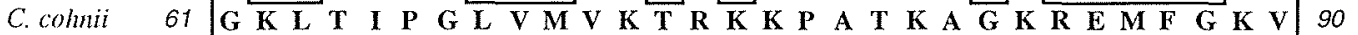

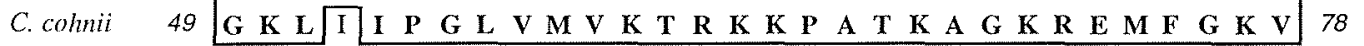

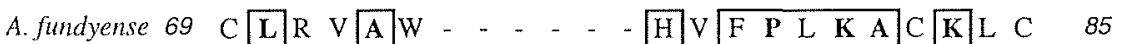

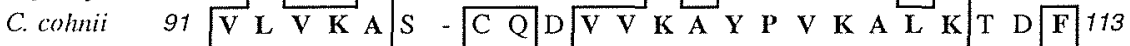

$\begin{array}{llllllllllllllllllllllllllll}\text { C. colmii } & 79 & \text { V } & \text { L } & \text { V } & \text { K } & \text { A } & \text { Q } & \text { P } & \text { A } & \text { K } & \text { T } & \text { V } & \text { V } & \text { K } & \text { A } & \text { Y } & \text { P } & \text { V } & \text { K } & \text { A } & \text { L } & \text { K } & \text { D } & \text { N } & \text { F } & 102\end{array}$ 
Synchronized Growth and Differential Display. The application of Differential Display (DD) to the identification of genes that are expressed during toxin production in Alexandrium sp., and hence potentially related to toxin biosynthesis, was contingent on the design of a system that would allow the comparison of toxin-producing and nonproducing cells. Two experimental setups were possible: First, phylogenetically close toxic and non-toxic strains of Alexandrium sp. could be compared; alternatively, cells of a single isolate collected in different physiological stages relative to toxin production could be analyzed. As discussed previously, mutant formation was not a realistic option.

Extensive work has been done on the phylogeny of the Alexandrium group using ribosomal RNA gene sequences (Scholin et al., 1995). Based on the phylogenetic distance information we ran some DD gels comparing toxic and non-toxic strains of Alexandrium tamarense that were closely related, but their genetic variation was still large enough as to make it impossible to identify differentially expressed genes over the general variation between DD patterns due to inter-strain dissimilarities (Fig. 3). Variations in DD patterns arise from differences in the nucleotide sequences of the mRNAs. Changes in just one nucleotide in the region binding to the DD primers can result in no annealing of a specific primer, and hence no amplification of the mRNA. This same mRNA might be amplified by a different set of primers. Therefore, the absence of a specific band does not mean that the corresponding gene is not expressed but that it is not amplified by this particular set of primers. The similarity among the DD patterns has to be of at least $90-95$ per cent to make the comparison meaningful. Variabilities of the magnitude observed in Figure 3 result in an impossibility to make any prediction about the actual regulation of the genes identified as differentially expressed because of the uncertainty about the identity between similar bands. Interspecific variations between A. tamarense and A. fundyense were equally uninformative (Fig. 3). 
The sensitivity of DD to changes in sequences was such that the cells to be compared had to be truly identical in their genetic makeup to avoid a noisy background.

The alternative was to take advantage of the discontinuity in toxin biosynthesis over the cell cycle in synchronously growing cells of $A$. fundyense that we had previously reported (Taroncher-Oldenburg et al., 1997). When we performed DD on samples drawn at different times throughout the cell cycle, the patterns of the reverse transcribed and amplified mRNA components analyzed were largely identical, resulting in a uniform background over which specific, differentially expressed genes could be identified (Figs. $3 \& 4)$

S-Adenosylhomocysteine Hydrolase. The enzyme $S$-adenosylhomocysteine hydrolase $(\mathrm{SAHH})$ has a key role in the regulation of the S-adenosylmethionine (SAM) pathway, one of the main elements of one-carbon metabolism in the cell. It catalyzes the reversible cleavage of $S$-adenosylhomocysteine, the side product of SAM-mediated methylation reactions, into adenosine and homocysteine. The equilibrium of this reaction lies distinctly in favor of the synthesis of $S$-adenosylhomocysteine. The homocysteine resulting from the cleavage reaction is subsequently remethylated to yield methionine. This last reaction is catalyzed by homocysteine methyltransferase, a methyltetrahydrofolate dependent enzyme. In the closing step of the SAM cycle, methionine is reactivated by binding to ATP to form SAM. By virtue of its reversibility, the function of the SAHH is to control the recycling of $S$-adenosylhomocysteine into the SAM cycle to ensure a steady supply of homocysteine for its transmethylation into methionine. Similarily to our observation in Alexandrium fundyense, this enzyme has also been found to be transcriptionally regulated in other organisms. SAHH expression is induced by pathogenic attack in parsely (Kawalleck et al., 1992) and differentially expressed over the progression of developmental stages in lucerne (Abrahams et al., 1995). 
The connection SAHH downregulation in A. fundyense might bear to STX biosynthesis lies in the postulated presence of one SAM dependent methylation step in the early phases of the synthesis of the STX backbone (Shimizu, 1993). By regulating the supply of SAM, this pathway could limit or enhance the activity of the toxigenic enzymes. Such a correlation, though, would most probably be non-specific for toxin biosynthesis, since SAM is involved in a wide spectrum of anabolic processes in the cell.

Methionine Amino Peptidase. Methionine aminopeptidase (MAP) is responsible for cleaving the amino-terminal methionine during processing of most nascent proteins. It is cobalt dependent and its active site contains two zinc ion binding domains (Arfin et al., 1995). The partial Alexandrium sequence reported here contains three of the five highly conserved domains responsible for its metal-binding character. The function of this enzyme in other organisms clearly relates to regulation of protein synthesis and enzyme activities in general and is essential for the viability of the organism. MAPs are present and active throughout the entire life cycle of a cell. Depending on the organism, the number of different MAPs in a cell can vary depending on the developmetal status or cell cycle stage of the cell (Arfin et al., 1995). Regulation further happens at both the transcriptional and post-translational levels in different organisms (Arfin et al., 1995).

Protein biosynthesis regulation at this primary level might have a direct influence on toxin biosynthesis via complex interactions between different components of the general cellular metabolism, but no straight correlation to STX biosynthesis can be inferred. Other scenarios cannot be completely excluded as recent reports have shown that in addition to its protein editing function, MAP also acts as an inhibitor of eukaryotic initiation factor $2 \alpha$ (elF-2 $\alpha$ ) phosphorylation and is involved in regulation of angiogenesis in higher eukaryotes (Griffith et al., 1997), implying that not all the functions of this gene are known yet. 
Histone-like Protein. Dinoflagellate nuclei are unique among eukaryotes in that their chromosomes remain condensed throughout the entire cell cycle, in contrast to the unwinding and relaxation of the chromatin observed in all other eukaryotic organisms (reviewed (Rizzo, 1991)). In addition to this, dinoflagellates also lack the typical histone proteins and nucleosome structures that define typical nuclei of other eukaryotic organisms (Herzog and Soyer, 1981; Rizzo, 1981). Nonetheless, dinoflagellate chromosomes have been shown to contain an alternative suite of basic proteins, the so called histone-like proteins (Rizzo and Morris, 1984; Rizzo, 1987). No clear function has been adscribed to these proteins yet, but the evidence gathered so far suggests that rather than having an intrinsic structural or stabilizing function they might be involved at some level in transcriptional regulation or, perhaps, initiation (Sala-Rovira et al., 1991).

Band $\mathbf{C}$ of the Differential Display analysis rescued a full-length cDNA with a high similarity at the amino acid level with histone-like proteins from the dinoflagellate Crypthecodinium cohnii. Differential or cyclic 'de novo' synthesis of histone-like proteins in C. cohnii has been suggested based on immunocytochemical studies (Géraud et al., 1991). No information is available on histone-like proteins in A. fundyense.

No direct correlation can be drawn in this case between the induction of the histonelike protein and STX biosynthesis. On the other hand, the isolation of this protein illustrates the fact that DD analysis of any population of synchronized cells is, by definition, an ideal system to identify genes related to cell cycle progression. As mentioned above, histone-like proteins are closely associated to DNA and its structure or some of its functions, which means that its biosynthesis is probably regulated in a DNA or cell cycle dependent manner. Cell cycle-dependent expression has, for example, been shown for histones in plants (Callard and Mazzolini, 1997). 
Regulation of STX biosynthesis. Biosynthetic pathways can be regulated at many different levels. Expression of a specific enzyme can be regulated at the transcriptional level, through the induction or suppresion of gene transcription itself, or at the pretranslational level, which includes mRNA editing, regulation of translation and posttranslational mechanisms such as protein maturation and enzyme inhibition. Not much is known about regulation of STX biosynthesis in dinoflagellates. Enhancement and inhibition of toxigenesis have been shown under varying environmental conditions (Hall, 1982; Boyer et al., 1987; Anderson et al., 1990). Toxin content and variations in generation time or length of the cell cycle have been suggested to be correlated (Anderson et al., 1990). More recently, STX biosynthesis has also been shown to be coupled to the $\mathrm{G}_{1}$ phase of the cell cycle (Taroncher-Oldenburg et al., 1997). All this evidence led us to the hypothesis that STX biosynthesis might be regulated in a cell cycle-dependent manner.

Many cell cycle-dependent genes are known to be transcriptionally regulated in eukaryotes (Price et al., 1991; Callard and Mazzolini, 1997). Based on this and our ability to synchronize cultures of Alexandrium fundyense, we set out to identify genes regulated in patterns that correlated with episodes of toxigenesis during the early part of the $G_{1}$ phase of the cell cycle. The results of this search were expected to fall within one of four possible categories: (1) Gene products which could be involved in one of the proposed steps of STX biosynthesis (Shimizu, 1993); (2) genes with known, cell cycle related functions (Callard and Mazzolini, 1997); (3) genes encoding regulatory factors, cell cycle related or not, that could potentially activate toxin production (Tandeau de Marsac and Houmard, 1993; Van Dolah et al., 1995; Custer et al., 1997); and (4) novel genes with unknown functions that could be related to toxigenesis and/or cell cycle progression (Joseph et al., 1994; Utans et al., 1994). None of the three genes we isolated seemed to specifically relate to STX biosynthesis. One gene, encoding the putative 
histone-like protein HAf, could be a cell cycle-related gene since it encodes for a protein that is surmised to have DNA structural and regulatory functions. The two other genes, $\mathrm{SAHH}$ and MAP, are both involved in regulatory pathways. One, MAP, acts at the more general level of post-translational regulation. The other, $\mathrm{SAHH}$, regulates the supply of methylating units, SAM, in the cell and hence affects not just the methylation step in STX biosynthesis but also other methyl-dependent pathways in the cells. No genes with unknown functions were isolated.

From the results presented here we can conclude several things related to STX biosynthesis and its regulatory mechanism in Alexandrium fundyense. First, and despite the fact that we did not identify specific enzymes for STX biosynthesis, we cannot exclude the possibility that this process is still transcriptionally regulated. DD is the most reliable and representative method available to identify transcriptionally regulated genes in eukaryotes, but it is based on PCR and thereby introduces a statistical probability of missing and not amplifying rare transcripts (Liang et al., 1993; Wan et al., 1996). Secondly, the genes involved in STX biosynthesis could be post-transcriptionally regulated. This could happen at the translational level, in which case the stable transcripts could be present throughout the cell cycle and only translated at specific times, or it could be regulated at the post-translational level.

Few data exist on genetic regulation in dinoflagellates. The best studied system is the regulation of luciferin binding protein (LBP) in Gonyaulax polyedra (Machabée et al., 1994; Mittag et al., 1994). The synthesis of LBP is under circadian control and its corresponding mRNA is present throughout the cell cycle. Translation is repressed in the presence of a protein that binds specifically to a $3^{\prime}$-untranslated region (UTR) of the mRNA. The regulation of two other families of proteins, the peridinin chlorophyll- $a$ binding proteins (PCPs) and the chlorophyll-a-c binding proteins (ACPs), has been studied at a physiological level similar to STX production (Jovine et al., 1992; Triplett et 
al., 1993; Johnsen et al., 1994). The activation pattern of the cell cycle regulatory protein CDC2 kinase has been characterized in Gambierdicus toxicus (Van Dolah et al., 1995). CDC2 kinase is constitutively expressed throughout the cell cycle and activated only in mitotic cells. Evidence for the presence of this ubiquitous regulator of cell cycle progression in eukaryotes has also been gathered in Crypthecodinium cohnii (Rodriguez et al., 1994).

The common denominator to all the previous systems is translational regulation. In this study we show for the first time that transcriptional or pre-translational regulation does indeed occur in dinoflagellates. Previous reports had suggested the possibility that translational mechanisms could be the primary means of circadian regulation in these organisms (Milos et al., 1990). We have shown not only the induction or suppression of the three genes described here, but also observed transcriptional or pre-translational regulation of about twenty other genes with varying DD patterns (e.g., band E, Fig. 4).

Differential Display and Dinoflagellates. This study illustrates the potential of applying Differential Display to the identification of transcriptionally regulated genes in dinoflagellates and other phytoplankton. Many of these organisms cannot be cultivated or, when finally cultivated, do not produce enough material for traditional molecular studies. This is not a problem with DD due to the amplification step inherent to the method. DD also circumvents the need to create mutants for the analysis of specific genetic functions. In this study, we adapted DD to the analysis of different cell cycle stages in Alexandrium. Other applications include the study of different life cycle stages of phytoplankton or the isolation of specific genes induced by environmental stresses. Examples for these applications on higher eukaryotes already exist in the literature. Sexual-stage specific mRNAs have been isolated in Eimeria bovis, a parasitic protozoan, and genes involved in the different steps of hematopoiesis have been identified in mouse 
(Abrahamsen et al., 1995; Guimarães et al., 1997). Tissue specific markers have been observed in the rhodophyte Porphyra perforata (Hong et al., 1995). Genes induced by ozone stress in Arabidopsis thaliana and genes induced by phosphate depletion in rat kidney have been isolated (Sharma and Davis, 1995; Custer et al., 1997).

In conclusion, transcriptional or translational mechanisms could underly the regulation of STX biosynthesis, but it will be necessary to gather more information on the biosynthetic pathway in order to identify the enzymes involved and study their expression patterns as well as those of the inferred genes. This study has also documented the potential of applying DD to the identification of genes that are related to certain physiological or developmental processes in phytoplankton. 


\section{REFERENCES}

Abrahams, S., Hayes, C. M. and Watson, J. M. (1995) Expression patterns of three genes in the stem of lucerne (Medicago sativa) Plant Mol. Biol. 27, 513-28.

Abrahamsen, M. S., Johnson, R. R., Hathaway, M. and White, M. W. (1995) Identification of Eimeria bovis merozoite cDNAs using differential mRNA display Mol. Biochem. Parasitol. 71, 183-191.

Altschul, S. F., Gish, W., Miller, W., Myers, E. W. and D.J., L. (1990) Basic local alignment search tool J. Mol. Biol. 215, 403-10.

Anderson, D. M. (1989) Toxic algal blooms and red tides: A global perspective. In Red tides: Biology, Environmental science, and toxicology, ed. Okaichi, Anderson, D. M. and Nemoto, pp. 11-16. Elsevier Science Publishing, New York.

Anderson, D. M., Kulis, D. M., Sullivan, J. J., Hall, S. and Lee, C. (1990) Dynamics and physiology of saxitoxin production by the dinoflagellates Alexandrium spp. Mar. Biol. 104, 511-524.

Arfin, S. M., Kendall, R. L., Hall, L., Weaver, L. H., Stewart, A. E., Matthews, B. W. and Bradshaw, R. A. (1995) Eukaryotic methionyl aminopeptidases: Two classes of cobalt-dependent enzymes PNAS USA 92, 7714-8.

Boyer, G. L., Sullivan, J. J., Andersen, R. J., Harrison, P. J. and Taylor, F. J. R. (1987) Effects of nutrient limitation on toxin production and composition in the marine dinoflagellate Protogonyaulax tamarensis Mar. Biol. 96, 123-128.

Callard, D. and Mazzolini, L. (1997) Identification of proliferation-induced genes in Arabidopsis thaliana. Characterization of a new member of the highly evolutionarily conserved histone H2A.F/Z variant subfamily Plant Physiol. 115, $1385-95$.

Custer, M., Spindler, B., Verrey, F., Murer, H. and Biber, J. (1997) Identification of a new gene product (diphor-1) regulated by dietary phosphate Am. J. Physiol. 273, F801-6.

Géraud, M.-L., Herzog, M. and Soyer-Gobillard, M. O. (1991) Nucleolar localization of rRNA coding sequences in Prorocentrum micans Ehr. (dinomastigote, kingdom protoctist) by in situ hybridization Biosys. 26, 61-74.

Griffith, E. C., Su, Z., Turk, B. E., Chen, S., Chang, Y. H., Wu, Z., Biemann, K. and Liu, J. O. (1997) Methionine aminopeptidase (type 2) is the common target for angiogenesis inhibitors AGM-1470 and ovalicin Chem. Biol. 4, 461-71.

Guillard, R. R. L. and Ryther, J. H. (1962) Studies of marine phytoplanktonic diatoms. Cyclotella nana Hustedt and Detonula confervacea (Cleve) Gran. Can. J. Microbiol. 8, 229-239. 
Guimarães, M. J., McClanahan, T. and Bazán, J. F. (1997) Application of differential display in studying developmental processes. In Differential Display Methods and Protocols, ed. Liang, P. and Pardee, A. B., pp. 175-194. Humana Press Inc., Totowa, NJ.

Hall, S. (1982) Toxins and toxicity of Protogonyaulax from the northeast Pacific, Ph.D., Univ. of Alaska.

Hall, S., Strichartz, G., Moczydlowski, E., Ravindran, A. and Reichardt, P. B. (1990) The saxitoxins: sources, chemistry and pharmacology 29-65.

Herzog, M. and Soyer, M. O. (1981) Distinctive features of dinoflagellate chromatin. Absence of nucleosomes in a primitive species, Prorocentrum micans E. Eur. J. Cell. Biol.

Hong, Y.-K., Sohn, C. H., Polne-Fuller, M. and Gibor, A. (1995) Differential Display of tissue-specific messenger RNAs in Porphyra perforata (Rhodophyta) thallus $J$. Phycol. 31, 640-643.

Johnsen, G., Nelson, N. B., Jovine, R. V. M. and Prézelin, B. B. (1994) Chromoprotein- and pigment-dependent modeling of spectral light absorption in two dinoflagellates Mar. Ecol. Prog. Ser. 114, 245-258.

Joseph, R., Dou, D. and Tsang, W. (1994) Molecular cloning of a novel mRNA (neuronatin) that is highly expressed in neonatal mammalian brain Biochem. Biophys. Res. Comm. 201, 1227-1234.

Jovine, R. V. M., Triplett, E. L., Nelson, N. B. and Prézelin, B. B. (1992) Quantification of chromophore pigments, apoprotein abundance and isoelectric variants of peridinin-chlorophyll- $a$ protein complexes (PCPs) in the dinoflagellate Heterocapsa pygmea grown under variable light conditions Plant Cell Physiol. 33, 733-741.

Kawalleck, P., Plesch, G., Hahlbrock, K. and Somssich, I. E. (1992) Induction by fungal elicitor of S-adenosyl-L-methionine synthetase and S-adenosyl-Lhomocysteine hydrolase mRNAs in cultured cells and leaves of Petroselinum crispum PNAS USA 89, 4713-7.

Kodama, M., Ogata, T. and Sato, S. (1988) Bacterial production of saxitoxin Agric. Biol. Chem. 52, 1075-1077.

Liang, P., Averboukh, L. and Pardee, A. B. (1993) Distribution and cloning of eukaryotic mRNAs by means of differential display: refinements and optimization Nucleic Acids Res. 21, 3269-3275.

Liang, P. and Pardee, A. B. (1992) Differential display of eukaryotic messenger RNA by means of the polymerase chain reaction Science 257, 967-971.

Machabée, S., Wall, L. and Morse, D. (1994) Expression and genomic organization of a dinoflagellate gene family Plant Mol. Biol. 25, 23-31. 
Milos, P., Morse, D. S. and Hastings, J. W. (1990) Circadian control over synthesis of many Gonyaulax proteins is at a translational level Naturwis. 77, 87-89.

Mittag, M., Lee, D.-H. and Hastings, J. W. (1994) Circadian expression of the luciferin-binding protein correlates with the binding of a protein to the $3^{1}$ untranslated region of its mRNA Proc. Natl. Acad. Sci. 91, 5257-5261.

Negri, A. P., Jones, G. J., Blackburn, S. I., Oshima, Y. and Onodera, H. (1997) Effect of culture and bloom development and of sample storage on paralytic shellfish poisons in the cyanobacterium Anabaena circinalis $J$. Phycol. 33, 26-35.

Oshima, Y. (1995) Chemical and enzymatic transformation of paralytic shellfish toxins in marine organisms. In Harmful Marine Algal Blooms, ed. Lassus, P., Arzul, G. and Erard, E., pp. 475-480. Lavoisier, Paris.

Oshima, Y., Blackburn, S. I. and Hallegraeff, G. M. (1993) Comparative study on paralytic shellfish toxin profile of the dinoflagellate Gymnodinium catenatum from thre different countries Mar. Biol. 116, 471-476.

Price, C., Nasmyth, K. and Schuster, T. (1991) A general approach to the isolation of cell cycle-regulated genes in the budding yeast, Saccharomyces cerevisiae J. Ml. Biol. 218, 543-56.

Rizzo, P. J. (1981) Comparative aspects of basic chromatin proteins in dinoflagellates Biosys. 14, 433-443.

Rizzo, P. J. (1987) Biochemistry of the dinoflagellate nucleus. In The Biology of dinoflagellates, ed. Taylor, F. J. R., pp. 143-173. Blackwell Sci. Publ., Palo Alto, CA.

Rizzo, P. J. (1991) The enigma of the dinoflagellate chromosome J. Protozool. 38, 246-252.

Rizzo, P. J. and Morris, R. L. (1984) Some properties of the histone-like protein from Chrypthecodinium cohnii (HCc) Biosys. 16, 211-216.

Rodriguez, M., Cho, J. W., Sauer, H. W. and Rizzo, P. J. (1994) Evidence for the presence of $c d c 2$-like protein kinase in the dinoflagellate Cryptecodinium cohnii Journal of Eukaryotic Microbiology 40, 91-96.

Sako, Y., Kim, C. and Ishida, Y. (1992) Mendelian inheritance of paralytic shellfish poisoning toxin in the marine dinoflagellate Alexandrium catenella Biosc. Biotech. Biochem. 56, 692-694.

Sako, Y., Naya, N., Yoshida, T., Kim, C.-H., Uchida, A. and Ishida, Y. (1995) Studies on stability and heredety of PSP toxin composition in the toxic dinoflagellate Alexandrium. In Harmful Marine Algal Blooms, ed. Lassus, P., Arzul, G., Erard, E., Gentien, P. and Marcaillou, C., pp. 345-350. Lavoisier, Paris. 
Sala-Rovira, M., Geraud, M. L., Caput, D., Jacques, F., Soyer-Gobillard, M. O., Vernet, G. and Herzog, M. (1991) Molecular cloning and immunolocalization of two variants of the major basic nuclear protein $(\mathrm{HCc})$ from the histone-less eukaryote Crypthecodinium cohnii (Pyrrophyta) Chromosoma 100, 510-518.

Scholin, C. A., Hallegraeff, G. M. and Anderson, D. M. (1995) Molecular evolution of the Alexandrium tamarense 'species complex' (Dinophyceae): dispersal in the North American and West Pacific regions Phycol. 34, 472-485.

Sharma, Y. K. and Davis, K. R. (1995) Isolation of a novel Arabidopsis ozoneinduced cDNA by Differential Display Plant Mol. Biol. 29, 91-98.

Shimizu, Y. (1993) Microalgal metabolites Chem. Rev. 93, 1685-1698.

Shimizu, Y., Norte, M., Hori, A., Genenah, A. and Kobayashi, M. (1984) Biosynthesis of saxitoxin analogues: The unexpected pathway J. Amer. Chem. Soc. 106, 6433-6434.

Silva, E. S. and Sousa, I. (1981) Experimental work on the dinoflagellate toxin production Arq. Inst. Nacion. Saude (Portugal) VI, 381-387.

Tandeau de Marsac, N. and Houmard, J. (1993) Adaptation of cyanobacteria to environmental stimuli: New steps towards molecular mechanisms FEMS Microbiol. Rev. 104, 119-190.

Taroncher-Oldenburg, G., Kulis, D. M. and Anderson, D. M. (1997) Toxin variability during the cell cycle of the dinoflagellate Alexandrium fundyense $L \& O 42,1178-88$.

Triplett, E. L., Jovine, R. V. M., Govind, N. S., Roman, S. J., Chang, S. S. and Prézelin, B. B. (1993) Characterization of two full-length cDNA sequences encoding for apoproteins of peridinin-chlorophyll $a$-protein (PCP) complexes Molec. Mar. Biol. Biotech. 2, 246-254.

Utans, U., Liang, P., Wyne, L. R., Karnovsky, M. J. and Russell, M. E. (1994) Chronic cardiac rejection: Identification of five upregulated genes in transplanted hearts by differential mRNA display Proc. Natl. Acad. Sci. 91, 6463-6467.

van der Knaap, E. and Kende, H. (1995) Identification of a gibberellin-induced gene in deepwater rice using differential display of mRNA Plant Mol. Biol. 28, 589-592.

Van Dolah, F. M., Leighfield, T. A., Sandel, H. D. and Hsu, C. K. (1995) Cell division in the dinoflagellate Gambierdiscus toxicus is phased to the diurnal cycle and accompanied by activation of the cell cycle regulatory protein cdc2 kinase $J$. Phycol. 31, 395-400.

Wan, J. S., Sharp, S. J., Poirier, G. M.-C., Wagaman, P. C., Chambers, J., Pyati, J., Hom, Y.-L., Galindo, J. E., Huvar, A., Peterson, P. A., Jackson, M. R. and Erlander, M. G. (1996) Cloning differentially expressed mRNAs Nature Biotechnology 14, $1685-91$. 
Welsh, J., Chada, K., Dalal, S. S., Cheng, R., D., R. and McClelland, M. (1992) Arbitrarily primed PCR fingerprinting of RNA Nucleic Acids Res. 20, 4965-4970.

Wong, K. K. and McClelland, M. (1994) Stress-inducible gene of Salmonella typhimirium identified by arbitrarily primed PCR of RNA Proc. Natl. Acad. Sci. 91 , 639-643. 


\section{CONCLUSIONS}


The work described in this thesis has provided new insights into the cell cycle dynamics and the physiology of STX biosynthesis in the dinoflagellate Alexandrium fundyense. This was accomplished by combining a new approach, namely the study of toxigenesis in correlation to the cell cycle in synchronized cells, and the application of Differential Display to analyze differences in expressed mRNAs. In contrast to prior studies, this approach allowed the analysis of toxin production over short time intervals and relative to a well-defined cellular process, the cell cycle. It further allowed the identification of genes which had expression patterns related to toxigenic periods. Overall, this work has shown the potential of using traditional physiological techniques and molecular approaches to study the dynamics and the regulation of biochemical pathways in phytoplankton.

The first chapter presents the results from a study of toxigenesis in synchronized cultures of Alexandrium fundyense. For the first time it was possible to determine that toxin production is discontinuous and coupled to the $\mathrm{G}_{1}$ phase of the cell cycle. The differential accumulation of STX derivatives over time was also interpreted in terms of a possible sequence of interconversions among these compounds. I further demonstrated the existence of a discrete $\mathrm{S}$ phase and the presence of two transition points in the cell cycle of A. fundyense. These results implied cell cycle regulation of STX biosynthesis and a simple scheme of interconversions among STX derivatives.

Chapter II examines the effects of temperature and phosphate limitation on the coupling of STX biosynthesis to the $\mathrm{G}_{1}$ phase of the cell cycle. Over a range of growth rates and experimental treatments, toxin accumulation always correlated to increases in duration of $\mathrm{G}_{1}$. Therefore, and contrary to what had been previously suggested, toxin production rates were independent of the growth rate in A. fundyense. Differences in toxin composition between phophate-limited and nutrient-replete cultures were further interpreted to show that interconversions among STX derivatives by sulfatation reactions are not phosphate- 
dependent, while those mediated by oxidation reactions are inhibited by phosphate limitation.

In chapter III, Differential Display (DD) analysis of mRNA was used to identify genes that were up- or downregulated during the now well characterized periods of STX biosynthesis in synchronized cultures of $A$. fundyense. Three mRNAs were characterized and their expression patterns confirmed. This study further showed unequivocally that transcriptional regulation occurs in dinoflagellates, contrasting with previous suggestions that translational mechanisms might be the primary means of circadian regulation in these organisms. Despite the fact that none of the genes that were isolated was directly and exclusively related to toxigenesis, this work revealed the potential of using DD and other similar techniques for the identification of differentially expressed genes in dinoflagellates and phytoplankton in general.

Overall, this study clarifies several aspects of the biochemistry, physiology and regulation of STX biosynthesis and opens new paths for future research that I will present in detail now.

Biochemistry of STX biosynthesis. The main problem remaining to be solved in this field is the elucidation of the biosynthetic pathway of STX. The primary precursors, arginine, acetate and $S$-adenosylmethionine have been determined, but these, especially arginine, could be incorporated in a variety of ways which have yet to be determined. This has to happen at two levels: (1) determine the direct precursors or first intermediates leading to the synthesis of the STX backbone, and (2), establish the sequence of interconversions among STX derivatives. The first is the more difficult to address as it requires possible rethinking of the biogenetic pathway proposed by Shimizu and the development of alternative pathways that include all of the available information on precursor incorporation. 
Fig. 1 Proposed scheme of interconversions among STX derivatives. A putative origin is located around do-dc-STX, the simplest of all known derivatives (Broad arrows indicate proven conversions (refer to the INTRODUCTION); thin arrows denote putative reactions). 


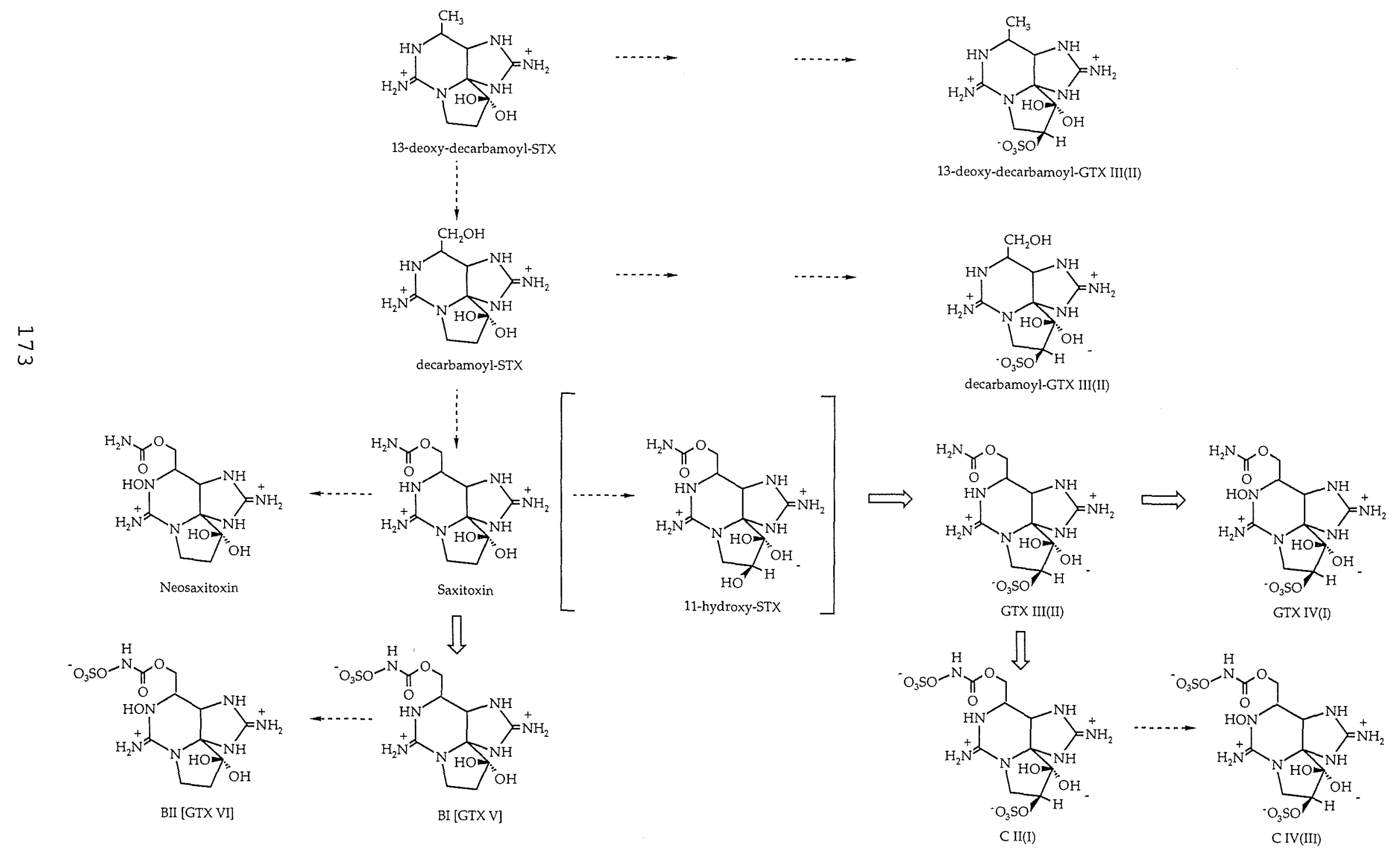


The recent isolation of simple derivatives of STX such as deoxy-decarbamoyl STX indicates that perhaps the first compounds produced by the biosynthetic pathway are centered around this kind of simple molecule. The breadth of information on toxin compositions and the few data available on enzymes that specifically catalyze some of the conversions also indicate that the first toxins to appear might be those of the STX series (no $\mathrm{OH}$ on $\mathrm{N}-1$ ). This hypothesis is supported by several facts: (1) No dc-NEO or dc-GTX I,IV has been isolated from any toxin synthesizing organism, (2) the two sulfatases so far described in the literature are specific for STX and GTX II,III, (3) the existence of a STXspecific oxidase/hydroxylase activity, (4) the selective increase of C I,II and GTX II,III under phosphate-limited conditions as described in chapter II and (5) the isolation of do-dcSTX and do-dc-GTX II, III but no do-dc-NEO or do-dc-GTX I,IV. The scheme of interconversions might be further simplified by the fact that $11-\beta$-epimers are possibly the only derivatives synthesized. All of the preceding information can be summarized in a scheme of interconversions in which the first compound is located somewhere in the 'structural' vicinity of do-dc-STX and the interconversions among the derivatives follow a few possible routes (Fig. 1). Only three classes of enzymes would be involved in this proposed pathway: (1) oxidases/hydroxylases for the oxydation of the do-dc-compounds and to generate the hydroxy- or NEO-series of toxins; (2) a carbamoyltransferase for the carbamoylation of the $\mathrm{C}-13$ residues; (3) sulfatases responsible for sulfatetransfers on two different positions of the derivatives. The question still remains open as to how exactly that first parent compound is synthesized and what its nature is.

Physiology of STX. One of the challenges in studying the physiology and dynamics of STX production is the fact that we still do not know the specifics of the biosynthetic pathway. This makes it difficult to interpret some of the information accumulated over the last decades. Very careful experiments describing the changes in toxicity in response to 
variations in the physico-chemical environment of the cells provide an insight into the effects of these environmental variables on toxigenesis, but the general nature of these factors and their broad influence on the cell's physiology make it hard to determine their mechanisms of action. This task is further complicated by the fact that regulation of toxin production might happen at many different levels, making it complicated to isolate the effect of single factors on its pathway. It will therefore be imperative in the future to learn more about the biosynthetic pathway in order to fully understand its regulation. One intriguing result presented in this thesis is related to the toxin production kinetics curve shown in the first chapter. The shape of this curve suggests the possibility of a biphasic kinetics pattern in which an initial burst in biosynthetic activity is followed by a steady state kinetics at a lower rate. Such dynamic patterns will be understood better once the actual enzymes responsible for STX production are isolated and purified.

Genetics and regulation of STX biosynthesis. This is still an unchartered territory. In chapter III of this thesis I proposed a new approach to the identification of genes related to STX biosynthesis based on the hypothesis that toxin production is cell cycle regulated and hence possibly regulated at the transcriptional level. This study showed the strengths and weaknesses of such an approach. As mentioned earlier, we still lack sufficient knowledge about the biosynthetic pathway to look for specific enzymes or genes. Blind approaches to the isolation of putative 'toxin' genes, such as the one described in this thesis, are hard because we still do not have the ideal system for singling out what makes toxic cells different from non-toxic ones. The use of synchronized cultures and the fact that toxin production is discontinuous represents a great leap forward. Future studies should probably also look at other organisms, specifically cyanobacteria, which are easier to manipulate genetically. Mating experiments between toxic and non-toxic strains of 
dinoflagellates also have the potential to tell us more about the genetics and inheritance of toxigenesis.

Differential Display and phytoplankton. This thesis also illustrates the potential of using comparative molecular techniques to study gene expression in organisms where standard genetic approaches are not applicable due to biological and physiscal constraints. The reaction of a microorganism to environmental stress could be monitored and specific genes isolated. I mentioned earlier that the study of regulation at the molecular level requires a good understanding of the biochemical mechanisms underlying a metabolic process. In cases such as nitrogen and phosphate depletion, quite a bit of information is available on the underlying mechanisms. This would make it simpler to design and subsequently interpret experiments where variations in the nutritional status are the only changing factor. For many such processes, transcriptional regulation is also the main means of regulation. Genes identified by DD or any of the other emerging molecular techniques that allow the identification of differentially regulated genes, could serve as markers for nutrient status of the cells or the environment. Molecular markers for pollution could also be developed in a similar way.

In conclusion, this thesis provides new insights on the cell cycle dynamics and the physiology of saxitoxin biosynthesis in the dinoflagellate Alexandrium fundyense. The correlation between these two processes has been characterized and several genes that are regulated in a similar cell cycle-dependent way were isolated. One of these genes, a putative histone-like protein, was analyzed in detail and constitutes an appendix to this thesis. A possible scheme of interconversion among STX derivatives is further proposed and the regulatory function of temperature and phosphate on STX biosynthesis were analyzed. Finally, future directions in the study of STX production are proposed that 
converge on one focal point: the primary importance to elucidate the sequence of steps of the STX biosynthetic pathway in order to understand the significance of this metabolic process for the producing organisms and its regulation, both, at the biochemical level and by the physico-chemical environment of the cell. 


\section{APPENDIX}

Cloning and characterization of a putative histone-like protein in Alexandrium fundyense (Dinophyceae) 


\section{ABSTRACT}

The biochemical characteristics of a putative basic histone-like protein (HAf) in the toxic dinoflagellate Alexandrium fundyense Balech and its expression pattern during the cell cycle were determined. HAf was first identified by Differential Display (DD) of mRNA applied to the analysis of synchronized cells of A. fundyense in different cell cycle stages. Several mRNAs expressed only at the beginning of the $\mathrm{G}_{1}$ phase of the cell cycle were cloned and used to screen an A. fundyense cDNA library. The deduced amino acid sequence of one of these bands corresponded to HAf. HAf is a basic protein with a $60 \%$ similarity with two histone-like proteins from the dinoflagellate Crypthecodinium cohnii Biecheler, was identified by screening an A. fundyense cDNA library. Several of its properties, such as a molecular weight of $9.3 \mathrm{kDa}$, a basicity of $24 \%$ and its amino acid composition, were comparable to those of two other dinoflagellates, C. cohnii and Oxyrrhis marina Dujardin. The predicted secondary structure, antigenicity and hydropathy profiles were analogous to those of two variants of histone-like proteins in C. cohnii. Moreover, induction of HAf was observed only at the beginning of the $\mathrm{G}_{1}$ phase of the cell cycle. This pattern of transcriptional regulation agreed with direct measurements of accumulation patterns of histone-like proteins in C. cohnii cultures. No defininte conclusions can be drawn about the function of this putative protein, but its similarity to other histone-like proteins, its basicity and its induction at the beginning of the $\mathrm{G}_{1}$ phase of the cell cycle, suggest that it could have a role in DNA structure determination or transcription initiation. 


\section{INTRODUCTION}

The distinct nature of the dinoflagellate nucleus is a well-documented phenomenon (reviewed Rizzo, 1987). Dinoflagellates represent the only group of eukaryotes lacking nucleosome structures and the associated histones (Bodansky et al., 1979; Herzog and Soyer, 1981). Other features include permanently condensed chomosomes, the presence of a nuclear membrane throughout the cell cycle and an extranuclear mitotic spindle (Kubai and Ris, 1969). These morphological characteristics had long been considered diagnostic of a primitive origin of the dinoflagellates that placed them somewhere intermediate between prokaryotes and 'true' eukaryotes (Dodge, 1965; Taylor, 1978). Only more recently has the phylogenetic position of the dinoflagellates been clarified through the analysis of large subunit rRNA and their origin placed closer to the emergence of other eukaryotes such as ciliates and yeasts (Lenaers et al., 1990).

In addition to the distinct morphological features described above, dinoflagellate nuclei also show several biochemical pecularities. The DNA composition is characterized by the presence of a modified base, 5-hydroxymethyluracil (HOMeU), that is not found in other eukaryotes (Rae, 1976). The presence of unusually high levels of DNA-bound metal elements, such as copper, iron, nickel and zinc, has been suggested to play a structural role in chromosomes (Sigee and Kearns, 1981). The existence of a distinct group of low molecular weight, basic proteins associated with nuclear DNA has also been reported (Rizzo, 1981). These proteins were termed 'histone-like' proteins because, like histones, they were localized in the nucleus and were associated with DNA, but showed less affinity for DNA and had compositional and biochemical differences relative to the five typical eukaryotic histones (Rizzo, 1985).

No definite role has been adscribed to histone-like proteins. Two non-exclusive hypotheses have been proposed: a structural role in DNA compaction and a regulatory 
function in DNA transcription (Sala-Rovira et al., 1991). Immunocytochemical studies of the Crypthecodinium cohnii histone-like protein, $\mathrm{HCc}$, have shown a homogeneous and close association of this protein with DNA during interphase and mitosis, suggesting organization or stabilization of chromosome structure (Géraud et al., 1991). HCc proteins also form intra- and/or intermolecular dimers via disulphide bridges between cysteines that could have a further DNA stabilizing role (Vernet et al., 1990). In view of the high degree of chromosomal complexity in dinoflagellates and their lack of regular eukaryotic chromosome organizers (nucleosomes) such a structural function is an attractive proposition.

A closer look at distribution patterns of $\mathrm{HCc}$ in chromosomes showed that although detectable over the entire structure, $\mathrm{HCc}$ was predominantly bound to extrachromosomal DNA loops (Géraud et al., 1991). Extrachromosomal DNA loops in dinoflagellates have been surmised to be the transcriptionally active regions of the chromosomes based on radioactive labeling experiments, the presence of Z-DNA and the detection of specific coding sequences in these regions (Sigee, 1984; Soyer-Gobillard et al., 1990; Anderson et $a l ., 1992)$. HCc has also been observed in nucleolar organizing regions, the sites where ribosomal transcription is initiated (Géraud et al., 1991). All this evidence suggests a possible role of these small basic peptides in transcription initiation or regulation.

Histone-like proteins from several dinoflagellates have been characterized with respect to amino acid composition and peptide mapping (Rizzo and Nooden, 1974; Jing-Yan, 1984; Rizzo et al., 1988; Sala-Rovira et al., 1991). Few data exist at the molecular level, as only two sequences of histone-like protein variants in Crypthecodinium cohnii have been determined so far (Sala-Rovira et al., 1991). Some information is also available on the temporal fluctuations of HCc over the cell cycle in C. cohnii (Géraud et al., 1991). In this report we describe a new putative histone-like protein from the thecate dinoflagellate 
Alexandrium fundyense. Expression patterns, sequence information and a comparative compositional and structural analysis with other histone-like proteins are presented.

\section{MATERIALS AND METHODS}

The organism. The toxic dinoflagellate Alexandrium fundyense (strain GtCA29) was used in this study. Cultures were maintained at $20^{\circ} \mathrm{C}$ in $\mathrm{f} / 2$ medium (Guillard and Ryther, 1962), modified by addition of $\mathrm{H}_{2} \mathrm{SeO}_{3}\left(10^{-8} \mathrm{M}\right)$ and by reducing the concentration of $\mathrm{CuSO}_{4}$ to $10^{-8} \mathrm{M}$. Irradiance of ca. $250 \mu \mathrm{Em}^{-2} \mathrm{~s}^{-1}$ was provided by cool white fluorescent bulbs on a 14:10 h light:dark cycle. Exponentially growing cultures (approx. 400 cells ml1) were synchronized by a dark induced block/release method, as previously described (Taroncher-Oldenburg et al., 1997). Samples for Differential Display (DD) analysis were drawn at different times of the cell cycle: once at the beginning and once at the end of the $\mathrm{G}_{1}$ cell cycle phase, once at the peak of the $S$ phase and a last time during $\mathrm{G}_{2}$ (Fig. 1). The mRNA fractions were purified and analyzed by DD as reported elsewhere (Chapter III).

cDNA Library Screening. DD probes for screening the library were obtained by labeling the cloned cDNA of interest with Digoxigenin-11-dUTP (Genius Nonradioactive Nucleic Acid Labeling and Detection System, Boehringer Mannheim, IN) and hybridizations were conducted overnight as previously described (Chapter III). Positive plaques were then excised in vivo, cloned and sequenced following the manufacturer's protocols (ZAP-cDNA cloning kit, Stratagene).

RNA Analysis. RNA dot blot analysis were performed as described elsewhere (Chapter III). For the RNA Northern analysis, ten $\mu \mathrm{g}$ of total, DNAse treated RNA 
Figure 1 Cell cycle dynamics in synchronously growing Alexandrium fundyense. Lines show relative distributions of cells in the different cell cycle stages $\left(\mathrm{G}_{1},-\mathbf{-}-; \mathrm{S}\right.$, - - and $\mathrm{G}_{2}+\mathrm{M},-\boldsymbol{-}$ ). Arrows denote sampling points for the Differential Display analysis protocol: Two during $\mathrm{G}_{1}$, (I) early and (II) late segments, one during the $\mathrm{S}$ phase (III) and a last one during $\mathrm{G}_{2}$ (IV). Shaded areas correspond to the dark periods of the 14:10 hour light:dark cycle under which A. fundyense was synchronized. 


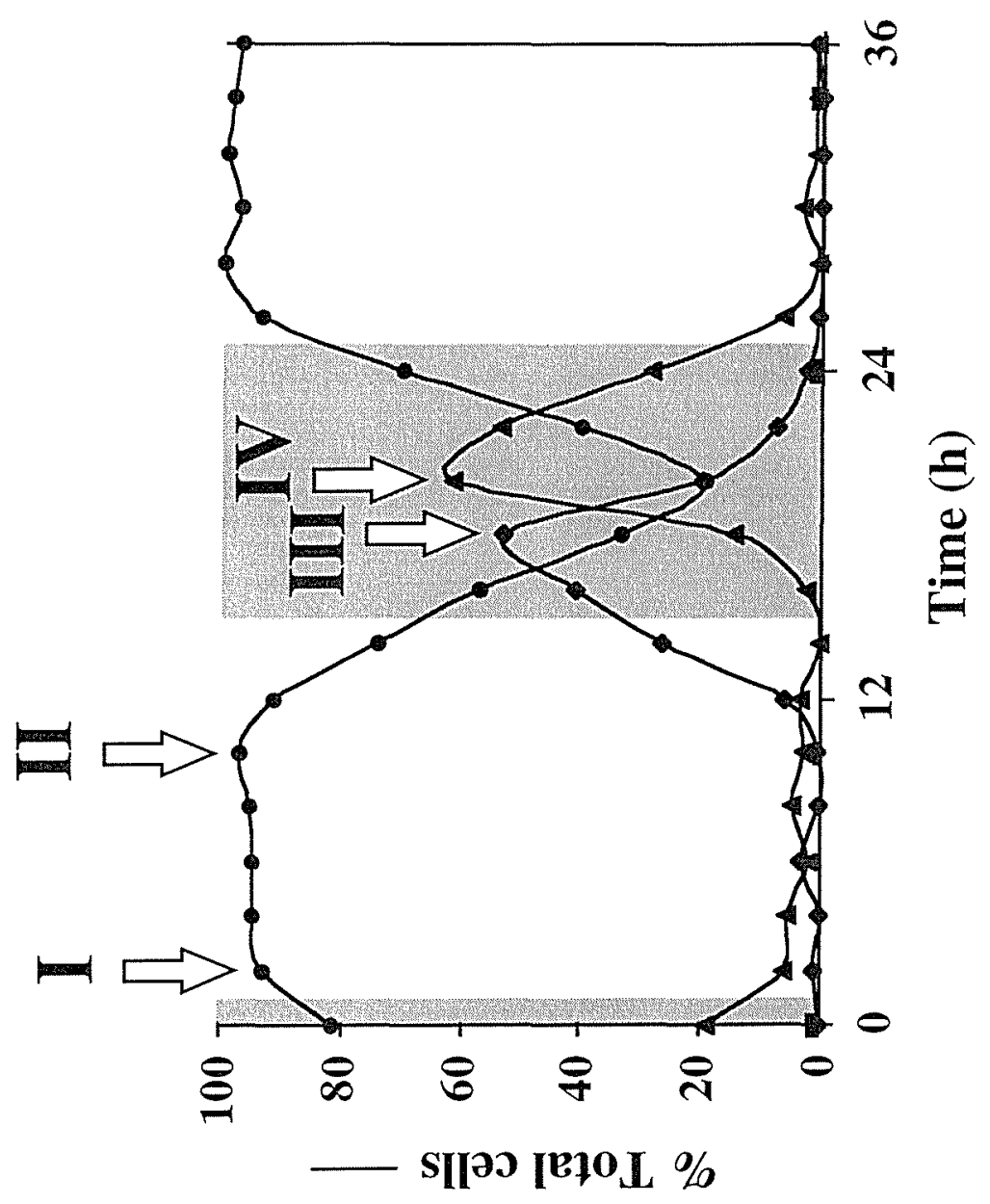


representing each of the four cell cycle stages described above were loaded on a formaldehyde gel, run at a constant intensity of $5 \mathrm{~V} / \mathrm{cm}$ in MOPS running buffer and transferred overnight to positively charged nylon membranes (Boehringer Mannheim, IN). The histone-like specific probe obtained from the DD analysis was labeled as described above. Hybridizations were performed overnight in high SDS buffer, as recommended by the manufacturer, and at $42^{\circ} \mathrm{C}$ (Genius Nonradioactive Nucleic Acid Labeling and Detection System, Boehringer Mannheim, IN).

Sequence Analysis. The nucleotide sequence was compared to the non-redundant GenBank, EMBL, DDBJ and PDB sequence databases using the Basic Local Alignment Search Tool program (BLAST) in its version for nucleotides (BLASTN) or aminoacids (BLASTX) (Altschul et al., 1990). The corresponding amino acid sequence was predicted using the universal genetic code. The deduced protein sequence was further characterized with the sequence analysis software program MacVector (Oxford Molecular Limited). Secondary structures were determined by the Robson-Garnier method (Garnier et al., 1978), and antigenicity and hydropathy profiles were calculated following standard procedures (Kyte and Doolittle, 1982; Jameson and Wolf, 1988).

\section{RESULTS}

In a previous study targeting the identification of up- and downregulated genes during toxigenesis in the toxic dinoflagellate Alexandrium fundyense, a gene for a putative histone-like protein was isolated (Chapter III). The Differential Display pattern of this protein showed accumulation of the corresponding mRNA at the beginning of $\mathrm{G}_{1}$ (Fig. 2A), a pattern that was confirmed by total RNA dot blot analysis (Fig. 2B) and by 
Northern blot analysis (Fig. 2C). The DD probe hybridized to a band corresponding to a size of approximately 600 base pairs (Fig. 2C). The corresponding cDNA rescued from an A. fundyense cDNA library contained 577 nucleotides and an open reading frame (ORF) of 255 nucleotides or the equivalent of 85 aa (Chapter III). The database search aligned this sequence to two histone-like proteins from Crypthecodinium cohnii Biecheler. The combined similarity was $60 \%$, with each of the two different histone-like proteins showing a similarity of $52 \%$ and a homology of $35 \%$. No significant similarities to other proteins were found.

The inferred protein has a molecular weight of approximately $9.3 \mathrm{kDa}$. Amino acid composition and other characteristics of this protein were analyzed by comparison with three histone-like proteins from different dinoflagellates (Table 1; Fig. 3). Two indicators of basicity were calculated: (1) the fraction of basic amino acids (Arg, Lys) per protein, which was remarkably high at about $24 \%$ and conserved among the four proteins, and (2), the ratio of basic to acidic amino acids ((Arg, Lys)/(Gln, Glu, Asp, Asn)), which was the same for HAf and one of the Crypthecodinium cohnii proteins and approximately 2.5 times lower for the second C. cohnii protein and the Oxyrrhis marina Dujardin protein (Table 1). Even though the compositional analysis of all four proteins revealed a high degree of similarity among them, a few differences are apparent: The Lys to Arg ratio shows a high inter- and intraspecific variability (Fig. 3; Table 1); two cysteine residues are clearly present only in $\mathrm{HAf}$ and in $\mathrm{HCc} 1$, while only trace levels have been reported for $\mathrm{HCc}$ and $\mathrm{HOm}$ (Fig. 3); the high percentage of methionine residues in $\mathrm{HCc1}$ corresponds to eight residues on the protein while $\mathrm{HAf}, \mathrm{HCc}$ and $\mathrm{HOm}$ only contain one methionine or none. In a separate analysis, it was determined that in contrast to the two deduced protein variants from $C$. cohnii and the amino-terminal of a third peptide, also an $\mathrm{HCc}$ protein, HAf only contains one methionine in the NH2-region, while the other three peptides contain between three and six methionine residues (Fig. 4). 
Figure 2. Expression of HAf. (A) Differential Display (DD) analysis of Alexandrium fundyense in early and late $G_{1}, S$ phase and $G_{2}$ (arrow points at HAf; numerals I through IV refer to sampling points in Fig. 1; double lanes represent duplicate RT-PCRs). (B) Confirmation of DD pattern by total RNA dot blot analysis. (C) RNA blot analysis (Northern) confirming the induction of the histone-like protein (HAf) in Alexandrium fundyense during $\mathrm{G}_{1}$ (RNA loading was evaluated by ethidium bromide staining and identification of the $18 \mathrm{~S}$ and $28 \mathrm{~S}$ rRNA bands (bottom)). 


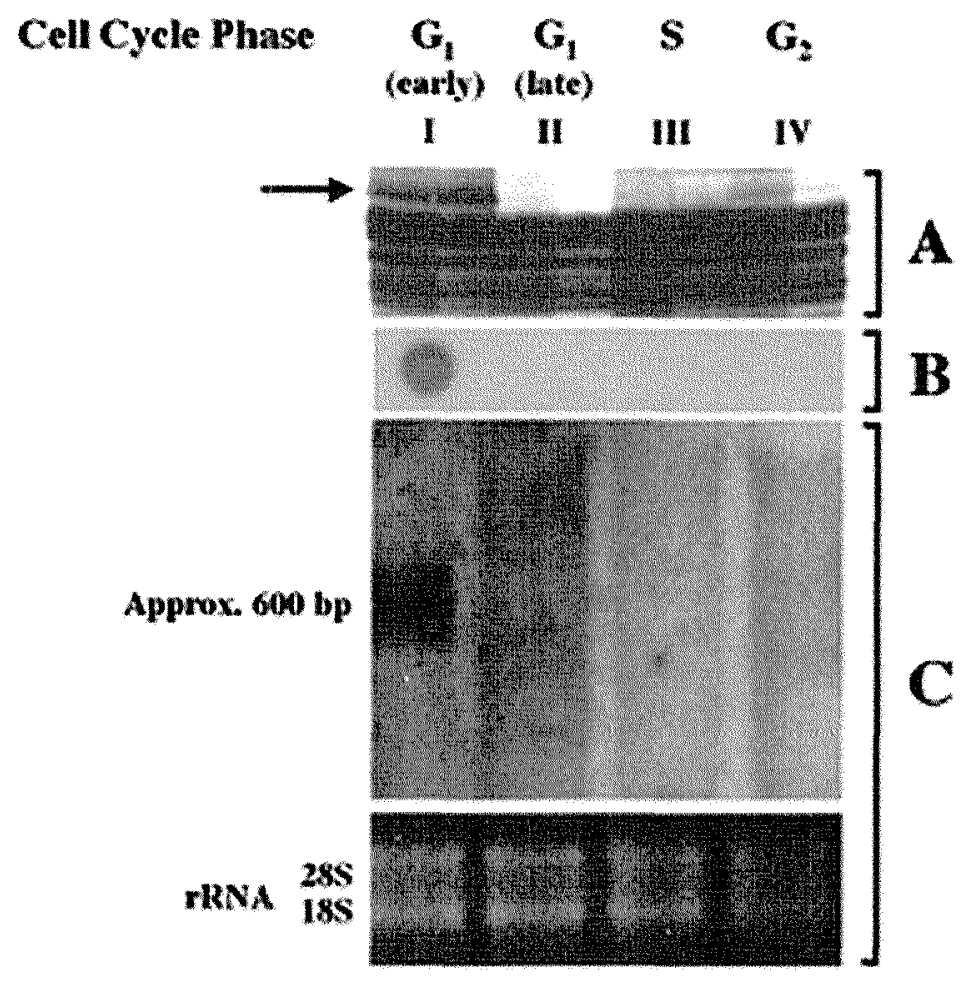


Table 1. $\quad$ Properties $^{\mathrm{a}}$ of histone-like proteins from several dinoflagellates

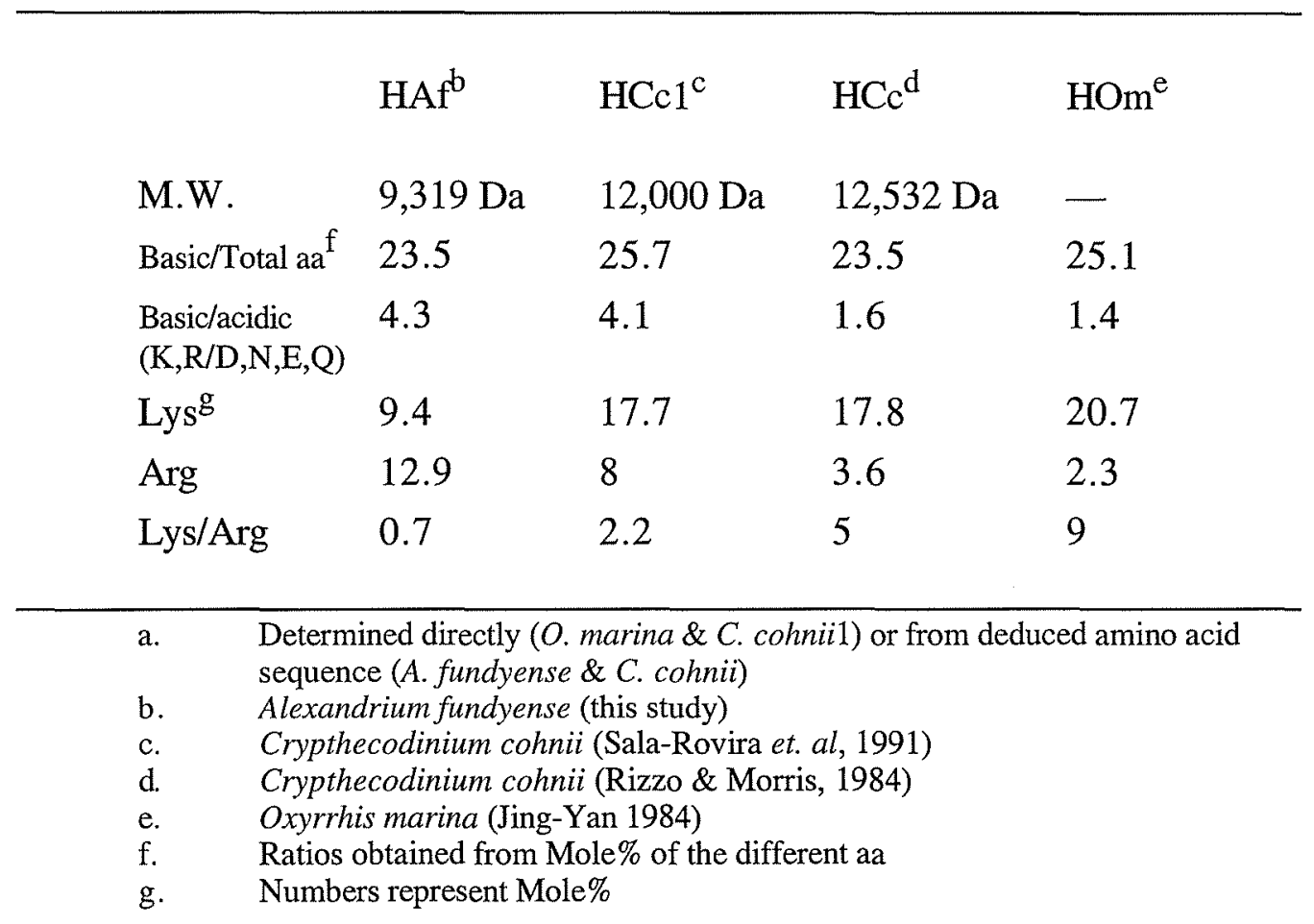


Figure 3. Amino acid compositions of histone-like proteins from several dinoflagellates (Asx and Glx refer to Asp and Asn, and Glu and Gln, respectively). 


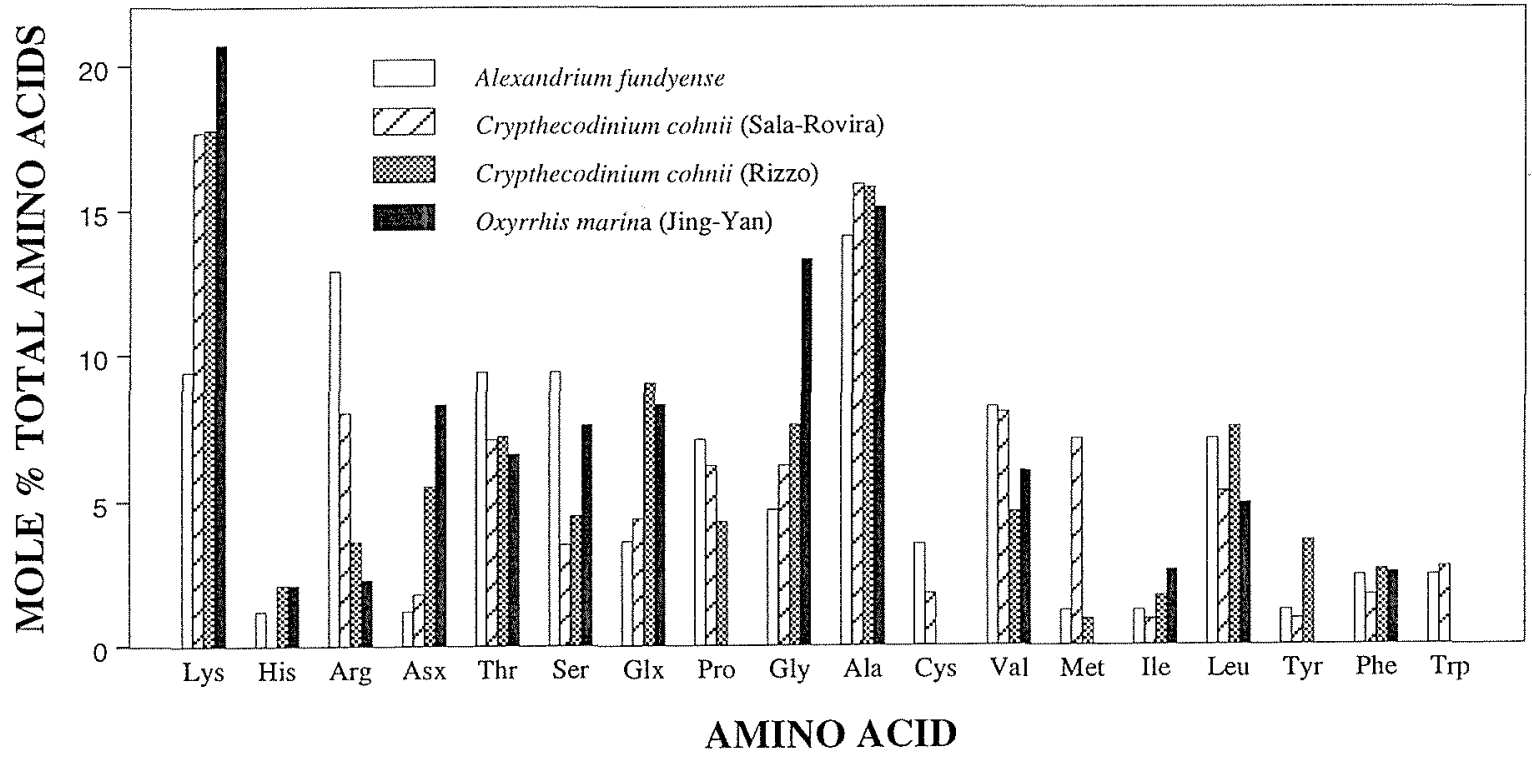


Figure 4. Alignment of the NH2-terminals of HAf, $\mathrm{HCc} 2, \mathrm{HCc}$ and $\mathrm{HCc} 1$ (Stars denote gaps; Met residues are underlined). The HAf, $\mathrm{HCc} 1$ and $\mathrm{HCc} 2$ peptide sequences are inferred from the cloned cDNA and $\mathrm{HCc}$ was determined directly from a peptide. 

A. fundyense
MSPSAT
C. cohnii2
$\underline{\underline{M K A M K A}} \stackrel{\underline{\underline{M}}}{=} * * \mathrm{TKKAMT}$
$\mathrm{HCC}$
PKMKAAMKATMKAMKA $\underline{\underline{\underline{M}}}=$
C. cohnii1
$\underline{\underline{M A P K M K A A}} \stackrel{=}{=} * *$ MKAMKAPAMKGKAMT 
Figure 5. Hydropathy profiles of the histone-like proteins $\operatorname{HAf}(\mathbf{A}), \operatorname{HCc} 2(\mathbf{B})$ and $\mathrm{HCc} 1(\mathbf{C})$. The proteins are positioned relative to each other according to their sequence alignment. Positive values indicate hydrophylicity and negative values hydrophobicity. Numerals $\mathbf{I}$ through $\mathbf{V}$ indicate regions of structural and/or sequence similarity among proteins (see text for details). $\mathrm{NH}_{2}$ and $\mathrm{COOH}$ denote, respectively, the amino and carboxy terminals of the proteins. The dotted lines frame the smallest of the three proteins, HAf. The length of the black bar represents 20 aa on the abscissa. 


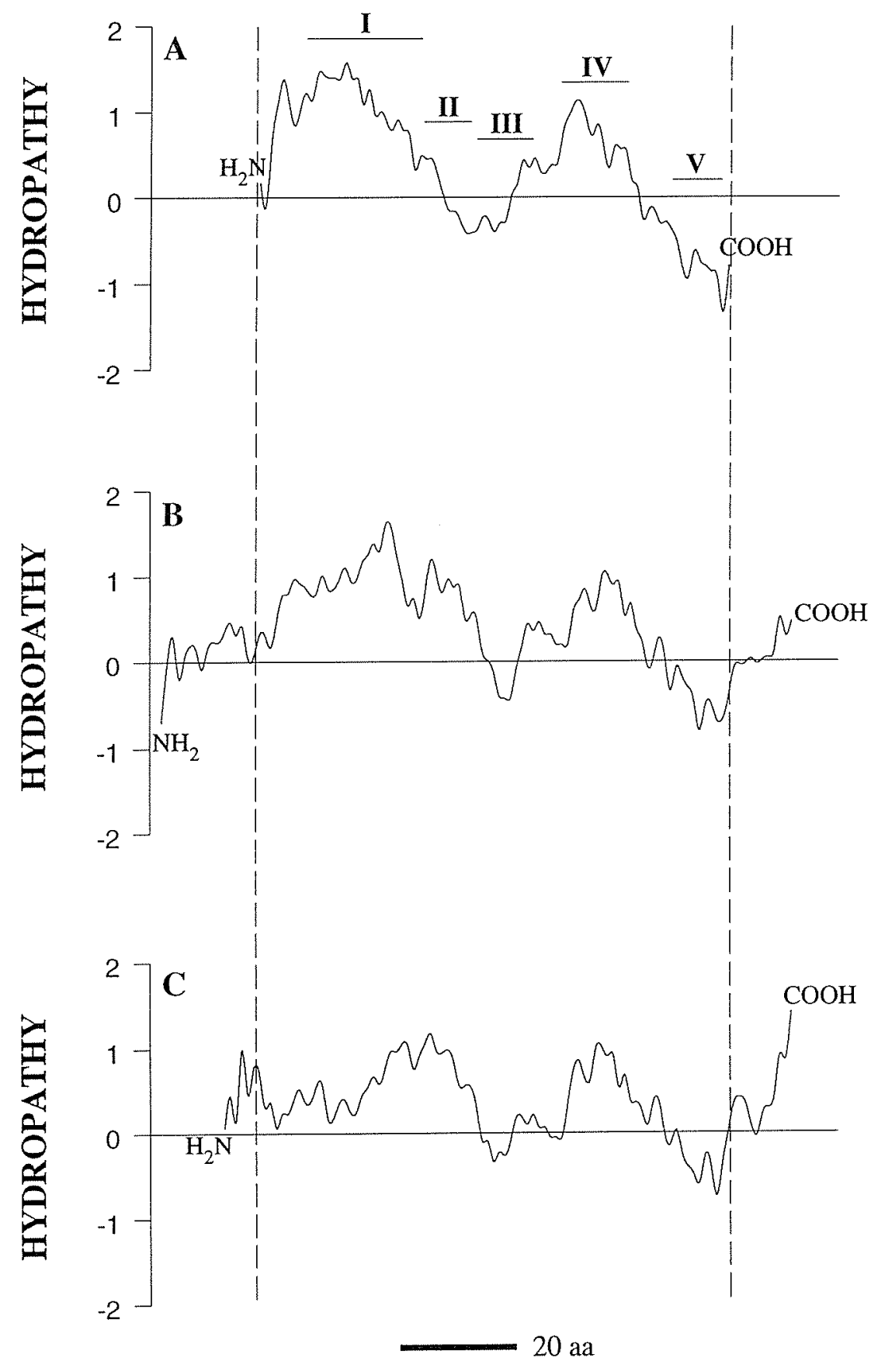


Predictions of the secondary structure as well as antigenic index and hydropathy profiles were obtained for $\mathrm{HAf}, \mathrm{HCc} 1$ (a) and $\mathrm{HCc}(\mathrm{b})$. Five distinct regions could be defined. These domains are plotted on the hydropathy profiles (Fig. 5). The hydropathy profiles revealed an overlapping pattern of alternating hydrophylicity and hydrophobicity among the three proteins. Region I (HAf aa 14-33) is characterized by high sequence variability among the three proteins. Structurally, it is defined by a succession of $\beta$-sheets and the highest hydrophylicity within each of the proteins. Region II (Haf aa 35-42) is highly conserved and of varying hydropathy among the three proteins. It represents the transition to region III (HAf aa 43-52), a very hydrophobic region with $\beta$-sheet configuration in the middle of all three proteins. In all three cases this region also shows the lowest antigenicity index of the entire protein. Region IV (HAf aa 54-65) is again highly conserved and very hydrophylic. The carboxy-end, region $\mathbf{V}$ (Haf aa 75-83), is hydrophobic and has a low antigenicity index. Region $V$ is constituted of an $\alpha$-helix. The carboxy-terminal portions of $\mathrm{HCc} 1$ and $\mathrm{HCc} 2$ not overlapping with $\mathrm{HAf}$ consist of hydrophylic $\beta$-sheets.

\section{DISCUSSION}

Isolation of a putative histone-like protein in Alexandrium fundyense. Differential Display analysis of different cell cycle stages and levels of toxigenicity in A. fundyense resulted in the identification of a putative histone-like protein. Differential Display is a genetic technique that allows the identification of transcriptionally regulated genes in eukaryotes (Liang and Pardee, 1992). It is based on an RT-PCR (reverse transcription -

polymerase chain reaction) approach and the usage of primers that specifically amplify mRNA. Differential Display is highly sensitive and reproducible and has been successfully 
used to identify developmentally and environmentally regulated genes in a variety of organisms (Utans et al., 1994; Abrahamsen et al., 1995; Sharma and Davis, 1995; van der Knaap and Kende, 1995; Wan et al., 1996).

Toxigenesis in synchronized cultures of Alexandrium fundyense is circumscribed to a period of 8 to 10 hours at the beginning of the $G_{1}$ phase of the cell cycle (TaroncherOldenburg et al., 1997). In an effort to identify genes that were up- or downregulated during those periods of toxin biosynthesis, we analyzed the mRNA populations of cells that were: (1) in $G_{1}$ and producing toxin; (2) in $G_{1}$ and not producing toxin; (3) in the $S$ phase; and (4) in $\mathrm{G}_{2}$ (Fig. 1) (Chapter III). As a result of this experimental design, we expected to isolate not only cDNAs of genes that were putatively related to STX biosynthesis, but also cDNAs of genes that might bear some relation to the beginning of the $\mathrm{G}_{1}$ cell cycle phase of $A$. fundyense. One of the bands we identified rescued a full-length cDNA with a similarity of $60 \%$ at the amino acid level with histone-like proteins from the dinoflagellate Crypthecodinium cohnii (Chapter III).

The identification and characterization of this putative histone-like protein is significant because molecular information is scarce on this family of dinoflagellate proteins. Comparative biochemical and structural analysis of the $A$. fundyense protein with several histone-like proteins from other dinoflagellates also sheds new light onto our understanding of their possible structure-function relationships.

Characterization of HAf. Histone-like proteins are defined by several characteristics: Low molecular weight, high basicity, low protein to DNA ratio and their affinity for DNA (Rizzo, 1985). They share some of these properties with the 'true' histones but still form a class by themselves as their molar ratio with DNA is typically about $20 \%$ or less (while true histones tend to be in equimolar concentrations with DNA) and have an affinity for DNA that is significantly less than that of histones (Rizzo, 1985). The five different types of 
histones characterized in eukaryotes are highly conserved, both in sequence and in structure, while histone-like proteins are much more variable. 'True' histones have very well defined histone-histone binding sites that are not present in histone-like proteins (Rizzo, 1985). Inter- and intramolecular binding sites in histone-like proteins have been suggested to be related to the presence of cysteine residues in the molecule (Vernet et al., 1990).

Histone-like proteins from several dinoflagellates have been characterized using electrophoresis, peptide mapping and amino acid analysis (Jing-Yan, 1984; Rizzo and Morris, 1984) (reviewed Rizzo, 1987). Only two complete histone-like protein sequences and one amino-terminal peptide have been reported in the literature (Sala-Rovira et al., 1991). A remarkably conserved characteristic of these proteins is their high basicity (approximately 24\%) which is responsible for their DNA affinity (Table 1). Other characteristics such as the ratio of basicity to acidity show a wide range and tell us more about the kind of variations to expect among this class of proteins. For instance, the two C. cohnii proteins, $\mathrm{HCc} 1$ and $\mathrm{HCc}$, show a high disparity in this latter parameter and exhibit respectively more similarity to HAf or HOm (Table 1). The amino acid compositions are a further example for inter- and intraspecific variations superimposed over a pattern of analogous functionalities (Fig. 3). It is of interest to notice the antiparallel distributions of the main basic amino acids, Arg and Lys (Fig. 3; Table 1). These patterns, resulting in the highly conserved basicity of the protein, the main characteristic of these molecules, suggest a low evolutionary pressure on the actual composition of the proteins but a very high pressure on their functional basicity. Comparative studies of their peptide maps and electrophoretic mobilities have also shown that these proteins are less conserved than the equivalent set of histones in other eukaryotes (Rizzo and Morris, 1984).

The molecular weights of histone-like proteins range from approx. $10 \mathrm{kDa}$ to about 17 $\mathrm{kDa}$ with two exceptions in $C$. cohnii, where in addition to six low molecular weight 
proteins, two basic proteins of high molecular weight (45 and $50 \mathrm{kDa}$ ) have been characterized (Vernet et al., 1990). The deduced amino acid sequence we report in this paper gives a molecular weight of approximately $9.3 \mathrm{kDa}$ to HAf, thereby becoming the smallest such protein described in the literature. Insufficient sequence information is available to allow for a comprehensive analysis of size, structure and functionality of these proteins, but one interesting issue was raised by the analysis of the amino terminals of the two variants $\mathrm{HCc} 1$ and $\mathrm{HCc} 2$ (Sala-Rovira et al., 1991). The high content in methionine residues observed in the first ten to twenty aminoacids suggested the possibility of multiple or alternative transcription initiation sites that could cause significant variations in the size of these proteins (Fig. 4). In contrast, the amino-terminal of HAf only contains one methionine residue that aligns with aa 17 of $\mathrm{HCc} 1$ and aa 6 of $\mathrm{HCc} 2$ (Fig. 4). Synthesis of peptides with different sizes from the same mRNA template has been recently described for the luciferin-binding protein from Gonyaulax polyedra (Mittag et al., 1997). In this case it was shown that the synthesis of two LBP variants of different length was due to translational initiation at two different AUG codons (Met residues) located within the 5'end of the same ORF. Such a mechanism could be involved in the synthesis of the different HCc variants that have been biochemically characterized in Crypthecodinium cohnii (Vernet et al., 1990; Sala-Rovira et al., 1991).

Despite their size differences, the three proteins exhibit remarkably similar hydropathy and antigenicity profiles (Fig. 5). The core structure consists of one small and highly hydrophobic region flanked by two larger and very hydrophylic domains This overlap in molecular characteristics might relate to the function of these proteins. More sequence information of other histone-like proteins is needed to determine if indeed their DNA binding properties are related to that specific configuration. Predictions of the secondary structures, though consistent, should still only be considered suggestive of the true structures because of a lack of supporting structural data (Nishikawa, 1983). 
Expression of HAf. Immunocytochemical studies to elucidate the distribution of the DNA-binding protein HCc during the cell cycle of Crypthecodinium cohnii revealed a close association between the protein and nucleofilaments as well as extrachromosomal loops of DNA (Géraud et al., 1991). Constant labelling throughout interphase as well as the different stages of mitosis suggests new supply of protein at either the very end of the mitotic process or the beginning of $\mathrm{G}_{1}$ (Géraud $e t$ al., 1991). Our results with DD and their confirmation by Northern blotting (Fig. 2C) show clear induction of HAf expression at the start of the $\mathrm{G}_{1}$ phase of the cell cycle, corroborating the prior observations on $C$. cohnii. Other cell cycle-dependent genes have been shown to be transcriptionally regulated in eukaryotes (Price et al., 1991). Some histones are also induced in proliferating cells (Callard and Mazzolini, 1997). We conclude that histone-like proteins are closely associated with DNA and their expression is regulated in a cell cycle dependent way. 


\section{REFERENCES}

Abrahamsen, M. S., Johnson, R. R., Hathaway, M. and White, M. W. (1995) Identification of Eimeria bovis merozoite cDNAs using differential mRNA display. Mol. Biochem. Parasitol. 71, 183-191.

Altschul, S. F., Gish, W., Miller, W., Myers, E. W. and D.J., L. (1990) Basic local alignment search tool. J. Mol. Biol. 215, 403-10.

Anderson, D. M., Grabher, A. and Herzog, M. (1992) Separation of coding sequences from structural DNA in the dinoflagellate Crypthecodonium cohnii. Molec. Mar. Biol. Biotech. 1, 89-96.

Bodansky, S., Mintz, L. B. and Holmes, D. S. (1979) Th mesocaryote Gyrodinium cohnii lacks nucleosomes. Biochem. Biophys. Res. Commun. 88, 1329-1336.

Callard, D. and Mazzolini, L. (1997) Identification of proliferation-induced genes in Arabidopsis thaliana. Characterization of a new member of the highly evolutionarily conserved histone H2A.F/Z variant subfamily. Plant Physiol. 115, 1385-95.

Dodge, J. D. (1965) Chromosome structure in the dinoflagellates and the problem of the mesocaryotic cell. Excerpta Med. Int. Congr. Ser. 91, 339-341.

Garnier, J., Osguthorpe, D. J. and Robson, B. (1978) Analysis of the accuracy and implications of simple methods for predicting the scondary structure of globular proteins. J. Mol. Biol. 120, 97-120.

Géraud, M.-L., Herzog, M. and Soyer-Gobillard, M. O. (1991) Nucleolar localization of rRNA coding sequences in Prorocentrum micans Ehr. (Dinomastigote, kingdom protoctista) by in situ hybridization. BioSystems 26, 61-74.

Guillard, R. R. L. and Ryther, J. H. (1962) Studies of marine phytoplanktonic diatoms. Cyclotella nana Hustedt and Detonula confervacea (Cleve) Gran. Can. J. Microbiol. 8, 229-239.

Herzog, M. and Soyer, M. O. (1981) Distinctive features of dinoflagellate chromatin. Absence of nucleosomes in a primitive species, Prorocentrum micans E. Eur. J. Cell. Biol. 23, 295-302.

Jameson, B. A. and Wolf, H. (1988) The antigenic index: A novel algorithm for predicting antigenic determinants. Comput. Applic. Biosciences 4, 181-86.

Jing-Yan, L. (1984) Studies on dinoflagellate chromosomal basic protein. BioSystems 16, 217-225.

Kubai, D. F. and Ris, H. (1969) Division in the dinoflagellate Gyrodinium cohnii (Schiller). A new type of nuclear reproduction. J. Cell Biol. 40, 508-528. 
Kyte, J. and Doolittle, R. F. (1982) A simple method for displaying the hydropathic character of a protein. J. Mol. Biol. 157, 105-132.

Lenaers, G., Scholin, C., Bhaud, Y., Saint-Hilaire, D. and Herzog, M. (1990) A molecular phylogeny of dinoflagellate protists (Pyrrhophyta) inferred from the sequence of 24S rRNA divergent domains D1 and D8. J. Mol. Evol. 32, 53-63.

Liang, P. and Pardee, A. B. (1992) Differential display of eukaryotic messenger RNA by means of the polymerase chain reaction. Science 257, 967-971.

Mittag, M., Eckerskorn, C., Strupat, K. and Hastings, J. W. (1997) Differential translational initiation of $\mathrm{lbp}$ mRNA is caused by a 5 upstream open reading frame. FEBS Lett. 411, 245-250.

Nishikawa, K. (1983) Assesment of secondary structure prediction of proteins. Biochim. Biophys. Acta 748, 285-299.

Price, C., Nasmyth, K. and Schuster, T. (1991) A general approach to the isolation of cell cycle-regulated genes in the budding yeast, Saccharomyces cerevisiae. J. Ml. Biol. 218, 543-56.

Rae, P. M. M. (1976) Hydroxymathyluracil in eukariotic DNA: A natural feature of the pyrrophyta (dinoflagellates). Science 194, 1062-1064.

Rizzo, P. J. (1981) Comparative aspects of basic chromatin proteins in dinoflagellates. BioSystems 14, 433-443.

Rizzo, P. J. (1985) Histones in protistan evolution. BioSystems 18, 249-262.

Rizzo, P. J. (1987) Biochemistry of the dinoflagellate nucleus. In The Biology of dinoflagellates, ed. F. J. R. Taylor, pp. 143-173. Blackwell Sci. Publ., Palo Alto, CA.

Rizzo, P. J. and Morris, R. L. (1984) Some properties of the histone-like protein from Chrypthecodinium cohnii (HCc). BioSystems 16, 211-216.

Rizzo, P. J., Morris, R. L. and Zweidler, A. (1988) The histones of the endosymbiont alga of Peridinium balticum (Dinophyceae). BioSystems 21, 231-238.

Rizzo, P. J. and Nooden, L. D. (1974) Partial characterization of dinoflagellate chromosomal proteins. Biochim. Biophys. Acta 349, 415-427.

Sala-Rovira, M., Geraud, M. L., Caput, D., Jacques, F., Soyer-Gobillard, M. O., Vernet, G. and Herzog, M. (1991) Molecular cloning and immunolocalization of two variants of the major basic nuclear protein $(\mathrm{HCc})$ from the histone-less eukaryote Crypthecodinium cohnii (Pyrrophyta). Chromosoma 100, 510-518.

Sharma, Y. K. and Davis, K. R. (1995) Isolation of a novel Arabidopsis ozone-induced cDNA by Differential Display. Plant Mol. Biol. 29, 91-98. 
Sigee, D. and Kearns, L. P. (1981) Levels of dinoflagellate chromosome-bound metals in conditions of low external ion availability: An X-ray microanalytical study. Tissue \& Cell 13, 441-451.

Sigee, D. C. (1984) Structural DNA and genetically avtive DNA in dinoflgellate chromosomes. BioSystems 16, 203-210.

Soyer-Gobillard, M. O., Géraud, M. L., Coulaud, D., Barray, M., Théveny, B., Révet, B. and Delain, E. (1990) Location of B- and Z-DNA in the chromosome of a primitive eukaryote dinoflagellate. J. Cell. Biol. 111, 293-308.

Taroncher-Oldenburg, G., Kulis, D. M. and Anderson, D. M. (1997) Toxin variability during the cell cycle of the dinoflagellate Alexandrium fundyense. Limnol. Oceanogr. 42, 1178-88.

Taylor, F. J. R. (1978) Problems in the development of an explicit hypothetical phylogeny of the lower eukaryotes. BioSystems 10, 67-89.

Utans, U., Liang, P., Wyne, L. R., Karnovsky, M. J. and Russell, M. E. (1994) Chronic cardiac rejection: Identification of five upregulated genes in transplanted hearts by differential mRNA display. Proc. Natl. Acad. Sci. USA 91, 6463-6467.

van der Knaap, E. and Kende, H. (1995) Identification of a gibberellin-induced gene in deepwater rice using differential display of mRNA. Plant Mol. Biol. 28, 589-592.

Vernet, G., Sala-Rovira, M., Maeder, M., Jacques, F. and Herzog, M. (1990) Basic nuclear proteins of the histone-less eukaryote Crypthecodinium cohnii (Pyrrhophyta): two dimensional electrophoresis and DNA-binding properties. Biochim. Biophys. Acta 1048, 281-289.

Wan, J. S., Sharp, S. J., Poirier, G. M.-C., Wagaman, P. C., Chambers, J., Pyati, J., Hom, Y.-L., Galindo, J. E., Huvar, A., Peterson, P. A., Jackson, M. R. and Erlander, M. G. (1996) Cloning differentially expressed mRNAs. Nature Biotechnology 14, 1685-91. 